Prepared in cooperation with the Miami-Dade Water and Sewer Department and the Department of Environmental Resources Management

Occurrence and Potential Transport of Selected Pharmaceuticals and Other Organic Wastewater Compounds from Wastewater-Treatment Plant Influent and Effluent to Groundwater and Canal Systems in Miami-Dade County, Florida
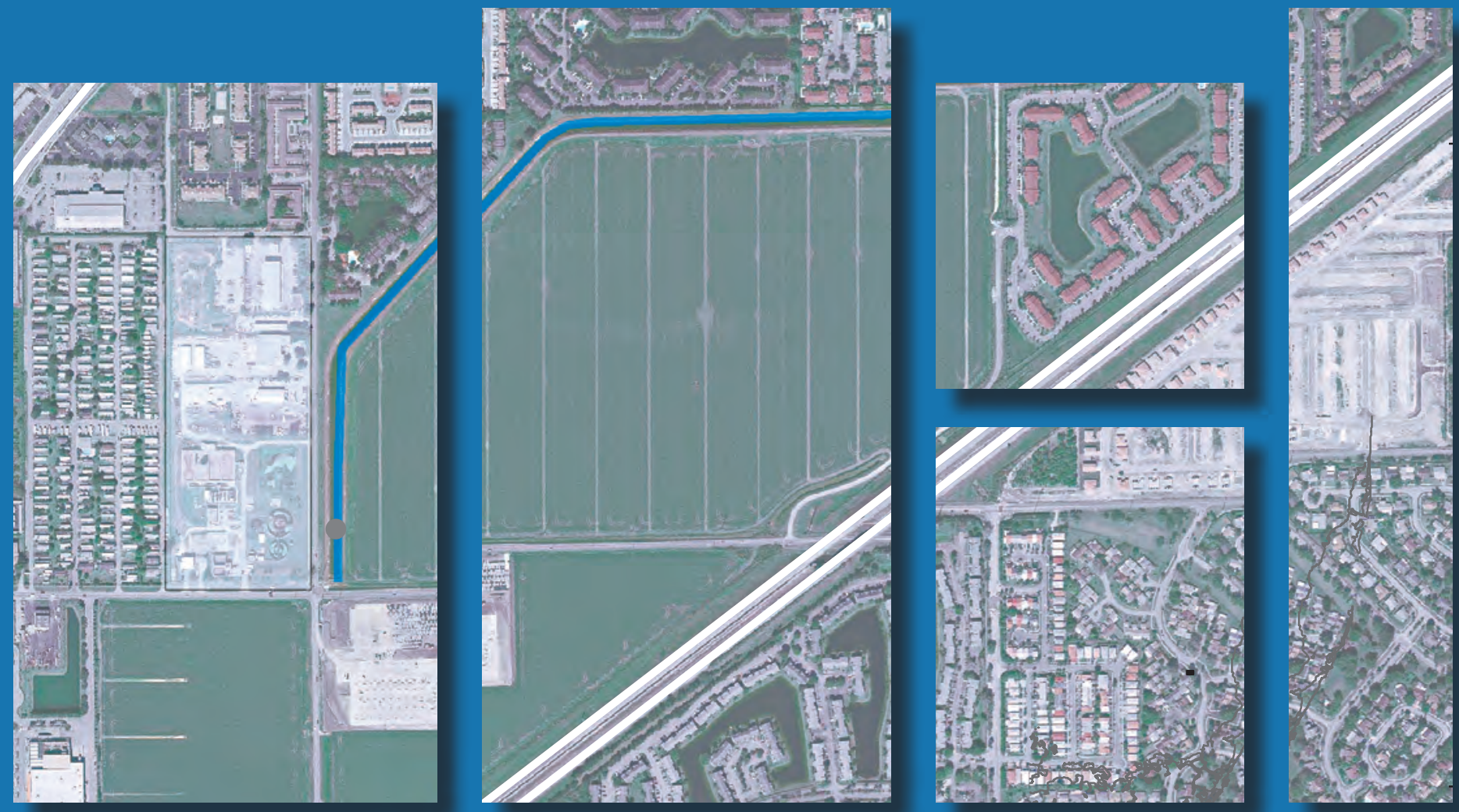

Scientific Investigations Report 2012-5083 



\section{Occurrence and Potential Transport of Selected Pharmaceuticals and Other Organic Wastewater Compounds from Wastewater-Treatment Plant Influent and Effluent to Groundwater and Canal Systems in Miami-Dade County, Florida}

By Adam L. Foster, Brian G. Katz, and Michael T. Meyer

Prepared in cooperation with the Miami-Dade Water and Sewer Department and the Department of Environmental Resources Management

Series Name 2012-5083 


\section{U.S. Department of the Interior \\ KEN SALAZAR, Secretary \\ U.S. Geological Survey \\ Marcia K. McNutt, Director}

\section{U.S. Geological Survey, Reston, Virginia: 2012}

For more information on the USGS — the Federal source for science about the Earth, its natural and living resources, natural hazards, and the environment, visit http://www.usgs.gov or call 1-888-ASK-USGS.

For an overview of USGS information products, including maps, imagery, and publications, visit http://www.usgs.gov/pubprod

To order this and other USGS information products, visit http://store.usgs.gov

Any use of trade, product, or firm names is for descriptive purposes only and does not imply endorsement by the U.S. Government.

Although this report is in the public domain, permission must be secured from the individual copyright owners to reproduce any copyrighted materials contained within this report.

Suggested citation:

Foster, A.L., Katz, B.G., and Meyer, M.T., 2012, Occurrence and potential transport of selected pharmaceuticals and other organic wastewater compounds from wastewater-treatment plant influent and effluent to groundwater and canal systems in Miami-Dade County, Florida: U.S. Geological Survey Scientific Investigations Report 2012-5083,

$64 \mathrm{p}$, plus appendixes. 


\section{Contents}

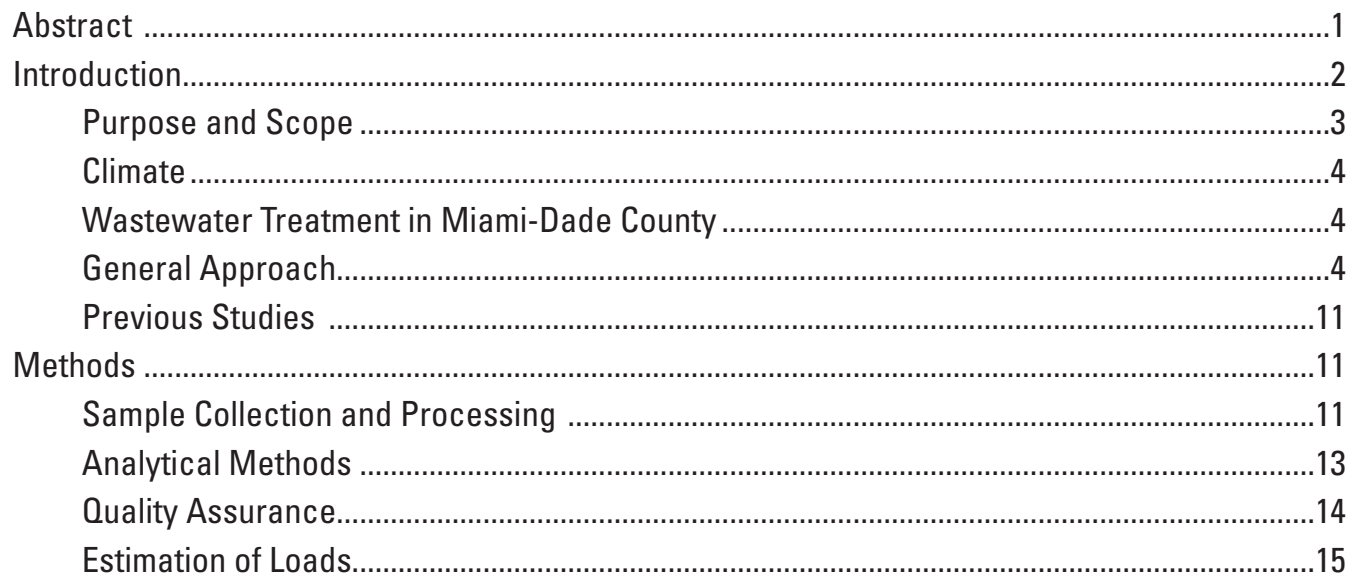

Pharmaceuticals and Other Organic Wastewater Compounds Detected in Wastewater

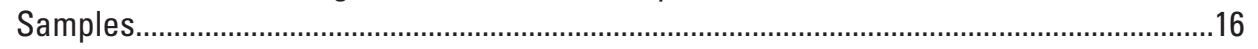

Pharmaceuticals and Other Organic Wastewater Compounds Detected in 24-Hour Flow-Weighted Influent Composite Samples .............................................................16

Pharmaceuticals and Other Organic Wastewater Compounds Detected in 24-Hour Flow-Weighted Effluent Composite Samples .............................................................28

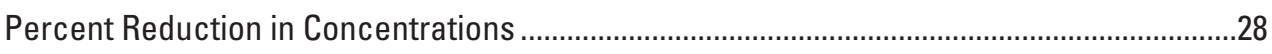

Semivolatile Organic Compounds ...............................................................................

Pesticides and Pesticide Degradates .........................................................................30

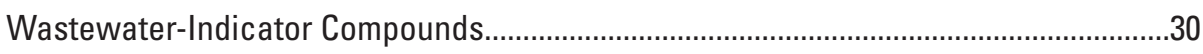

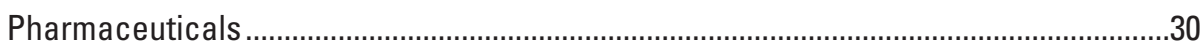

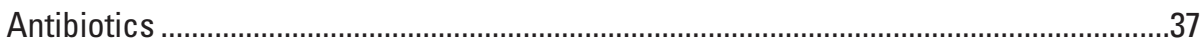

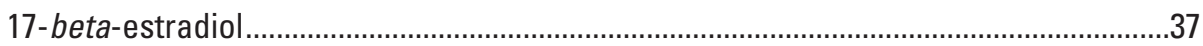

Pharmaceuticals and Other Organic Wastewater Compounds Detected in Groundwater, Canal Water, and Canal Bed Sediments..........................................................................37

Pharmaceuticals and Other Organic Wastewater Compounds in Groundwater near Effluent Soakage Trenches......................................................................................37

Pharmaceuticals and Other Organic Wastewater Compounds in Canal Water and

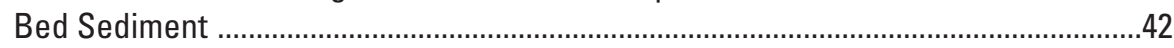

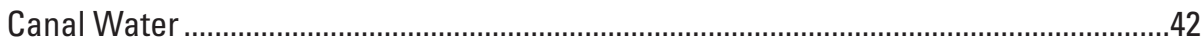

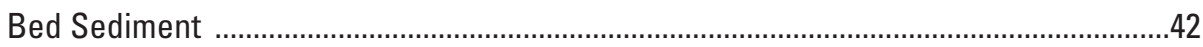

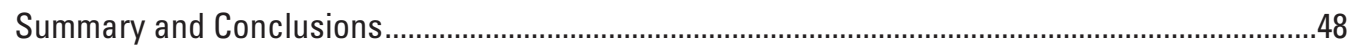

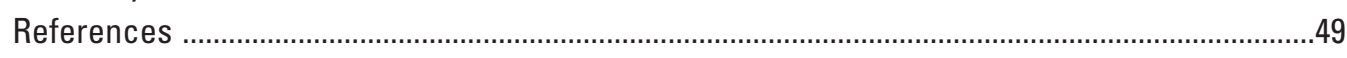

Appendix 1. Quality-assurance data for blank, replicate, and matrix spike samples ....................53

Appendix 2. Percent recovery values for surrogate compounds added to groundwater, surface-water, effluent, and influent samples at the U.S. Geological Survey National Water Quality Laboratory...

Appendix 3. Concentrations of pharmaceuticals and organic wastewater compounds in 24-hour flow-weighted influent and effluent composite samples (link)...

Appendix 4. Total concentrations and estimated loads of pharmaceuticals and organic wastewater compounds detected in 24-hour flow-weighted influent and effluent composite samples (link) 


\section{Figures}

1. Map of Miami-Dade County showing location of the North District Wastewater Treatment Plant, Central District Wastewater Treatment Plant, South District Wastewater Treatment Plant, Homestead Wastewater Treatment Plant, physiographic provinces, and the Biscayne Bay coastal wetlands in southeastern Florida.....

2. Map showing location of Homestead Wastewater Treatment Plant, monitoring wells and canal sampling site locations, and soakage trenches in the Miami-Dade County, Florida, study area.

3. Graphs showing total concentration and daily loads of pharmaceuticals and other organic wastewater compounds in the influent water samples from wastewater-treatment plants in Miami-Dade County, Florida.

4. Graphs showing total concentration and daily loads of pharmaceuticals and other organic wastewater compounds in the effluent water samples from wastewater-treatment plants in Miami-Dade County, Florida....

5. Graph showing concentrations of pharmaceuticals and other organic wastewater compounds detected in the Homestead Wastewater Treatment Plant (HSWWTP) effluent and groundwater samples collected from three monitoring wells at the HSWWTP in Florida.

6. Graph showing comparison of pharmaceuticals and other organic wastewater compounds in groundwater samples collected in both the wet season and dry season from three monitoring wells at the Homestead Wastewater Treatment Plant in Florida.

7. Graph showing comparison of wet- and dry-season concentrations of pharmaceuticals and other organic wastewater compounds detected in canalwater samples collected from canal sampling sites $\mathrm{MC}-1$ and $\mathrm{MC}-2$ in Florida.

8. Graph showing concentrations of wastewater-indicator compounds in bed sediment samples collected from canal sampling sites SC-1, MC-1, and MC-2 ..........45

9. Graph showing comparison of wet- and dry-season concentrations of organic wastewater compounds in bed sediment samples collected from canal sampling sites MC-1 and MC-2 in Florida.

\section{Tables}

1. Summary of wastewater-treatment plants and sampling information for this study........5

2. Pharmaceuticals and other organic wastewater compounds analyzed in water

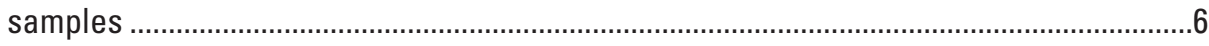

3. Wastewater-indicator compounds analyzed in bed sediment samples .........................12

4. Summary of concentrations of pharmaceuticals and other organic wastewater compounds detected in 24-hour flow-weighted influent composite samples

5. Summary of concentrations of pharmaceuticals and other organic wastewater compounds detected in 24-hour flow-weighted effluent composite samples.

6. Percent reduction in concentrations between influent and effluent samples collected from wastewater-treatment plants

7. Pharmaceuticals and other organic wastewater compounds detected in the Homestead Wastewater Treatment Plant (HSWWTP) effluent samples and groundwater samples collected from three monitoring wells at the HSWWTP.

8. Pharmaceuticals and other organic wastewater compounds detected in canal-water samples

9. Wastewater-indicator compounds detected in canal bed sediment samples 46 


\section{Conversion Factors and Abbreviations}

\begin{tabular}{|c|c|c|}
\hline Multiply & By & To obtain \\
\hline \multicolumn{3}{|c|}{ Length } \\
\hline inch (in.) & 2.54 & centimeter $(\mathrm{cm})$ \\
\hline inch (in.) & 25.4 & millimeter $(\mathrm{mm})$ \\
\hline foot $(\mathrm{ft})$ & 0.3048 & meter $(\mathrm{m})$ \\
\hline mile (mi) & 1.609 & kilometer $(\mathrm{km})$ \\
\hline \multicolumn{3}{|c|}{ Volume } \\
\hline gallon (gal) & 3.785 & liter $(\mathrm{L})$ \\
\hline gallon (gal) & 0.003785 & cubic meter $\left(\mathrm{m}^{3}\right)$ \\
\hline million gallons (Mgal) & 3,785 & cubic meter $\left(\mathrm{m}^{3}\right)$ \\
\hline \multicolumn{3}{|c|}{ Flow rate } \\
\hline acre-foot per day (acre-ft/d) & 0.01427 & cubic meter per second $\left(\mathrm{m}^{3} / \mathrm{s}\right)$ \\
\hline acre-foot per year (acre-ft/yr) & 1,233 & cubic meter per year $\left(\mathrm{m}^{3} / \mathrm{yr}\right)$ \\
\hline acre-foot per year (acre-ft/yr) & 0.001233 & cubic hectometer per year $\left(\mathrm{hm}^{3} / \mathrm{yr}\right)$ \\
\hline foot per second $(\mathrm{ft} / \mathrm{s})$ & 0.3048 & meter per second $(\mathrm{m} / \mathrm{s})$ \\
\hline cubic foot per second $\left(\mathrm{ft}^{3} / \mathrm{s}\right)$ & 0.02832 & cubic meter per second $\left(\mathrm{m}^{3} / \mathrm{s}\right)$ \\
\hline $\begin{array}{l}\text { cubic foot per second per square mile } \\
{\left[\left(\mathrm{ft}^{3} / \mathrm{s}\right) / \mathrm{mi}^{2}\right]}\end{array}$ & 0.01093 & $\begin{array}{l}\text { cubic meter per second per square kilo- } \\
\text { meter }\left[\left(\mathrm{m}^{3} / \mathrm{s}\right) / \mathrm{km}^{2}\right]\end{array}$ \\
\hline cubic foot per day $\left(\mathrm{ft}^{3} / \mathrm{d}\right)$ & 0.02832 & cubic meter per day $\left(\mathrm{m}^{3} / \mathrm{d}\right)$ \\
\hline gallon per minute (gal/min) & 0.06309 & liter per second $(\mathrm{L} / \mathrm{s})$ \\
\hline gallon per day (gal/d) & 0.003785 & cubic meter per day $\left(\mathrm{m}^{3} / \mathrm{d}\right)$ \\
\hline million gallons per day $(\mathrm{Mgal} / \mathrm{d})$ & 0.04381 & cubic meter per second $\left(\mathrm{m}^{3} / \mathrm{s}\right)$ \\
\hline \multicolumn{3}{|c|}{ Mass } \\
\hline ounce, avoirdupois (oz) & 28.35 & $\operatorname{gram}(\mathrm{g})$ \\
\hline pound, avoirdupois (lb) & 0.4536 & kilogram $(\mathrm{kg})$ \\
\hline \multicolumn{3}{|c|}{ Hydraulic conductivity } \\
\hline foot per day (ft/d) & 0.3048 & meter per day $(\mathrm{m} / \mathrm{d})$ \\
\hline \multicolumn{3}{|c|}{ Transmissivity* $^{*}$} \\
\hline foot squared per day $\left(\mathrm{ft}^{2} / \mathrm{d}\right)$ & 0.09290 & meter squared per day $\left(\mathrm{m}^{2} / \mathrm{d}\right)$ \\
\hline
\end{tabular}

Temperature in degrees Celsius $\left({ }^{\circ} \mathrm{C}\right)$ may be converted to degrees Fahrenheit $\left({ }^{\circ} \mathrm{F}\right)$ as follows:

${ }^{\circ} \mathrm{F}=\left(1.8 x^{\circ} \mathrm{C}\right)+32$

Concentrations of chemical constituents in water are given in micrograms per liter ( $\mu \mathrm{g} / \mathrm{L})$.

Concentrations of chemical constituents in sediments are given in micrograms per kilogram $(\mu \mathrm{g} / \mathrm{kg})$.

Loads were calculated by multiplying the average flow during each 24-hour sampling period by total concentrations of constituents in the effluent and by a conversion factor $\left(8.34 \times 10^{-9}\right)$ to convert million gallons per day and micrograms per liter to pounds per day. 


\section{Chemical Abbreviations}

$\begin{array}{ll}\text { 3,4-DCA } & \text { 3,4-dichloroaniline } \\ \text { AHTN } & \text { Tonalide } \\ \text { BHA } & \text { 3-tert-butyl-4-hydroxyanisole } \\ \text { CIAT } & \text { 2-Chloro-4-isopropylamino-6-amino-s-triazine } \\ \text { DCB } & \text { 1,4-Dichlorobenzene } \\ \text { DEET } & \text { N-N-diethyl-meta-toluamide } \\ \text { DEHP } & \text { Diethylhexyl phthalate } \\ \text { DO } & \text { dissolved oxygen } \\ \text { E2 } & \text { 17-beta-Estradiol } \\ \text { HHCB } & \text { Galaxolide } \\ \text { NDMA } & \text { N-Nitrosodimethylamine } \\ \text { NP } & \text { 4-Nonylphenol (total) } \\ \text { NP }{ }_{1} \text { EO } & \text { 4-Nonylphenol monoethoxylate } \\ \text { NP }{ }_{2} \text { EO } & \text { 4-Nonylphenol diethoxylate } \\ \text { OP } & \text { 4-tert-0ctylphenol } \\ \text { OP }{ }_{1} \text { EO } & \text { 4-Octylphenol monoethoxylate } \\ \text { OP }{ }_{2} \text { EO } & \text { 4-Octylphenol diethoxylate } \\ \text { SVOCs } & \text { Semivolatile organic compounds } \\ \text { TBEP } & \text { Tri(2-butoxyethyl) phosphate } \\ \text { TCEP } & \text { Tri(2-chloroethyl) phosphate } \\ \text { TDCP } & \text { Trildichloroisopropyl) phosphate } \\ \text { TBP } & \text { Tributylphosphate } \\ & \end{array}$




\section{Abbreviations}

$\begin{array}{ll}\text { C } & \text { Unable to compute percent reduction value } \\ \text { CD1 } & \text { Central District Wastewater Treatment Plant 1 } \\ \text { CD2 } & \text { Central District Wastewater Treatment Plant 2 } \\ \text { CDWWTP } & \text { Central District Wastewater Treatment Plant } \\ \text { CLLE } & \text { Continuous liquid-liquid extraction } \\ \text { DERM } & \text { Miami-Dade Department of Environmental Resources Management } \\ \text { E } & \text { Estimated value } \\ \text { ELISA } & \text { Enzyme-linked immunosorbent assay } \\ \text { ESI } & \text { Electrospray ionization } \\ \text { GC } & \text { Gas chromatography } \\ \text { HPLC } & \text { High-performance liquid chromatography } \\ \text { hr } & \text { hour } \\ \text { HSWWTP } & \text { Homestead Wastewater Treatment Plant } \\ \text { Ib/d } & \text { Pounds per day } \\ \text { LC } & \text { Liquid chromatography } \\ \text { MCL } & \text { Maximum contaminant level } \\ \text { MDL } & \text { Method detection level } \\ \text { Mgal/d } & \text { Million gallons per day } \\ \text { MRL } & \text { Method reporting level } \\ \text { MC } & \text { Mowry Canal } \\ \text { MS } & \text { Mass spectrometry } \\ \text { MW } & \text { monitoring well } \\ \mu \text { g/L } & \text { Microgram per liter } \\ \text { ND } & \text { North District Wastewater Treatment Plant - one plant only } \\ \text { NDWWTP } & \text { North District Wastewater Treatment Plant } \\ \text { NWOL } & \text { U.S. Geological Survey National Water Quality Laboratory } \\ \text { OGRL } & \text { U.S. Geological Survey Organic Geochemistry Research Laboratory } \\ \text { OLSPE } & \text { On-line solid-phase extraction } \\ \text { PCPs } & \text { Personal care products } \\ \text { OA } & \text { Quality assurance } \\ \text { RPD } & \text { Relative percent difference } \\ \text { SBR } & \text { Sequential batch reactor } \\ \text { SC } & \text { Snapper Creek } \\ \text { SD1 } & \text { South District Wastewater Treatment Plant 1 } \\ \text { SD2 } & \text { South District Wastewater Treatment Plant 2 } \\ \text { SDWWTP } & \text { South District Wastewater Treatment Plant } \\ \text { SPE } & \text { Solid-phase extraction } \\ \text { USEPA } & \text { U.S. Environmental Protection Agency } \\ \text { USGS } & \text { U.S. Geological Survey } \\ \text { WASD } & \text { Miami-Dade Water and Sewer Department } \\ \text { WWater-treatment plant } \\ \text { DS }\end{array}$




\section{Acknowledgments}

The authors gratefully thank the many wastewater-treatment plant personnel for their assistance with sample collection. Special thanks are extended to Clive Powell, Steve Kronheim, Andy Toledo, Yvonne Walton, Manny Moncholi (Miami-Dade Water and Sewer Department), and Steve Anderson (City of Homestead) for their technical assistance at the facilities. Virginia Walsh, Sonia Villamil (Miami-Dade Water and Sewer Department) and Julie Baker (Miami-Dade Department of Environmental Resources Management) provided invaluable logistical assistance.

The authors benefited greatly from discussions with Pat Phillips, Steve Smith, and Dan Edwards (U.S. Geological Survey) on sampling and analysis of pharmaceuticals and other organic wastewater compounds. Carrie Boudreau, Amarys Acosta, and Michele Markovits (U.S. Geological Survey) assisted in sample collection and processing. Amy Gill and Steven Sando (U.S. Geological Survey) provided helpful reviews of this report. 


\title{
Occurrence and Potential Transport of Selected Pharmaceuticals and Other Organic Wastewater Compounds from Wastewater-Treatment Plant Influent and Effluent to Groundwater and Canal Systems in Miami-Dade County, Florida
}

\author{
By Adam L. Foster, Brian G. Katz, and Michael T. Meyer
}

\begin{abstract}
An increased demand for fresh groundwater resources in South Florida has prompted Miami-Dade County to expand its water reclamation program and actively pursue reuse plans for aquifer recharge, irrigation, and wetland rehydration. The U.S. Geological Survey, in cooperation with the Miami-Dade Water and Sewer Department (WASD) and the Miami-Dade Department of Environmental Resources Management (DERM), initiated a study in 2008 to assess the presence of selected pharmaceuticals and other organic wastewater compounds in the influent and effluent at three regional wastewater-treatment plants (WWTPs) operated by the WASD and at one WWTP operated by the City of Homestead, Florida (HSWWTP).

To assess the range in concentrations of pharmaceuticals and other organic wastewater compounds in influent and effluent waters, 24-hour (hr) flow-weighted composite water samples were collected from the influent and effluent at each plant and analyzed for a broad range of pharmaceuticals and other organic wastewater compounds. These analyses included semivolatile organic compounds, pesticides and pesticide degradates, wastewater-indicator compounds, pharmaceuticals, antibiotics, and one hormone. Water samples were collected once in the wet season (high-flow conditions) and once in the dry season (low-flow conditions) to capture any seasonal variations in concentrations. Compounds detected in 24-hr flow-weighted influent composite samples included: 20 semivolatile organic compounds, 12 pesticides and pesticide degradates, 52 wastewater-indicator compounds, 5 pharmaceuticals, 14 antibiotics, and the hormone 17-beta-estradiol. Compounds detected in 24-hr flow-weighted effluent composite samples included: 19 semivolatile organic compounds, 13 pesticides, 49 wastewater-indicator compounds, 7 pharmaceuticals, 11 antibiotics, and 17-beta-estradiol. Percent reductions during treatment were calculated when possible. Among the various groups of compounds, semivolatile organic compounds and
\end{abstract}

wastewater-indicator compounds generally had higher removal efficiencies than pharmaceuticals, antibiotics, and pesticides. Qualitatively, the total concentrations of pharmaceuticals and other organic wastewater compounds in the effluent at each plant were slightly higher in the dry season compared to the wet season; however, loads to the environment were generally larger in the wet season due to the higher flows through the WWTPs.

For decades, the HSWWTP has been discharging treated effluent directly to the water table using onsite soakage trenches. Water samples were collected from three monitoring wells at the HSWWTP to determine the occurrence of pharmaceuticals and other organic wastewater compounds in groundwater near the soakage trenches. Concentrations in the groundwater were generally below 0.5 microgram per liter $(\mu \mathrm{g} / \mathrm{L})$ with the exception of the fragrance galaxolide (estimated at $0.62-1.3 \mu \mathrm{g} / \mathrm{L}$ ), the antibiotic sulfamethoxazole $(0.14-0.57 \mu \mathrm{g} / \mathrm{L})$, and the flame retardant tri(2-butoxyethyl) phosphate (estimated at $0.51 \mu \mathrm{g} / \mathrm{L}$ ). Most pharmaceuticals and other organic wastewater compounds were attenuated in groundwater at this site; however, galaxolide, sulfamethoxazole, 3,4-dichloroaniline, 1,2-dichlorobenzene, and carbamazepine were detected in all groundwater samples, thus indicating that these compounds may be used as tracers of effluent at this site. Water samples were collected from monitoring wells once in the wet season and once in the dry season to determine any seasonal variations in concentrations. Results from seasonal sampling indicate that concentrations of pharmaceuticals and other organic wastewater compounds in groundwater are higher in the wet season, which is most likely related to the larger effluent loads to the groundwater during wet months.

Water and bed sediment samples were collected from two canal sites near the HSWWTP. These samples were analyzed for pharmaceuticals and other organic compounds to determine if compounds present in the effluent are being 
transported through the groundwater system and into the canal system. Water and bed sediment samples were also collected from one background canal site in Miami-Dade County, with no known sources of wastewater in the area, to compare with results from the canal near the HSWWTP. Results from these samples indicated that 51 compounds were detected in one or more canal samples with concentrations generally below $1.0 \mu \mathrm{g} / \mathrm{L}$. A high estimated concentration of the plasticizer, diethylhexyl phthalate (DEHP, estimated at $11 \mu \mathrm{g} / \mathrm{L}$ ), was detected in a canal water sample close to the HSWWTP; however, the source of this compound to the canal is most likely from surface runoff or the application of pesticides and not the HSWWTP. Results from seasonal sampling from the two canal sites indicated that concentrations of pharmaceuticals and other organic wastewater compounds were generally higher in the dry season. Water samples collected from the background canal site contained low levels (less than $0.76 \mu \mathrm{g} / \mathrm{L}$ ) of 11 organic compounds in water samples, including 5 wastewaterindicator compounds and the non-prescription pharmaceutical acetaminophen; bed sediments contained detectable levels of 16 wastewater-indicator compounds. The presence of these compounds in water and bed sediment samples indicates that there is a probable nonpoint source of wastewater in the area.

\section{Introduction}

As demand for fresh groundwater resources increases, artificial recharge using highly treated wastewater, or reclaimed water, is becoming a widely utilized management technique to recharge aquifers in Florida and other parts of the United States (National Research Council, 1998; U.S. Environmental Protection Agency, 1994; Florida Department of Environmental Protection, 2010). An estimated 38 billion gallons of reclaimed water are used in Florida to recharge aquifers annually (WaterReuse Foundation, 2008). However, the use of reclaimed water for aquifer recharge in MiamiDade County, a highly populated area on the southeastern coast of Florida, has been limited. Currently (2011), the City of Homestead operates the only wastewater-treatment plant (HSWWTP) in Miami-Dade County that uses reclaimed water for aquifer recharge (fig. 1). In 2008, an average of 5.17 million gallons per day (Mgal/d; or approximately 1.9 billion gallons total for the year) of tertiary-treated wastewater was used to recharge the Biscayne aquifer (Florida Department of Environmental Protection, 2010).

The Miami-Dade County Water and Sewer Department (WASD) is responsible for the collection, treatment, and disposal of the majority of the wastewater in the county and operates three regional wastewater-treatment plants (WWTPs) (North, Central, and South Districts, hereafter referred to as NDWWTP, CDWWTP, and SDWWTP, respectively) (fig. 1). These facilities dispose of approximately $300 \mathrm{Mgal} / \mathrm{d}$ (on average) of secondary-treated effluent through direct discharge of the treated effluent to ocean outfalls or through deep-well injection into the saline, confined Boulder Zone of the Lower Floridan aquifer. In 2008, the Florida legislature passed a bill setting a deadline for the elimination of existing wastewater ocean outfalls by 2025 , with an added requirement that a majority of the wastewater previously discharged through this method be beneficially reused. In response to this bill, WASD is seeking to increase the amount of wastewater reused from its regional WWTPs, and is actively pursuing reuse plans to use reclaimed water for various purposes. For example, WASD is investigating the use of highly treated wastewater to restore historic freshwater flows to the Biscayne Bay coastal wetlands as part of the Comprehensive Everglades Restoration Plan. Also, a reclaimed water plant is under construction at the SDWWTP, which will recharge the Biscayne aquifer near the Zoo Miami with $21 \mathrm{Mgal} / \mathrm{d}$ of highly treated wastewater.

The Biscayne aquifer, a sole source aquifer comprising the uppermost part of the surficial aquifer system of southern Florida, is a highly permeable karst aquifer with estimates of transmissivity exceeding 300,000 square feet per day $\left(\mathrm{ft}^{2} / \mathrm{d}\right.$; Fish and Stewart, 1991). Recent research has indicated the presence of stratiform, high-porosity zones of preferred flow within this carbonate system, which can serve as channels for potential rapid movement of contaminants (Cunningham and others, 2004; Renken and others, 2008). Embedded in the upper part of the surficial aquifer system is an interconnected system of man-made surface-water canals that serve a dual purpose. These canals (1) drain the Biscayne aquifer in the wet season to prevent flooding with discharge of excess water to Biscayne Bay and coastal wetlands (fig. 1), and (2) maintain heads in the aquifer in the dry season to prevent saltwater intrusion. Due to the high transmissivity of the Biscayne aquifer, the surface-water canals are directly connected to the groundwater system with aquifer responses being substantially influenced by canal operations.

Municipal wastewater contains many organic chemicals including prescription and non-prescription pharmaceuticals, human and veterinary antibiotics, pesticides, reproductive hormones, and other wastewater organic compounds. Although many are currently unregulated, some of these chemicals present known and potential health hazards to humans and other biota. In particular, pharmaceuticals, which are specifically designed to affect biological processes, have been identified as "Chemicals of Emerging Environmental Concern" by the U.S. Geological Survey (USGS) Toxic Substances Hydrology Program (U.S. Geological Survey, 2010). A critical concern when using reclaimed water, especially when reclaimed water is being used to recharge a public drinking-water supply, is to determine how effective treatment processes are in removing organic compounds from the water. Because the Biscayne aquifer is highly permeable, WASD and the Miami-Dade County Department of Environmental Resources Management (DERM) are concerned about the potential transport of these compounds from recharge areas to municipal supply well fields. Furthermore, because the Biscayne aquifer is interconnected with the canal system, there is potential for these compounds to be transported to the canal system and eventually 


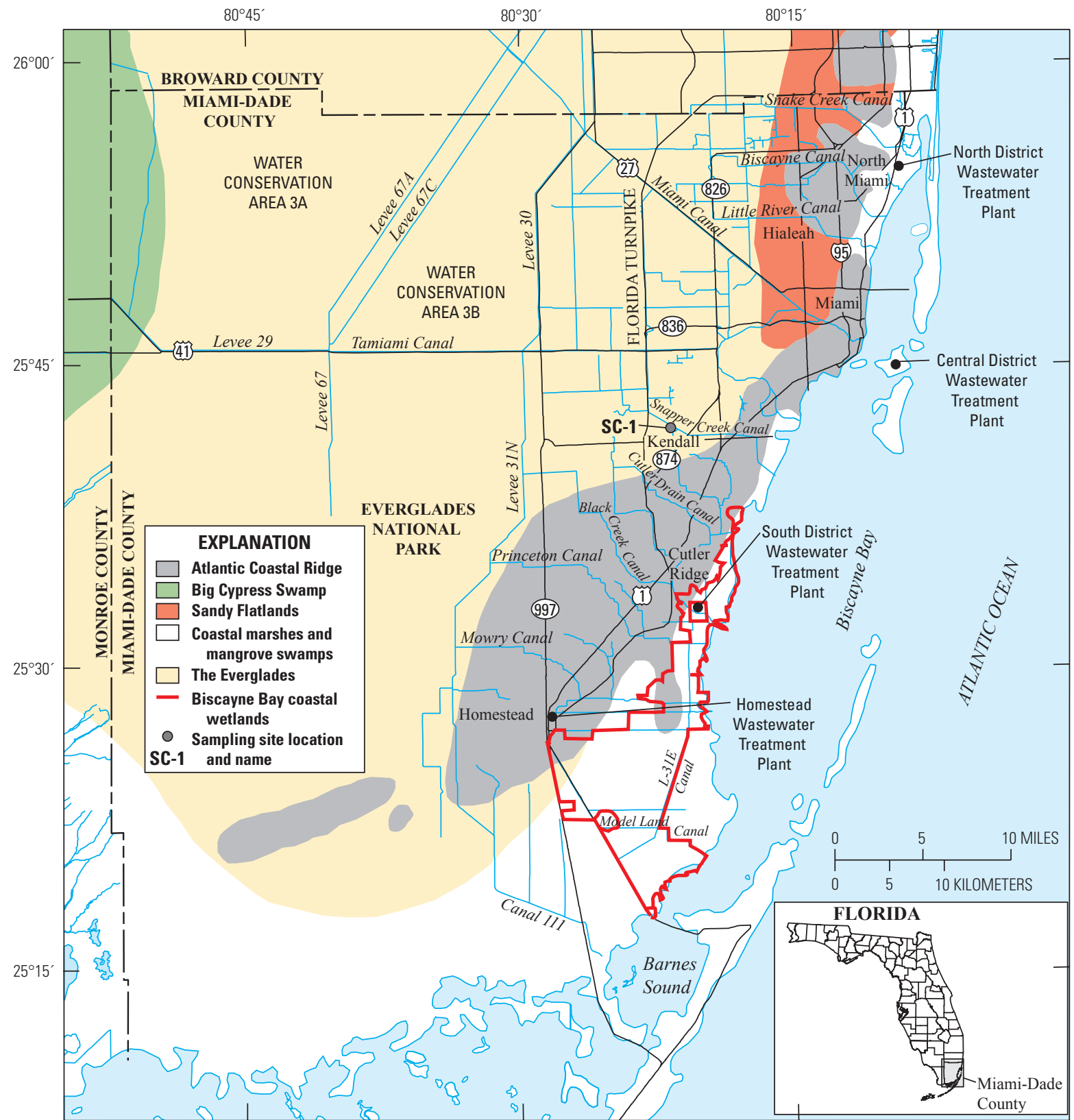

Base from U.S. Geological Survey digital data

Universal Transverse Mercator projection, Zone 17, Datum NAD 27

Figure 1. Miami-Dade County showing location of the North District Wastewater Treatment Plant, Central District Wastewater Treatment Plant, South District Wastewater Treatment Plant, Homestead Wastewater Treatment Plant, physiographic provinces, and the Biscayne Bay coastal wetlands in southeastern Florida.

to sensitive coastal estuarine and wetland systems (fig. 1). The USGS in cooperation with WASD and DERM initiated a study in 2008 to evaluate: (1) the presence of pharmaceuticals and other organic wastewater compounds in the influent and effluent at WASD's three regional WWTPs and at HSWWTP, (2) the percent reduction of compounds during treatment at each WWTP using current (2008) treatment processes, and (3) the occurrence of pharmaceuticals and other organic wastewater compounds in groundwater, canal water, and canal bed sediments near the HSWWTP.

\section{Purpose and Scope}

The purposes of this report are to: (1) assess and document the occurrence and concentrations of selected pharmaceuticals and other organic wastewater compounds in WWTP influent and effluent, groundwater, canal water, and canal sediment samples at selected sites in Miami-Dade County; (2) assess the persistence of these compounds during wastewater treatment by comparing influent and effluent concentrations, loads, and seasonal variations, and by calculating 
percent reduction of individual compounds during treatment at each plant; and (3) assess the potential transport of these compounds from recharge areas through the groundwater system and into the canal system by comparing effluent concentrations at the HSWWTP with concentrations in nearby groundwater, nearby canal water and bed sediments, and more distant canal water and bed sediments.

Background information about the WWTPs is provided, including the treatment processes used. Sampling and processing methods and the laboratory analytical methods are described, and analytical results are presented from dry-season and wet-season sampling events. Results of field and laboratory quality-assurance procedures are presented.

\section{Climate}

The climate in southeastern Florida is tropical with average annual air temperature of $24.7^{\circ} \mathrm{C}$ and average annual precipitation of 58.53 inches (in.) for the period 1971-2000, measured at the National Oceanic and Atmospheric Administration (NOAA) weather station at the Miami International Airport (National Oceanic and Atmospheric Administration, 2004). An average of 43.05 in. (about 74 percent of the annual rainfall) of rainfall occurs during the wet season (May through October) and is associated with thunderstorms and tropical cyclones. August is typically the wettest month, with 8.63 in. (about 15 percent of the annual rainfall). Rainfall during the dry season (November through April) is relatively light, averaging only about 2.5 in. per month.

\section{Wastewater Treatment in Miami-Dade County}

The WWTPs in this study treat a mixture of residential, municipal, and industrial wastewater as well as stormwater runoff during rainfall events. Stormwater runoff can contain runoff from streets, parking lots, rooftops, parks, and lawns. The average daily flow during the wet season to each plant can be more than two times the annual average daily flow due to stormwater runoff.

The three Miami-Dade Water and Sewer Department facilities (NDWWTP, CDWWTP, and SDWWTP ) vary in flow, population served, and ratio of residential to industrial wastewater treated. The NDWWTP consists of only one plant (ND) whereas the CDWWTP and SDWWTP consist of two separate plants that run in parallel. The two plants at the CDWWTP (CD1 and CD2) and SDWWTP (SD1 and SD2) were considered separate plants for this study because they receive wastewater from different areas and vary in flow (table 1). Combined, the three facilities are permitted to treat $368 \mathrm{Mgal} / \mathrm{d}$ of wastewater. The three facilities treat wastewater using an advanced treatment process known as "pure oxygen activated sludge." Briefly, raw wastewater (influent) enters the aerated grit chambers where particulate inorganic material settles and is collected for eventual transport to a disposal facility. Wastewater subsequently enters the aeration basins where 95-percent pure oxygen, generated by cryogenic oxygen generators, is diffused into the waste stream to facilitate bacterial multiplication and biodegradation of organic solids. Wastewater then flows to the secondary clarifiers where biosolids are allowed to settle and then removed. The treated wastewater (effluent) from the clarifiers then goes to the pump houses where it is either discharged to ocean outfalls or injected into the saline, confined Boulder Zone of the Lower Floridan aquifer (table 1). Effluent discharged to ocean outfalls is disinfected with chlorine prior to disposal.

The Homestead WWTP (HSWWTP) is permitted to treat $6 \mathrm{Mgal} / \mathrm{d}$ of wastewater from approximately 58,000 people within the City of Homestead. Treatment of wastewater begins in one of four identical sequential batch reactors (SBRs). Briefly, influent fills one of the reactors (tanks) and the wastewater is aerated. After aeration, the solids in the water are allowed to settle and the water is then decanted. While one of the tanks is in settle/decant mode, another is filling and aerating. Effluent from the tanks is then filtered using a sand/mixed media followed by disinfection of treated water by ultraviolet reactors. Treated effluent from the plant is then discharged directly to the Biscayne aquifer using rapid-rate adsorption soakage trenches (fig. 2). The average daily flow at the HSWWTP in 2009 was $5.1 \mathrm{Mgal} / \mathrm{d}$ (S. Anderson, City of Homestead, written commun., 2010).

\section{General Approach}

To assess the reduction of pharmaceuticals and other organic wastewater compounds during treatment, 24-hour (hr) flow-weighted composite water samples were collected from the influent and effluent at each plant (ND, CD1, CD2, SD1, SD2, and HS). These samples were collected on two occasions, once in the wet season and once in the dry season, and analyzed for selected pharmaceuticals and other organic wastewater compounds (table 2). Concentrations and total loads were compared for the influent and the effluent samples at a site and a percent reduction was calculated.

To investigate the possible transport of pharmaceuticals and other organic wastewater compounds in groundwater from the discharge of treated wastewater in the soakage trenches at the HSWWTP, three monitoring wells (MW) at varying distances from the soakage trenches (MW-1, MW-2, and MW-3; fig. 2) were sampled and analyzed for selected pharmaceuticals and other organic wastewater compounds (table 2). The monitoring wells were sampled once in the wet season and once in the dry season to determine if concentrations varied seasonally. Effluent and groundwater concentrations were compared as were wet-season and dry-season concentrations.

To investigate the possible transport of pharmaceuticals and other organic wastewater compounds through the groundwater system and into the canal system, canal water samples were collected from two sites near the HSWWTP in the Mowry Canal (MC-1, MC-2; fig. 2) and analyzed for selected pharmaceuticals and other organic wastewater compounds (table 2). 
Table 1. Summary of wastewater-treatment plants and sampling information for this study.

[Mgal/d, million gallons per day; WWTP, wastewater-treatment plant; SBR, Sequential Batch Reactor; POAS, pure oxygen acitvated sludge; F, filtration; UV, ultraviolet; $\mathrm{Cl}$, chlorination; ST, soakage trenches; DWI, deep-well injection; OO, ocean outfall; —, none]

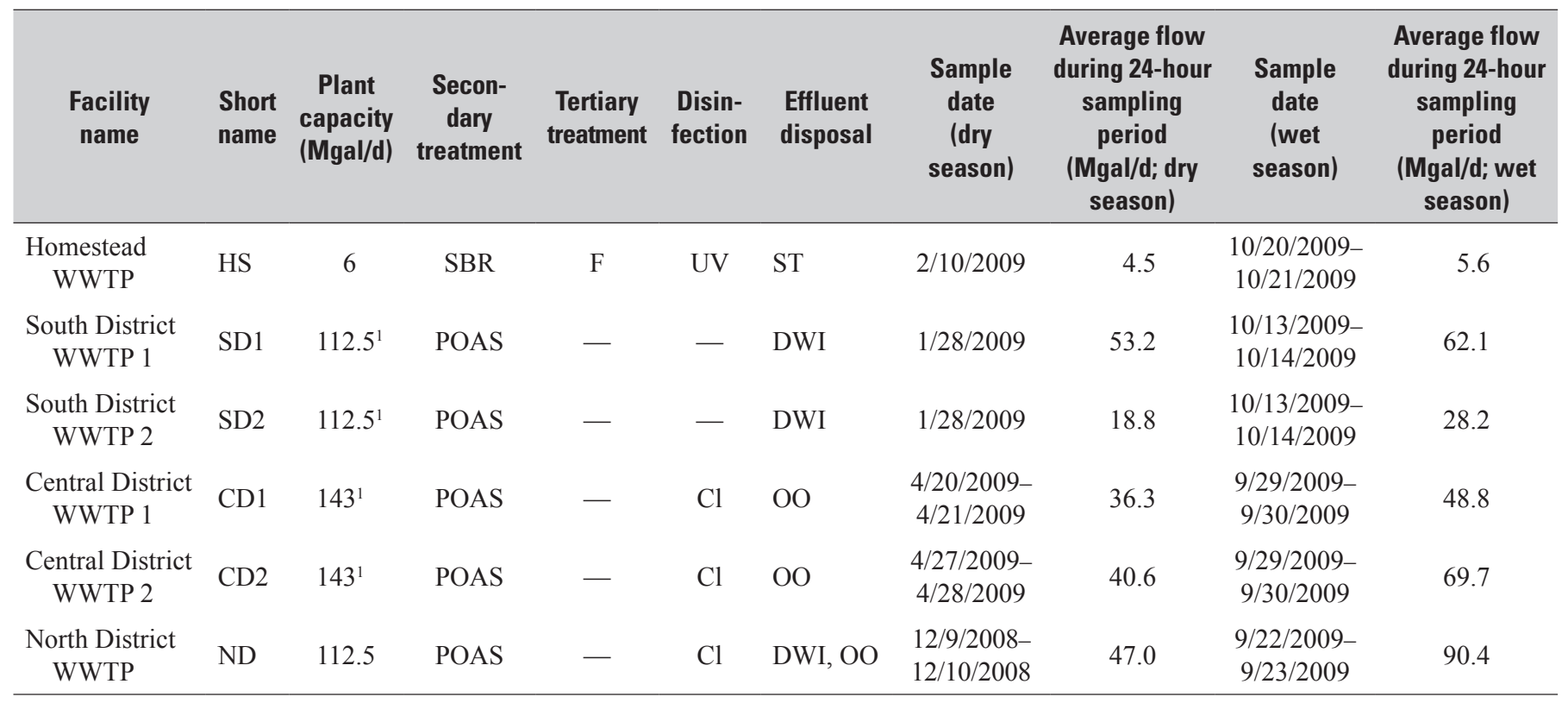

${ }^{1}$ Combined flow

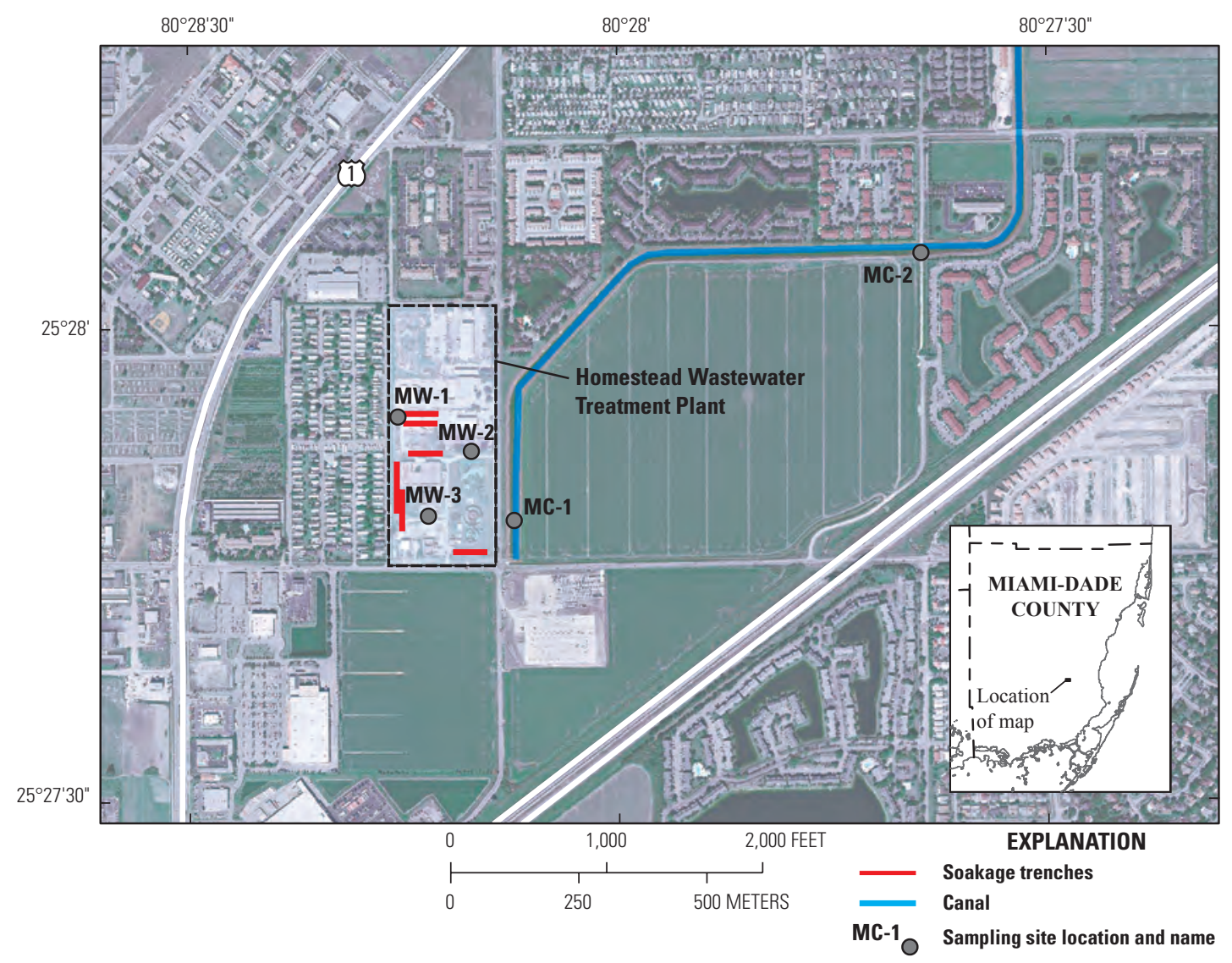

Figure 2. Location of Homestead Wastewater Treatment Plant, monitoring wells and canal sampling site locations, and soakage trenches in the Miami-Dade County, Florida, study area. 
Table 2. Pharmaceuticals and other organic wastewater compounds analyzed in water samples.

[CAS RN, Chemical Abstract Service Registry Number; MRL, method reporting level; $\mu \mathrm{g} / \mathrm{L}$, micrograms per liter; P-Code, U.S. Environmental Protection Agency STORET code; NWQL, U.S. Geological Survey National Water Quality Laboratory; CLLE, Continiuous liquid-liquid extraction; GC/MS, gas chromatogrpahy/mass spectrometry; OGRL, U.S. Geological Survey Organic Geochemistry Research Laboratory; SPE, solid-phase extraction; HPLC/MS, high-performance liquid chromatogrpahy/mass spectrometry; ELISA, enzyme-linked immunosorbent assay; —, not applicable]

\begin{tabular}{|c|c|c|c|}
\hline Compound & CAS RN & $\begin{array}{c}\text { MRL } \\
(\mu \mathrm{g} / \mathrm{L})\end{array}$ & P-Code \\
\hline \multicolumn{4}{|c|}{ Semivolatile organic compounds (NWOL, Unfiltered, CLLE, GC/MS) } \\
\hline 1,2-Dichlorobenzene & $95-50-1$ & 0.2 & 34536 \\
\hline 1,2-Diphenylhydrazine & $122-66-7$ & 0.3 & 82626 \\
\hline 1,3-Dichlorobenzene & $541-73-1$ & 0.22 & 34566 \\
\hline 2,4,6-Trichlorophenol & $88-06-2$ & 0.34 & 34621 \\
\hline 2,4-Dichlorophenol & $120-83-2$ & 0.36 & 34601 \\
\hline 2,4-Dimethylphenol & $105-67-9$ & 0.8 & 34606 \\
\hline 2,4-Dinitrophenol & $51-28-5$ & 1 & 34616 \\
\hline 2,4-Dinitrotoluene & $121-14-2$ & 0.56 & 34611 \\
\hline 4-Bromophenylphenylether & $101-55-3$ & 0.24 & 34636 \\
\hline 4-Chloro-3-methylphenol & $59-50-7$ & 0.54 & 34452 \\
\hline 4-Chlorophenyl phenyl ether & $7005-72-3$ & 0.34 & 34641 \\
\hline 4-Nitrophenol & $100-02-7$ & 0.52 & 34646 \\
\hline Acenaphthene & $83-32-9$ & 0.28 & 34205 \\
\hline Acenaphthylene & $208-96-8$ & 0.3 & 34200 \\
\hline Benz[a]anthracene & $56-55-3$ & 0.26 & 34526 \\
\hline Benzo[b]fluoranthene & $205-99-2$ & 0.3 & 34230 \\
\hline Benzo[ghi]perylene & $191-24-2$ & 0.38 & 34521 \\
\hline Benzo[k]fluoranthene & $207-08-9$ & 0.3 & 34242 \\
\hline Diethylhexyl phthalate (DEHP) & $117-81-7$ & 1.3 & 39100 \\
\hline Dimethyl phthalate & $131-11-3$ & 0.36 & 34341 \\
\hline Di-n-butyl phthalate & $84-74-2$ & 1 & 39110 \\
\hline Di-n-octyl phthalate & $117-84-0$ & 0.6 & 34596 \\
\hline Fluorene & $86-73-7$ & 0.34 & 34381 \\
\hline Hexachlorobenzene & $118-74-1$ & 0.3 & 39700 \\
\hline Hexachlorobutadiene & $87-68-3$ & 0.24 & 39702 \\
\hline Hexachlorocyclopentadiene & $77-47-4$ & 0.5 & 34386 \\
\hline Hexachloroethane & $67-72-1$ & 0.24 & 34396 \\
\hline Indeno[1,2,3-cd]pyrene & $193-39-5$ & 0.38 & 34403 \\
\hline Nitrobenzene & $98-95-3$ & 0.26 & 34447 \\
\hline$N$-Nitrosodimethylamine (NDMA) & $62-75-9$ & 0.24 & 34438 \\
\hline$N$-Nitrosodi-n-propylamine & $621-64-7$ & 0.4 & 34428 \\
\hline $\mathrm{N}$-Nitrosodiphenylamine & $86-30-6$ & 0.28 & 34433 \\
\hline Pentachlorophenol & $87-86-5$ & 0.6 & 39032 \\
\hline
\end{tabular}


Table 2. Pharmaceuticals and other organic wastewater compounds analyzed in water samples.-Continued

[CAS RN, Chemical Abstract Service Registry Number; MRL, method reporting level; $\mu \mathrm{g} / \mathrm{L}$, micrograms per liter; P-Code, U.S. Environmental Protection Agency STORET code; NWQL, U.S. Geological Survey National Water Quality Laboratory; CLLE, Continiuous liquid-liquid extraction; GC/MS, gas chromatogrpahy/mass spectrometry; OGRL, U.S. Geological Survey Organic Geochemistry Research Laboratory; SPE, solid-phase extraction; HPLC/MS, high-performance liquid chromatogrpahy/mass spectrometry; ELISA, enzyme-linked immunosorbent assay; —, not applicable]

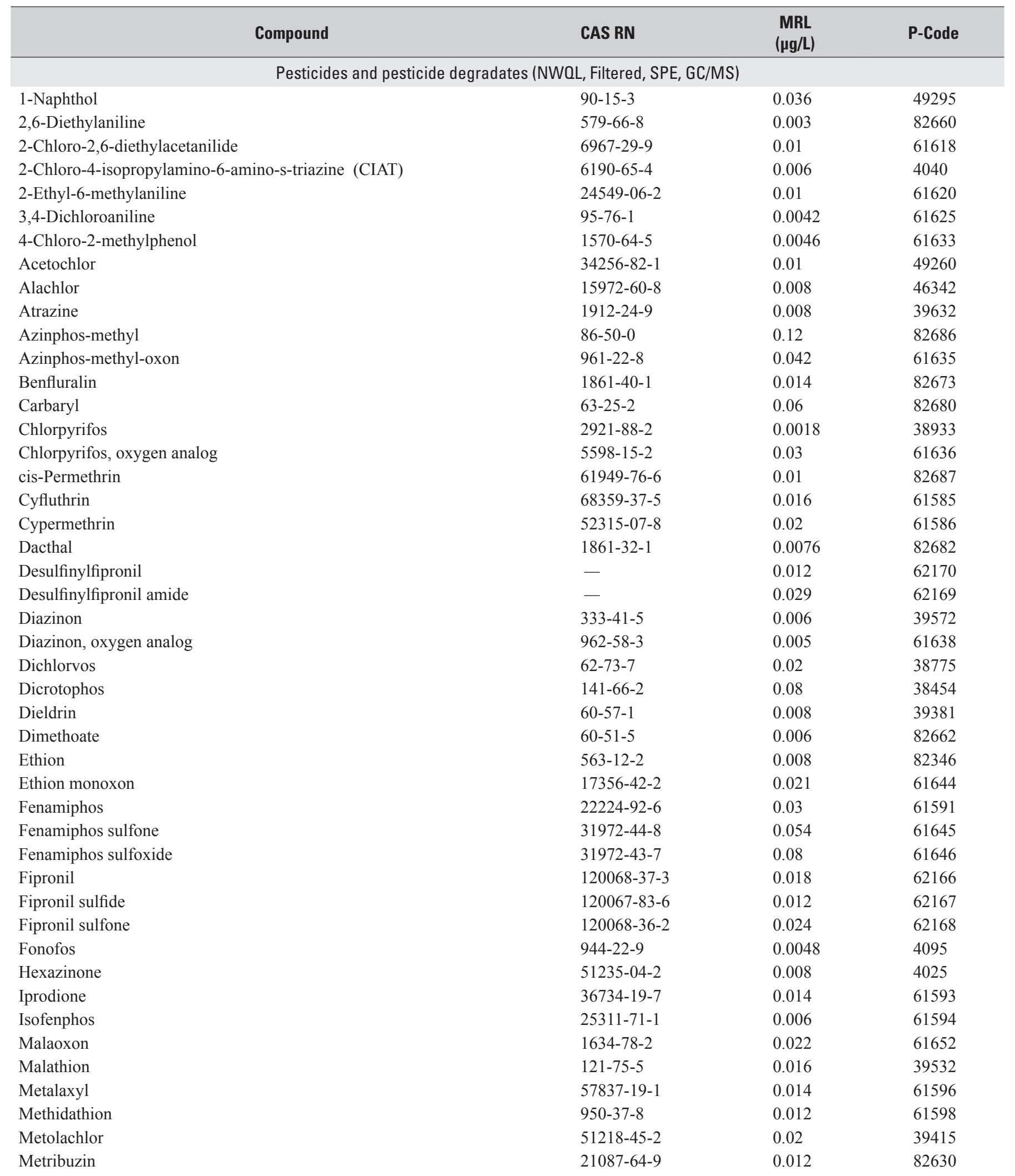


Table 2. Pharmaceuticals and other organic wastewater compounds analyzed in water samples.-Continued

[CAS RN, Chemical Abstract Service Registry Number; MRL, method reporting level; $\mu \mathrm{g} / \mathrm{L}$, micrograms per liter; P-Code, U.S. Environmental Protection Agency STORET code; NWQL, U.S. Geological Survey National Water Quality Laboratory; CLLE, Continiuous liquid-liquid extraction; GC/MS, gas chromatogrpahy/mass spectrometry; OGRL, U.S. Geological Survey Organic Geochemistry Research Laboratory; SPE, solid-phase extraction; HPLC/MS, high-performance liquid chromatogrpahy/mass spectrometry; ELISA, enzyme-linked immunosorbent assay; —, not applicable]

\begin{tabular}{|c|c|c|c|}
\hline Compound & CAS RN & $\begin{array}{c}\text { MRL } \\
(\mu \mathrm{g} / \mathrm{L})\end{array}$ & P-Code \\
\hline \multicolumn{4}{|c|}{ Pesticides and pesticide degradates (NWQL, Filtered, SPE, GC/MS) } \\
\hline Paraoxon-methyl & $950-35-6$ & 0.014 & 61664 \\
\hline Parathion-methyl & $298-00-0$ & 0.008 & 82667 \\
\hline Pendimethalin & $40487-42-1$ & 0.012 & 82683 \\
\hline Phorate oxygen analog & $2600-69-3$ & 0.027 & 61666 \\
\hline Phosmet & $732-11-6$ & 0.07 & 61601 \\
\hline Phosmet oxon & $3735-33-9$ & 0.0079 & 61668 \\
\hline Prometon & $1610-18-0$ & 0.012 & 4037 \\
\hline Prometryn & $7287-19-6$ & 0.006 & 4036 \\
\hline Terbufos oxygen analog sulfone & $56070-15-6$ & 0.045 & 61674 \\
\hline Terbuthylazine & $5915-41-3$ & 0.006 & 4022 \\
\hline Tribufos & $78-48-8$ & 0.018 & 61610 \\
\hline Trifluralin & $1582-09-8$ & 0.018 & 82661 \\
\hline \multicolumn{4}{|c|}{ Wastewater-indicator compounds (NWOL, Unfiltered, CLLE, GC/MS) } \\
\hline 1-Methylnaphthalene & $90-12-0$ & 0.02 & 81696 \\
\hline 2,2',4,4'-Tetrabromodiphenylether (PBDE 47) & $5436-43-1$ & 0.02 & 63147 \\
\hline 2,6-Dimethylnaphthalene & $581-42-0$ & 0.02 & 62805 \\
\hline 2-Methylnaphthalene & $91-57-6$ & 0.02 & 30194 \\
\hline 4-Nonylphenol diethoxylate $\left(\mathrm{NP}_{2} \mathrm{EO}\right)$ & $26027-38-2$ & 0.8 & 61703 \\
\hline 4-Nonylphenol monoethoxylate (NP $\mathrm{EO})$ & $104-35-8$ & 1.3 & 61704 \\
\hline 4-Octylphenol diethoxylate $\left(\mathrm{OP}_{2} \mathrm{EO}\right)$ & $26636-32-8$ & 0.1 & 62486 \\
\hline 4-Octylphenol monoethoxylate ( $\left.\mathrm{OP}_{1} \mathrm{EO}\right)$ & $26636-32-8$ & 0.3 & 62485 \\
\hline 4-tert-Octylphenol (OP) & $140-66-9$ & 0.11 & 62810 \\
\hline 5-Methyl-1H-benzotriazole & $136-85-6$ & 0.16 & 61944 \\
\hline Acetophenone & $98-86-2$ & 0.07 & 62811 \\
\hline Anthracene & $120-12-7$ & 0.01 & 34220 \\
\hline Anthraquinone & $84-65-1$ & 0.02 & 62813 \\
\hline Benzo[a]pyrene & $50-32-8$ & 0.01 & 34247 \\
\hline Benzophenone & $119-61-9$ & 0.08 & 62814 \\
\hline beta-Sitosterol & $83-46-5$ & 0.8 & 62815 \\
\hline beta-Stigmastanol & $19466-47-8$ & 0.8 & 61948 \\
\hline Bisphenol A & $80-05-7$ & 0.02 & 62816 \\
\hline Bromacil & $314-40-9$ & 0.08 & 30234 \\
\hline
\end{tabular}


Table 2. Pharmaceuticals and other organic wastewater compounds analyzed in water samples. - Continued

[CAS RN, Chemical Abstract Service Registry Number; MRL, method reporting level; $\mu \mathrm{g} / \mathrm{L}$, micrograms per liter; P-Code, U.S. Environmental Protection Agency STORET code; NWQL, U.S. Geological Survey National Water Quality Laboratory; CLLE, Continiuous liquid-liquid extraction; GC/MS, gas chromatogrpahy/mass spectrometry; OGRL, U.S. Geological Survey Organic Geochemistry Research Laboratory; SPE, solid-phase extraction; HPLC/MS, high-performance liquid chromatogrpahy/mass spectrometry; ELISA, enzyme-linked immunosorbent assay; —, not applicable]

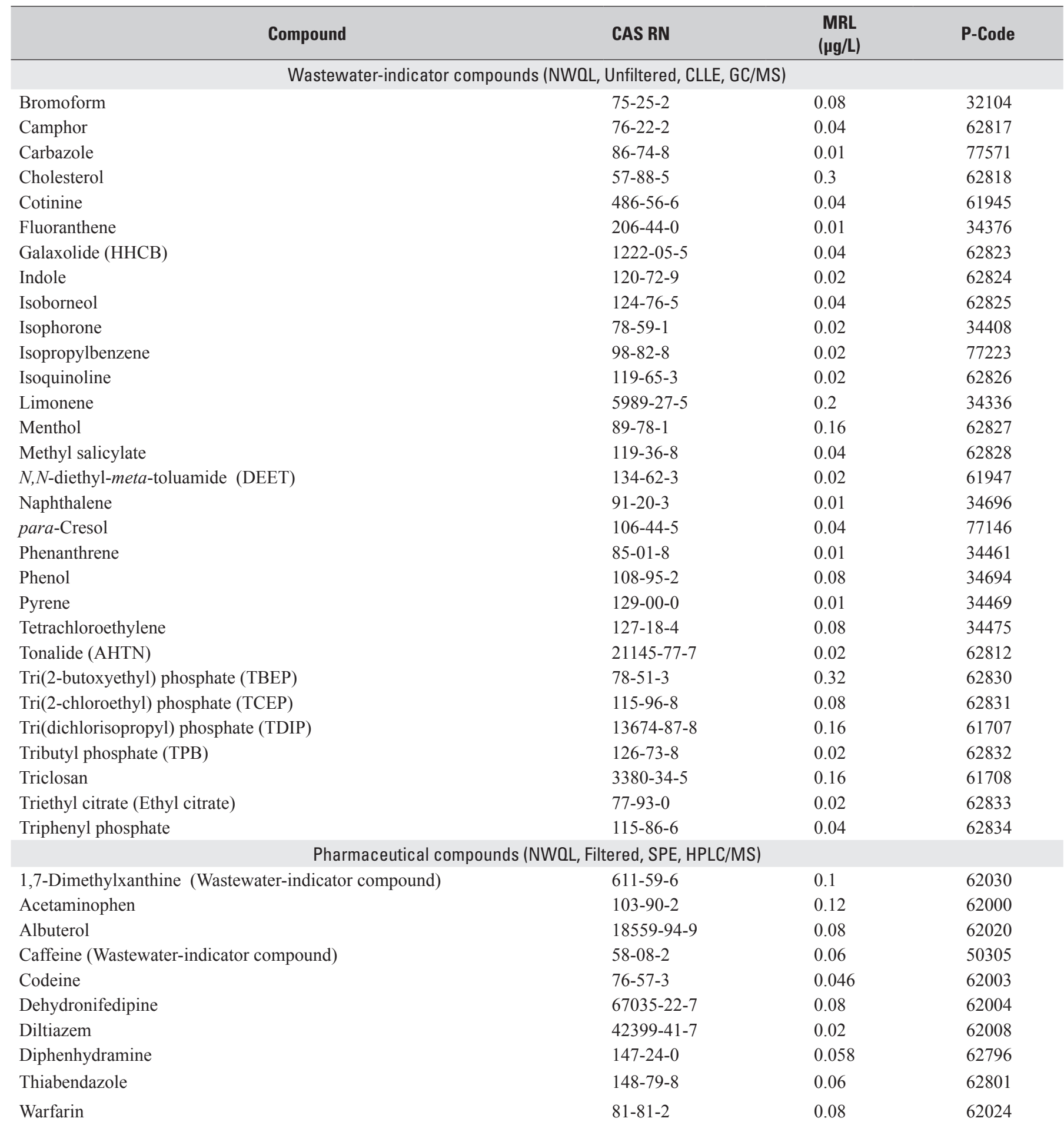


Table 2. Pharmaceuticals and other organic wastewater compounds analyzed in water samples. - Continued

[CAS RN, Chemical Abstract Service Registry Number; MRL, method reporting level; $\mu \mathrm{g} / \mathrm{L}$, micrograms per liter; P-Code, U.S. Environmental Protection Agency STORET code; NWQL, U.S. Geological Survey National Water Quality Laboratory; CLLE, Continiuous liquid-liquid extraction; GC/MS, gas chromatogrpahy/mass spectrometry; OGRL, U.S. Geological Survey Organic Geochemistry Research Laboratory; SPE, solid-phase extraction; HPLC/MS, high-performance liquid chromatogrpahy/mass spectrometry; ELISA, enzyme-linked immunosorbent assay; —, not applicable]

\begin{tabular}{|c|c|c|c|}
\hline Compound & CAS RN & $\begin{array}{c}\text { MRL } \\
(\mu g / L)\end{array}$ & P-Code \\
\hline \multicolumn{4}{|c|}{ Antibiotics (OGRL, Filtered, SPE, LC/MS) } \\
\hline Ciprofloxacin & $85721-33-1$ & 0.005 & - \\
\hline Enrofloxacin & $93106-60-6$ & 0.005 & - \\
\hline Lomefloxacin & $98079-51-7$ & 0.005 & - \\
\hline Ofloxacin & $82419-36-1$ & 0.005 & - \\
\hline Sarafloxacin & $98105-99-8$ & 0.005 & - \\
\hline \multicolumn{4}{|c|}{ Macrolides and degradation products } \\
\hline Azithromycin & $83905-01-5$ & 0.005 & - \\
\hline Erythromycin & $114-07-8$ & 0.008 & - \\
\hline \multicolumn{4}{|c|}{ Sulfonamides } \\
\hline Sulfachloropyridazine & $80-32-0$ & 0.005 & - \\
\hline Sulfadiazine & $68-35-9$ & 0.1 & - \\
\hline Sulfadimethoxine & $122-11-2$ & 0.005 & - \\
\hline Sulfamethoxazole & $723-46-6$ & 0.005 & - \\
\hline Sulfamethazine & $57-68-1$ & 0.005 & - \\
\hline Suflathiazole & $72-14-0$ & 0.05 & - \\
\hline \multicolumn{4}{|c|}{ Tetracyclines and degradation products } \\
\hline Chlortetracyline & $57-62-5$ & 0.01 & - \\
\hline Oxytetracycline & $79-57-2$ & 0.01 & - \\
\hline iso-Chlortetracycline & - & 0.01 & - \\
\hline \multicolumn{4}{|c|}{ Others } \\
\hline Carbamazepine (Pharmaceutical) & $298-46-4$ & 0.005 & - \\
\hline Chloramphenicol & $56-75-7$ & 0.1 & - \\
\hline Ibuprofen (Pharmaceutical) & $15687-27-1$ & 0.005 & - \\
\hline Lincomycin & $154-21-2$ & 0.005 & - \\
\hline Ormetoprim & 6981-18-6 & 0.005 & - \\
\hline Trimethoprim & $738-70-5$ & 0.005 & - \\
\hline \multicolumn{4}{|c|}{ Hormone (OGRL, Filtered, ELISA) } \\
\hline 17-beta-Estradiol (E2) & $50-28-2$ & 0.0015 & - \\
\hline
\end{tabular}


MC-1 is located directly adjacent to the HSWWTP, whereas MC-2 is approximately 1 mile (mi) downstream of MC-1. Canal water samples were also collected from a location in the Snapper Creek Canal (SC-1; fig. 1). This site was used as a background site because there are no known sources of wastewater to this canal. MC-1 and MC-2 were sampled in both the wet and dry season, while SC-1 was only sampled in the wet season. Bed sediment samples were collected at the same locations and times as canal water samples (MC-1, MC-2, and $\mathrm{SC}-1$ ), and analyzed for the wastewater-indicator compounds listed in table 3.

\section{Previous Studies}

Pharmaceuticals and other organic wastewater compounds are present in treated wastewater effluent and have been detected in surface water and groundwater near known sources of these contaminants in the United States and other parts of the world. Sando and others (2005) measured 50-60 pharmaceuticals and other organic wastewater compounds in treated wastewater effluent in South Dakota. Lietz and Meyer (2006) reported that 30-35 pharmaceuticals and other organic wastewater compounds were present in treated effluent from Miami-Dade County, Florida. These compounds also have been detected in surface waters that receive wastewater discharges and some of these compounds could be sufficiently mobile to be transported to the groundwater. Kolpin and others (2002) detected about 80 pharmaceuticals and other wastewater organic compounds in water from streams in the United States near known contaminant sources. Cordy and others (2004) determined in a laboratory study that some pharmaceuticals and other organic wastewater compounds, including carbamazepine, sulfamethoxazole, benzophenone, 5-methyl1H-benzotriazole, N-N-diethyl-meta-toluamide (DEET), tributylphosphate, and tri(2-chloroethyl) phosphate (TCEP), may potentially reach the groundwater. Studies by Heberer and others (2004) and Barnes and others (2004) indicated that some organic compounds, such as carbamazepine, DEET, and TCEP, can be transported within groundwater systems. Heberer and others (2004) detected in public-supply wells carbamazepine and several other pharmaceuticals, which were transported from a nearby stream by bank filtration. Barnes and others (2004) detected about 20 pharmaceuticals and other organic wastewater compounds, including DEET, in wells downgradient from a municipal landfill.

Pharmaceuticals include antibiotics, hormones, analgesics, opioids, barbiturates, stimulants and other chemicals that constitute a special class of organic compounds because they are specifically synthesized for human or veterinary use. As part of a larger group of "emerging contaminants," the USGS Toxic Substances Hydrology Program (http://toxics.usgs.gov/ index.html and http://toxics.usgs.gov/regional/emc/index.html) is engaged in a variety of research activities documenting the sources and persistence of pharmaceuticals in hydrologic systems (Barnes and others, 2008; Kinney and others, 2006;
Phillips and others, 2010), developing analytical techniques to detect and quantify these compounds (Cahill and others, 2004), and assessing the unintended effects of these compounds on organisms exposed to these compounds (Barber and others, 2007; Schultz and others, 2010; Vajda and others, 2008; Writer and others, 2001).

\section{Methods}

The following sections describe the methods used to collect and analyze data for this report. Methods described include sample collection and processing, analytical methods, quality assurance, and estimation of loads.

\section{Sample Collection and Processing}

All samples for this study were collected and processed according to standard USGS protocols (U.S. Geological Survey, variously dated). The 24-hr flow-weighted composite samples (2-hr intervals) were collected from the influent and effluent at the six plants (ND, CD1, CD2, SD1, SD2, and HSWWTP) using a Lagrangian sampling scheme (the initiation of sample collection at the effluent was lagged by hydraulic retention time, usually 2 to $4 \mathrm{hrs}$ ). At the MiamiDade WWTPs, facility personnel collected the samples in precleaned 1-liter (L) glass bottles and immediately stored them in a refrigerator at $4{ }^{\circ} \mathrm{C}$. At the HSWWTP, an ISCO (6712) automated sampler outfitted with fluoropolymer (Teflon ${ }^{\circledR}$ ) tubing was used to collect influent and effluent samples. Ice blocks were placed in the samplers to keep the samples chilled before being processed. At the end of each 24-hr sample period, water samples were transported on ice to the waterquality laboratory at the USGS Water Science Center in Fort Lauderdale, Fla., for processing. Samples for each respective site and type were then composited in either a 14-L Teflon ${ }^{\circledR}$ churn splitter or a 10 gallon (gal) stainless steel bucket. For those samples requiring filtration, water was passed through a 0.7 micrometer, baked $\left(450{ }^{\circ} \mathrm{C}\right.$ for $\left.8 \mathrm{hrs}\right)$, glass-fiber filter.

All equipment was decontaminated and the laboratory area was cleaned and lined with aluminum foil prior to processing, following previous methods (Lietz and Meyer, 2006). The initial step in the decontamination procedure involved cleaning the equipment with a dilute phosphate-free detergent. This was followed by rinsing with: (1) deionized water, (2) pesticide-grade methanol, and (3) pesticide-grade organic-free water. The equipment was then wrapped in aluminum foil and sealed in plastic bags prior to use. Disposable powderless nitrile gloves, a laboratory coat, and safety glasses were worn during the processing and decontamination procedure.

Groundwater samples from the three monitoring wells at the HSWWTP (fig. 2) were collected using a portable submersible pump. The pump was constructed of stainless steel and outfitted with Teflon ${ }^{\circledR}$ tubing to minimize cross contamination from one well site to another. A minimum of 


\section{Occurrence and Potential Transport of Selected Pharmaceuticals and Other Organic Wastewater Compounds}

Table 3. Wastewater-indicator compounds analyzed in bed sediment samples.

[CAS RN, Chemical Abstract Service Registry Number; MRL, method reporting level; $\mu \mathrm{g} / \mathrm{kg}$, micrograms per kilogram; P-Code, U.S. Environmental Protection Agency STORET code]

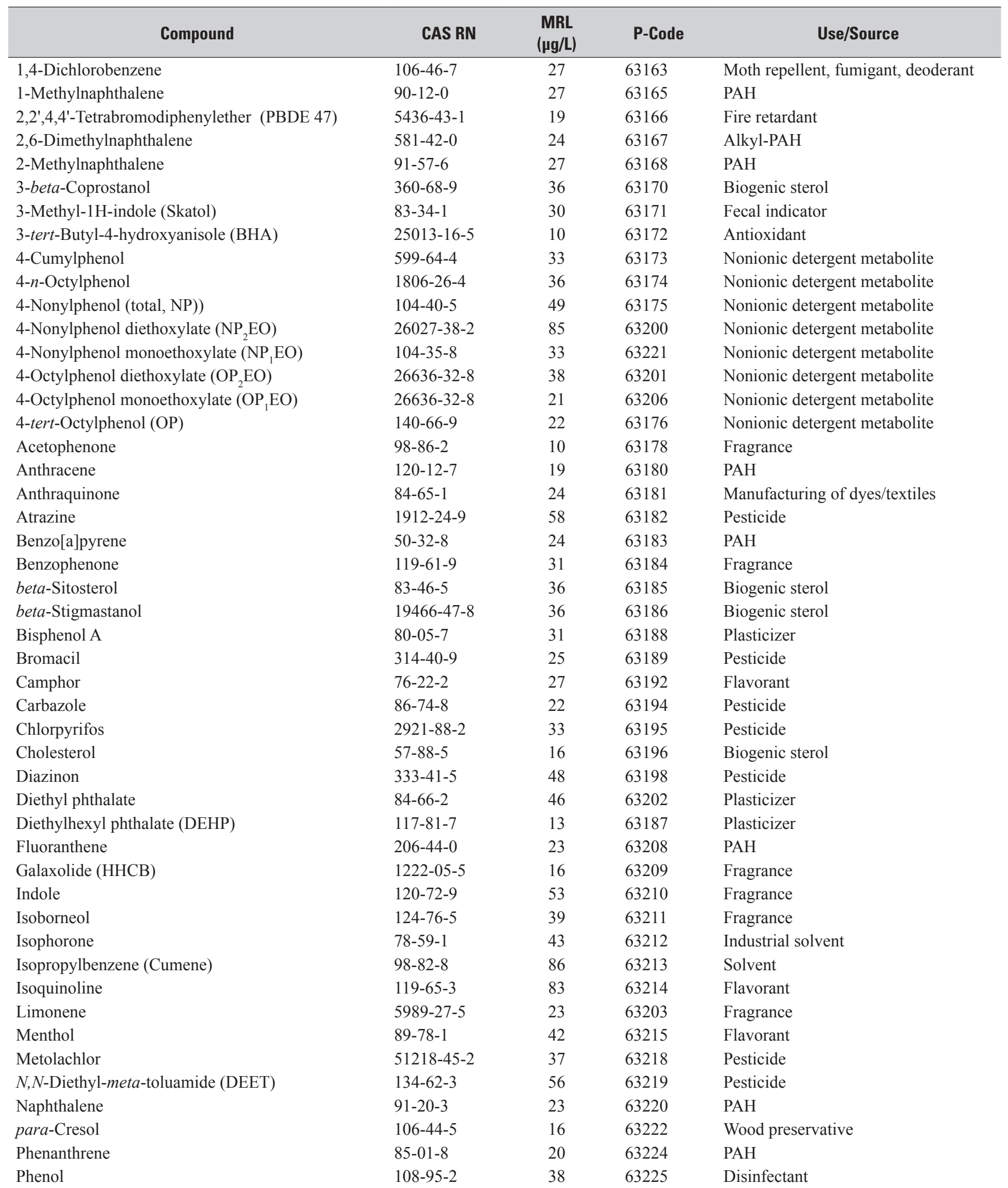


Table 3. Wastewater-indicator compounds analyzed in bed sediment samples.-Continued

[CAS RN, Chemical Abstract Service Registry Number; MRL, method reporting level; $\mu \mathrm{g} / \mathrm{kg}$, micrograms per kilogram; P-Code, U.S. Environmental Protection Agency STORET code]

\begin{tabular}{llcll}
\hline \multicolumn{1}{c}{ Compound } & \multicolumn{1}{c}{ CAS RN } & $\begin{array}{c}\text { MRL } \\
(\boldsymbol{\mu g} / \mathbf{L})\end{array}$ & P-Code & Use/Source \\
\hline Prometon & $1610-18-0$ & 44 & 63226 & Pesticide \\
Pyrene & $129-00-0$ & 20 & 63227 & PAH \\
Tonalide (AHTN) & $21145-77-7$ & 12 & 63179 & Fragrance \\
Tri(2-butoxyethyl) phosphate (TBEP) & $78-51-3$ & 98 & 63229 & Fire retardant \\
Tri(2-chloroethyl) phosphate (TCEP) & $115-96-8$ & 70 & 63230 & Fire retardant \\
Tri(dichloroisopropyl) phosphate (TDIP) & $13674-87-8$ & 73 & 63235 & Fire retardant \\
Tributyl phosphate (TBP) & $126-73-8$ & 39 & 63231 & Fire retardant \\
Triclosan & $3380-34-5$ & 49 & 63232 & Disinfectant \\
Triphenyl phosphate & $115-86-6$ & 46 & 63234 & Plasticizer \\
\hline
\end{tabular}

three casing volumes was purged from each well, and water samples were collected after field properties (temperature, $\mathrm{pH}$, specific conductance, and dissolved oxygen) had stabilized. To minimize contamination from the atmosphere, sample chambers were used while collecting and processing groundwater samples. Sampling equipment was cleaned immediately after sample collection using the decontamination procedure described in the previous paragraph.

Samples of canal water were collected using a depthintegrating Teflon ${ }^{\circledR}$ sampler from 5-10 verticals and composited in a 14-L Teflon ${ }^{\circledR}$ churn splitter. Samples of bed sediments were collected using a stainless steel Ekman grab sampler (model \#316ss). Each bed sediment sample consisted of approximately 35 cubic inches of sediment from the top 4 in. of the soil column. To minimize cross contamination from one canal site to another, both samplers were decontaminated immediately before and after the collection of each sample using the decontamination procedure described previously.

Samples collected for analysis of low levels (parts per trillion) of pharmaceuticals and other organic wastewater compounds are susceptible to contamination because these compounds are found in many products that are routinely used by field personnel. To ensure sample integrity during sample collection and preparation, field personnel avoided contact with or consumption of products that contain the compounds targeted for analysis. These products included soaps and detergents, insect repellents, fragrances, sunscreen, caffeine, and tobacco products. Field personnel also avoided contact with the following pharmaceuticals: prescription drugs, medications and hormonal substances, nonprescription medications, and selected human and veterinary antibiotics. Powderless nitrile gloves were frequently changed during sampling activities and bottling to prevent contamination. Direct contact between samples and clothing also was avoided during sampling and processing activities.

\section{Analytical Methods}

The concentrations of 210 organic compounds were determined using six different analytical methods. The 210 compounds included semivolatile organic compounds (SVOCs), pesticides and pesticide degradates, wastewaterindicator compounds, pharmaceuticals, antibiotics, and one hormone (17-beta-estradiol, E2) (table 2). The analytical procedures used for the determination of SVOCs, pesticides and pesticide degradates, wastewater-indicator compounds, and pharmaceuticals in water samples are approved USGS methods (Fishman, 1993; Zaugg and others, 1995; Zaugg and others, 2006; and Furlong and others, 2008). Antibiotics were analyzed using a method modified from Meyer and others (2007). The procedure used for the determination of E2 in water samples is a provisional research method not yet approved by the USGS.

The SVOCs, pesticides and pesticide degradates, wastewater-indicator compounds, and pharmaceuticals were analyzed at the USGS National Water Quality Laboratory (NWQL) in Denver, Colo. SVOCs were extracted from unfiltered water samples using continuous liquid-liquid extraction (CLLE). The extracts were analyzed for 46 SVOCs (table 2) and 5 surrogate compounds by gas chromatography/mass spectrometry (GC/MS) methods (Fishman 1993). Pesticides and pesticide degradates were extracted from filtered water samples using C-18 solid-phase extraction (SPE) cartridges. The extracts were analyzed for 64 pesticides and pesticide degradates (table 2) and 2 surrogate compounds by capillarycolumn GC/MS methods (Zaugg and others, 1995). Wastewater-indicator compounds were extracted from unfiltered water samples using CLLE. The extracts were analyzed for 56 wastewater-indicator compounds (table 2) and 4 surrogate compounds by GC/MS methods (Zaugg and others, 2006). Pharmaceuticals were extracted from filtered water samples 
using chemically modified styrene-divinylbenzene resin-based SPE cartridges. The extracts were analyzed for 8 pharmaceuticals, 2 wastewater-indicator compounds (caffeine and the caffeine metabolite, 1,7-dimethylxanthine) (table 2), and 2 surrogate compounds by high-performance liquid chromatography/ mass spectrometry (HPLC/MS) methods (Furlong and others, 2008). Wastewater-indicator compounds were extracted from sediment samples using pressurized solvent extraction followed by SPE. The extracts were analyzed for 57 wastewaterindicator compounds (table 3 ) and 3 surrogate compounds by GC/MS methods (Burkhardt and others, 2006).

A total of 31 antibiotics, 2 pharmaceuticals (carbamazepine and ibuprofen), 3 surrogate compounds, and E2 were analyzed at the USGS Organic Geochemistry Laboratory (OGRL) in Lawrence, Kansas. The antibiotics and pharmaceuticals were analyzed using on-line solid-phase extraction (OLSPE) and liquid chromatography/tandem mass spectrometry (LC/MS/ MS) modified from the OLSPE LC/MS method of Meyer and others, 2007. The analysis of E2 in filtered water samples was performed using commercially available magnetic-particle enzyme-linked immunosorbent assay (ELISA) kits (Abraxis, Warminster, Pennsylvania). Generally, the results from the ELISA method in complex matrices such as the ones analyzed in this study should be considered semi-quantitative (Farre and others, 2006) and, therefore, interpreted with some caution.

Many of the concentrations reported herein were below analytical method reporting levels (generally less than $0.4 \mu \mathrm{g} / \mathrm{L}$ ); however, because they met qualitative criteria used for compound identification (chromatographic retention times, full-scan mass spectra, and ion abundance ratios), they were reported by the laboratory as estimated (E) values. Other factors that could lead to an estimated value include: (1) the sample matrix interfered with measurement of the compound; (2) surrogate recoveries (described in the next section) indicated poor performance during the analysis; or (3) the compound consistently has poor recoveries and concentrations are always reported as estimated (S. Smith, U.S. Geological Survey, oral commun., 2010).

\section{Quality Assurance}

Water samples collected for analysis of pharmaceuticals and other organic wastewater compounds require special considerations related to quality-assurance (QA). In this study, QA samples were collected to assess laboratory performance and to help identify potential contamination problems associated with field and/or laboratory methods. These QA samples consisted of equipment blank, field blank, replicate, and matrix spike samples that were collected, processed, and analyzed using methods similar to those used for the environmental samples. Additionally, surrogate compounds were added to all water samples sent to the NWQL to evaluate method performance for individual samples. All quality-assurance results are included in appendixes 1 and 2 .
Two field blanks and one equipment blank were collected to ensure that the equipment was adequately cleaned prior to sample collection and that collection and processing did not result in contamination. The blanks were collected by passing laboratory-grade organic-free water through the equipment used for the collection and processing of environmental samples. The two field blanks (one for the churn and one for the groundwater pump) were collected in the field immediately prior to collecting the environmental sample. The equipment blank was collected in the laboratory prior to using any of the sampling and processing equipment (for example, the ISCO pump and churn). Each blank was subject to the same sample processing, handling, and equipment as the environmental samples. The majority of the compounds analyzed were not detected in the blanks collected in this study; only nine compounds (4-nonylphenol monoethoxylate $\left(\mathrm{NP}_{1} \mathrm{EO}\right)$, benzophenone, galaxolide (HHCB), DEET, phenol, TCEP, triclosan, triethyl citrate and triphenyl phosphate) were detected in at least one blank sample (app. 1). Furthermore, concentrations in blanks were typically an order of magnitude lower than concentrations detected in associated environmental samples verifying the general effectiveness of the sampling protocols used in this study. Phenol was the only compound detected in a blank sample above its method reporting level (MRL) $(0.51 \mu \mathrm{g} / \mathrm{L}$, churn blank). Therefore, environmental concentrations of phenol within 10 times the concentration in the churn blank were not reported.

Replicate samples (one canal, one influent, and one effluent) were collected and analyzed to determine the variability in sample collection and processing procedures and to examine the effect these variations can have on evaluating the precision of ambient environmental concentrations. Replicate samples were collected immediately after environmental samples were collected, using the same equipment. The variability of chemical analysis and consistency of sample collection and processing were determined by calculating the relative percent difference (RPD) between the two samples. The RPD is defined as:

$$
\operatorname{RPD}=(d / \bar{x})^{\prime} 100
$$

where

$d \quad$ is the difference between the replicate sample and environmental sample, and

$\bar{x} \quad$ is the average concentration of the two samples.

Generally, an RPD of 20 percent or less indicates an acceptable level of precision. However, for very small concentrations near the MRL, the RPD can be higher than 20 percent and still be considered reasonable due to the limits of resolution (Taylor, 1987). Median RPDs for canal, influent, and effluent water were 4.9 percent (ranging from 0.0 to 22.2 percent), 31.5 percent (ranging from 0.8 to 140 percent), 
and 20.3 percent (ranging from 0.0 to 167 percent), respectively. There were 14 instances ( 4 canal, 5 influent, and 5 effluent) where a specific compound was detected in only one of the paired replicate samples. Replicate data indicate that there is a higher degree of uncertainty in influent and effluent concentrations compared to canal concentrations.

In an effort to evaluate the impact of matrix effects on overall analytical performance, two environmental samples (one influent and one effluent) were spiked with target analytes. Median matrix spike recoveries for individual compounds in influent and effluent spike samples were 79.7 (ranging from -508 to 757 percent) and 88.3 percent (ranging from 0.0 to 213 percent), respectively (app. 1). Spike recoveries for 76 compounds in the influent spiked sample and 35 compounds in the effluent spiked sample were outside the expected spike recovery range for that particular compound (values shown in red type in app. 1). However, the expected ranges were established using spike results from organic-free water samples and there are no established matrix-specific control limits. Additionally, if sample matrices have environmental concentrations that are higher than the spiked concentrations added to them, which was the case with numerous compounds in both the influent and effluent spiked sample, achieving acceptable spike recoveries might not be possible. Generally, the matrix spike results indicated there were larger matrix effects in influent samples than in effluent samples. Three compounds (chloramphenicol, ibuprofen, and virginiamycin) were not detected in either spiked sample, which suggests the analytical and(or) sampling method did not perform well for the low-level detection of these three compounds.

Surrogate compounds were added to samples at the NWQL to monitor the performance of the analytical processes and extraction steps. The acceptable range for spike recovery established by the NWQL (app. 2) is based on spike recoveries of past sample analyses and is recalculated periodically as more batches of samples are analyzed (S. Abney, U.S. Geological Survey, National Water Quality Laboratory, Denver, Colo., written commun., 2011). Anomalous recovery values that exceed this range can indicate possible analytical problems for individual samples. Alpha-HCH-d6 and diazinon-d10, two surrogate compounds, were added to samples analyzed for pesticides and pesticide degradates. The median apparent recoveries of alpha-HCH-d6 and diazinond10 were 91.3 percent (ranging from 74.2 to 175 percent) and 137 percent (ranging from 91.3 to 184 percent), respectively (app. 2). Carbamazepine-d10 and ethylnicotinate-d4, two surrogate compounds, were added to samples analyzed for pharmaceuticals (app. 2). The median apparent recoveries of carbamazepine-d10 and ethylnicotinate-d4 were 20.1 percent (ranging from 7.2 to 119 percent) and 64.5 percent (ranging from 24.3 to 97.2 percent), respectively (app. 2). Bisphenol A-d3, caffeine-C13, decafluorobiphenyl and fluoranthened10, four surrogate compounds, were added to samples analyzed for wastewater-indicator compounds (app. 2). The median apparent recoveries of bisphenol A-d3, caffeine-C13, decafluorobiphenyl and fluoranthene-d 10 were 57.3 percent (ranging from 0.0 to 134 percent), 63.2 percent (ranging from 0.0 to 97.4 ), 42.6 percent (ranging from 14.6 to 77.7 percent), and 58.1 percent (ranging from 10.9 to 85.5 percent), respectively (app. 2). 2,4,6-tribromophenol, 2-fluorobiphenyl, 2-fluorophenol, nitrobenzene-d5, phenol-d5, and terphenyld14, six surrogate compounds, were added to samples analyzed for SVOCs (app. 2). The median apparent recoveries of 2,4,6-tribromophenol, 2-fluorobiphenyl, 2-fluorophenol, nitrobenzene-d5, phenol-d5, and terphenyl-d14 were 90.4 percent (ranging from 21.1 to 136), 73.6 percent (ranging from 22.0 to 93.5 ), 59.1 percent (ranging from 14.8 to 101 percent), 90.8 percent (ranging from 28.6 to 124 percent), 53.7 percent (ranging from 15.1 to 110 percent), and 45.4 percent (ranging from 16.8 to 92.1 percent), respectively (app. 2). Meclocycline, nalidixic acid, and sulfamethazine${ }^{13} \mathrm{C}_{6}$, were added to each water sample analyzed for antibiotics. The median apparent recoveries of meclcycline, nalidixic acid, and sulfamethazine $-{ }^{13} \mathrm{C}_{6}$ were 74.4 (ranging from 9.6 to 230 percent), 162 (ranging from 58 to 1,492 percent), and 98.2 (ranging from 11.6 to 240 percent), respectively. The high range in the apparent recoveries for the naxidilic acid indicates that its response was enhanced in the influent and effluent matrices relative to its internal standard.

\section{Estimation of Loads}

Daily loads (total mass of compounds discharged in the effluent in one day) were calculated for influent and effluent samples to compare among seasons and to provide information on the estimated quantity of pharmaceuticals and other organic wastewater compounds discharged to the environment from WWTPs in Miami-Dade County. Loads were calculated by multiplying the average flow during each $24-\mathrm{hr}$ sampling period by total concentrations of constituents in the effluent and by a conversion factor $\left(8.34 \times 10^{-9}\right)$ to convert million gallons per day and micrograms per liter to pounds per day. Concentrations reported as less than the MRL were censored to 0.0 and not used in the load calculations.

Erroneous load estimates can be caused by two factors. Firstly, many of the concentrations of pharmaceuticals and other organic wastewater compounds were reported as estimated values (E) by the laboratory. Multiplying the concentrations by flow, which in some cases was very large, might result in substantially increasing the effect of analytical error in the reported load estimates. Secondly, several of the estimated loads were calculated using results from filtered water methods (that is, pesticides, pharmaceuticals, antibiotics, and E2), which does not take into account the fraction of compounds in the non-aqueous phase, thus underestimating the total load. Although there might be error in the absolute value of the load estimates, they can provide relative estimates to compare among sites and sampling periods (Sando and others, 2005). 


\section{Pharmaceuticals and Other Organic Wastewater Compounds Detected in Wastewater Samples}

Influent and effluent samples were collected from the six plants in Miami-Dade County to determine total loads in both the influent and effluent and percent reduction of each target compound through the treatment process. Samples were collected and analyzed from each WWTP on two occasions, once in the dry season and once in the wet season, to determine seasonal differences in concentrations. The influent and effluent samples collected from CD1 in the dry season for the analysis of wastewater-indicator compounds were lost during shipment; therefore, results for those compounds are not available. Sampling dates and average flow during sampling at each plant are listed in table 1. Summarized results (including minimum, median, maximum concentrations detected, and number of detections) for wet-season and dry-season sampling as well as combined sampling are listed in tables 4 and 5.

\section{Pharmaceuticals and Other Organic Wastewater Compounds Detected in 24-Hour Flow-Weighted Influent Composite Samples}

Influent samples at each plant contained a complex mixture of organic compounds reflecting the diversity of incoming domestic, municipal, and industrial waste, as well as stormwater runoff. Compounds detected in influent samples included: 20 SVOCs, 12 pesticides, 52 wastewater-indicator compounds, 5 pharmaceuticals, 14 antibiotic, and E2 (table 4; app. 3). Wastewater-indicator compounds accounted for the majority of the total concentration (equal to the sum of all detected concentrations of all analytes) in each effluent sample followed by pharmaceuticals and SVOCs (fig. $3 A$; app. 4). Pesticides and pesticide degradates, antibiotics, and E2 accounted for less than 2 percent of the total concentration in each influent sample. The total concentrations in influent samples collected in the dry season were generally 10 to 30 percent higher than samples collected in the wet season (fig. $3 A$; app. 4). The lower total concentrations in influent samples collected in the wet season most likely reflect the higher fraction of stormwater runoff in wastewater during the wet season than during the dry season. Generally, stormwater runoff would be expected to contain smaller concentrations of many of the target compounds (Wilkison and others, 2006), which typically occur more frequently in household and industrial wastewaters that are discharged directly to the sewer system. Estimated loads to each plant ranged from 14.6 to 403.9 pounds per day $(\mathrm{lb} / \mathrm{d})$ and were higher in the wet season at five of the six plants (fig. 3B; app. 4). For graphical purposes, E2 was not included in figure 3.

Among the 20 SVOCs detected, diethylhexyl phthalate (DEHP), a widely used plasticizer, showed the largest concentration range ( 5.3 to $270 \mu \mathrm{g} / \mathrm{L})$ and highest median concentration $(12 \mu \mathrm{g} / \mathrm{L})$ (table 4$)$. The three SVOCs 1,4-dichlorobenzene (ranging in concentration from 0.84 to $15 \mu \mathrm{g} / \mathrm{L}$ ), 2,4-dichlorophenol (ranging in concentration from 0.10 to $1.6 \mu \mathrm{g} / \mathrm{L}$ ), and diethyl phthalate (ranging in concentration from 2.2 to $10 \mu \mathrm{g} / \mathrm{L}$ ), were detected in every influent sample. The four compounds 1,2-dichlorobenzene, 2-chlorophenol, benzo[k]fluoranthene, and $N$-nitrosodiphenylamine, were only detected in dry-season influent samples.

Scattered occurrences of 12 pesticides and pesticides degradates were detected near reporting levels in influent samples; carbaryl was the only pesticide detected at concentrations greater than $0.2 \mu \mathrm{g} / \mathrm{L}$. Fipronil, a broad spectrum insecticide, and two fipronil degradates (desulfinylfipronil and fipronil sulfide) were the only pesticides detected in more than 50 percent of influent samples collected, with concentrations of the three constituents ranging from 0.005 to $0.15 \mu \mathrm{g} / \mathrm{L}$ (table 4). Generally, pesticides were detected more frequently in influent samples collected in the wet season (summer months) with four pesticides (chlorpyrifos, fipronil sulfone, methidathion, and terbuthylazine) detected in wet-season influent samples only. The higher fraction of stormwater runoff in wastewater during the wet season than during the dry season might contribute to the higher frequency of detection of pesticides during the wet season. The higher detection frequency of pesticides and pesticides degradates in the wet season could reflect higher pesticide usage during warmer months of the wet season.

Among the 52 wastewater-indicator compounds detected, the two biogenic sterols, cholesterol and 3-beta-coprostanol, had the highest maximum concentrations (130 and $120 \mu \mathrm{g} / \mathrm{L}$, respectively) and the highest median concentrations (91 and $79 \mu \mathrm{g} / \mathrm{L}$, respectively), while the detergent metabolite 4-nonylphenol (NP, total) showed the largest concentration range (3.8 to $120 \mu \mathrm{g} / \mathrm{L}$ ). The median concentrations for individual compounds were slightly higher (but not statistically different) in the dry season compared to the wet season (table 4). The six wastewater-indicator compounds $(2,2$ ', 4,4 '-tetrabromodiphenylether, 3,4-dichlorophenyl isocyanate, 4-n-octylphenol, anthraquinone, bromacil, and isoquinoline) were not detected in influent samples (app. 3), although the poor recovery of 3,4 -dichlorophenyl isocyanate $(0.0$ percent) in the influent spike sample (app. 1) affected the probability for its detection.

Among the five pharmaceuticals detected, only one (acetaminophen) was detected in every influent sample (ranging from 18 to $120 \mu \mathrm{g} / \mathrm{L}$; table 4). Carbamazepine, an anticonvulsant, was detected in all but one influent sample at low concentrations (ranging from 0.029 to $0.23 \mu \mathrm{g} / \mathrm{L}$ ). Albuterol, dehydronifedipine, diltiazem, diphenhydramine, and warfarin were not detected in influent samples (app. 3), although the poor recovery of diltiazem ( 0 percent $)$ and diphenhydramine (0 percent) in the influent spike sample (app. 1) affected the probability for their detection.

Among the 14 antibiotics detected, 6 (ciprofloxacin, erythromycin- $\mathrm{H}_{2} \mathrm{O}$, ofloxacin, sulfamethoxazole, tetracycline and trimethoprim) were detected in every influent sample (ranging from 0.009 to $1.7 \mu \mathrm{g} / \mathrm{L}$ ). Sulfamethoxazole, a 


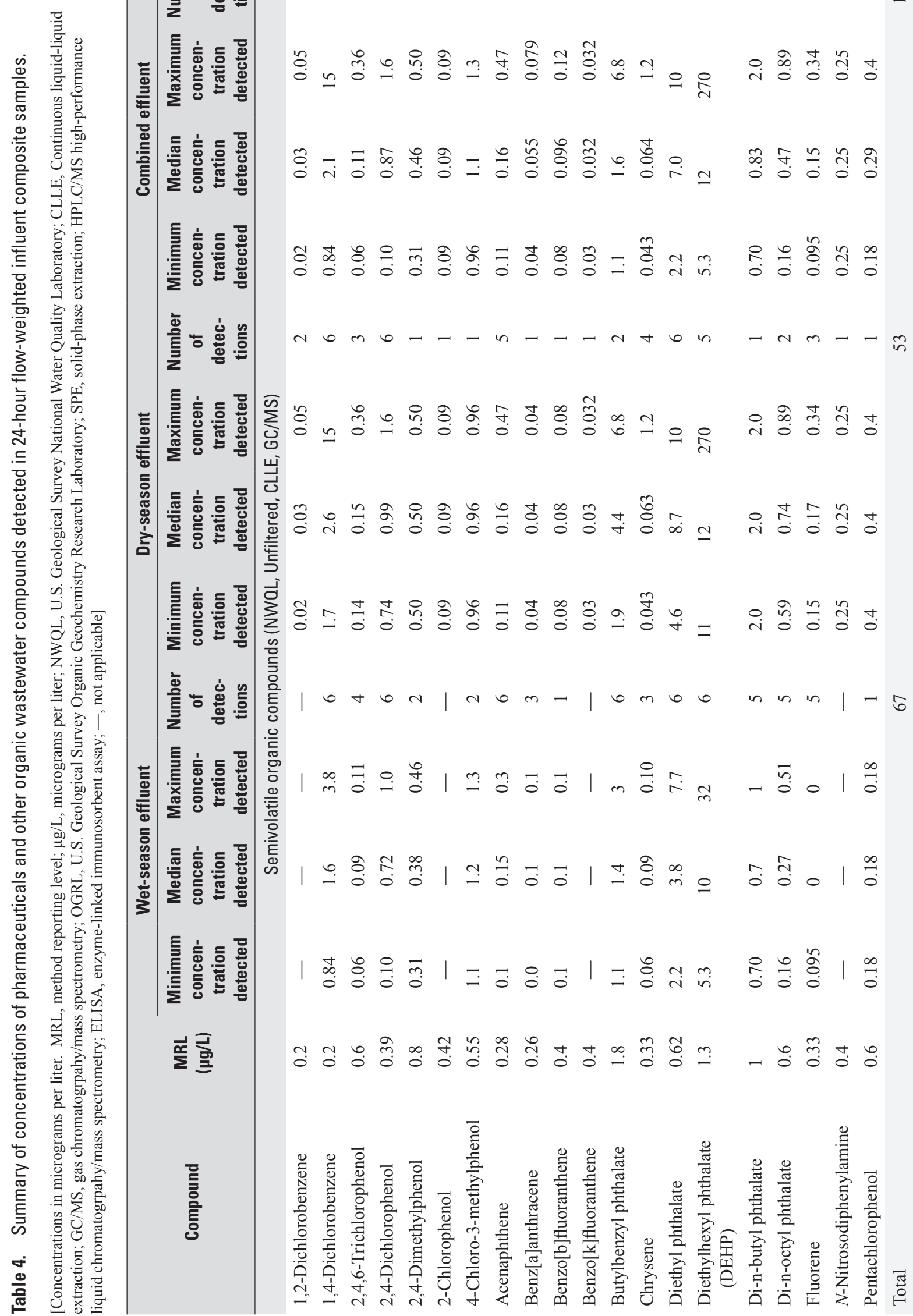




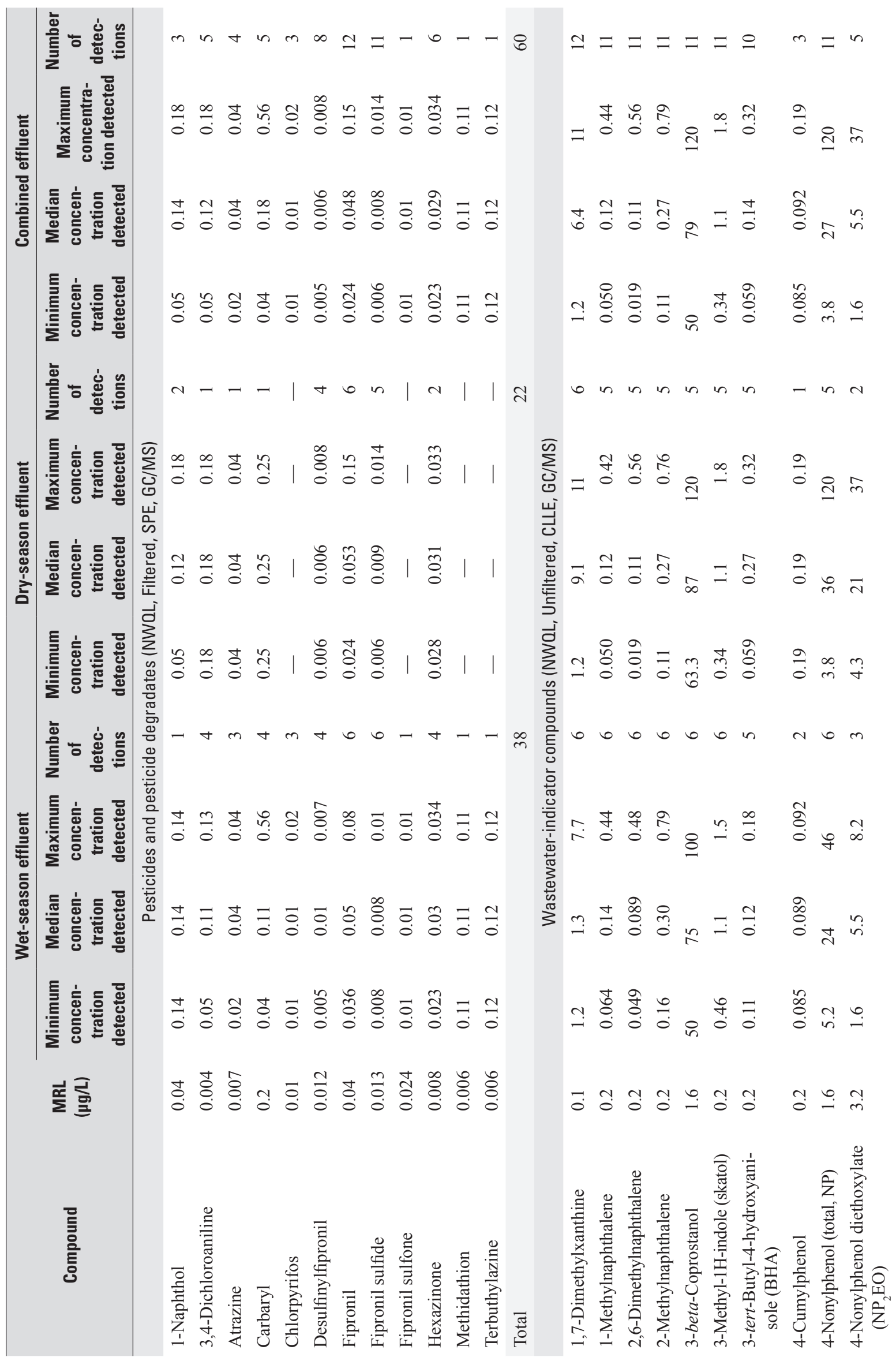



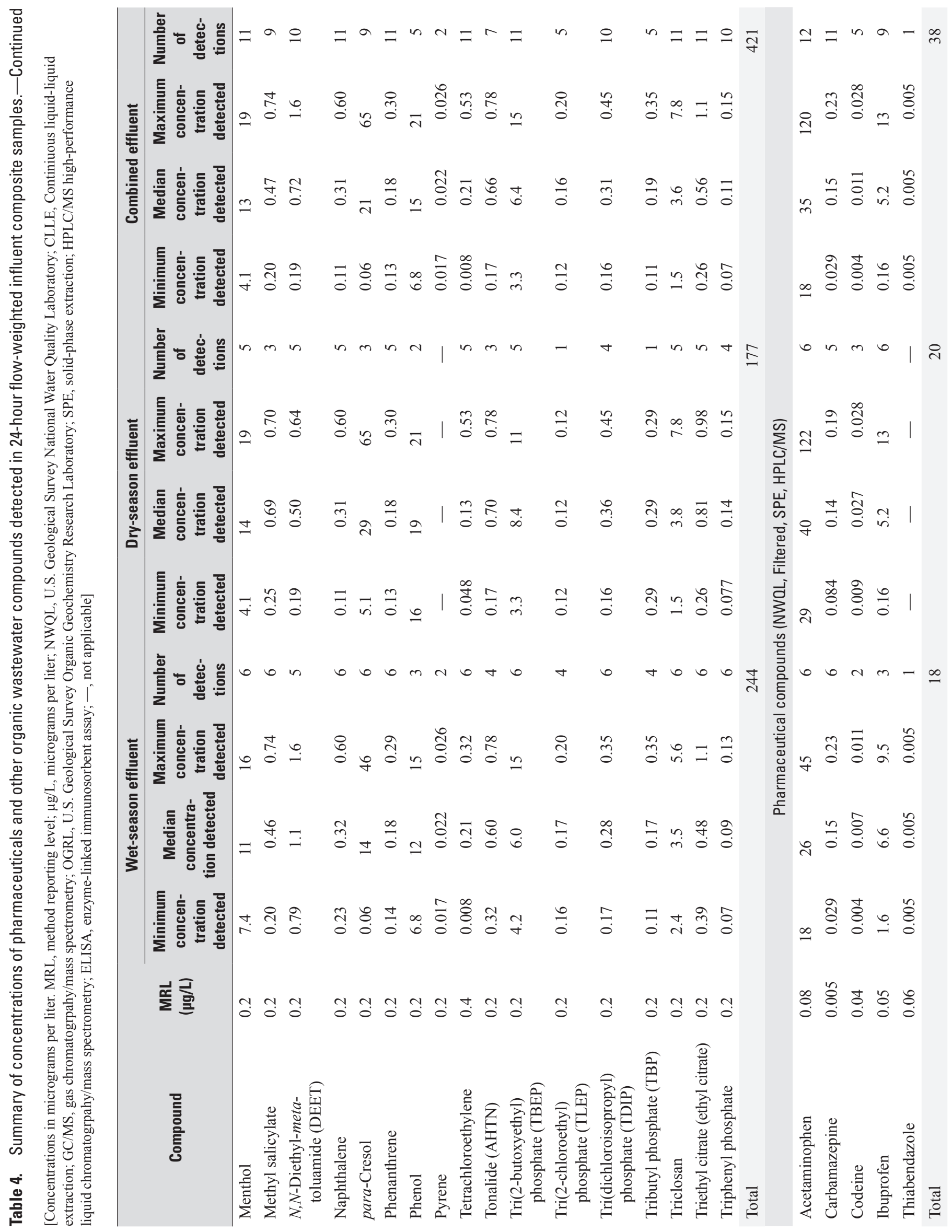


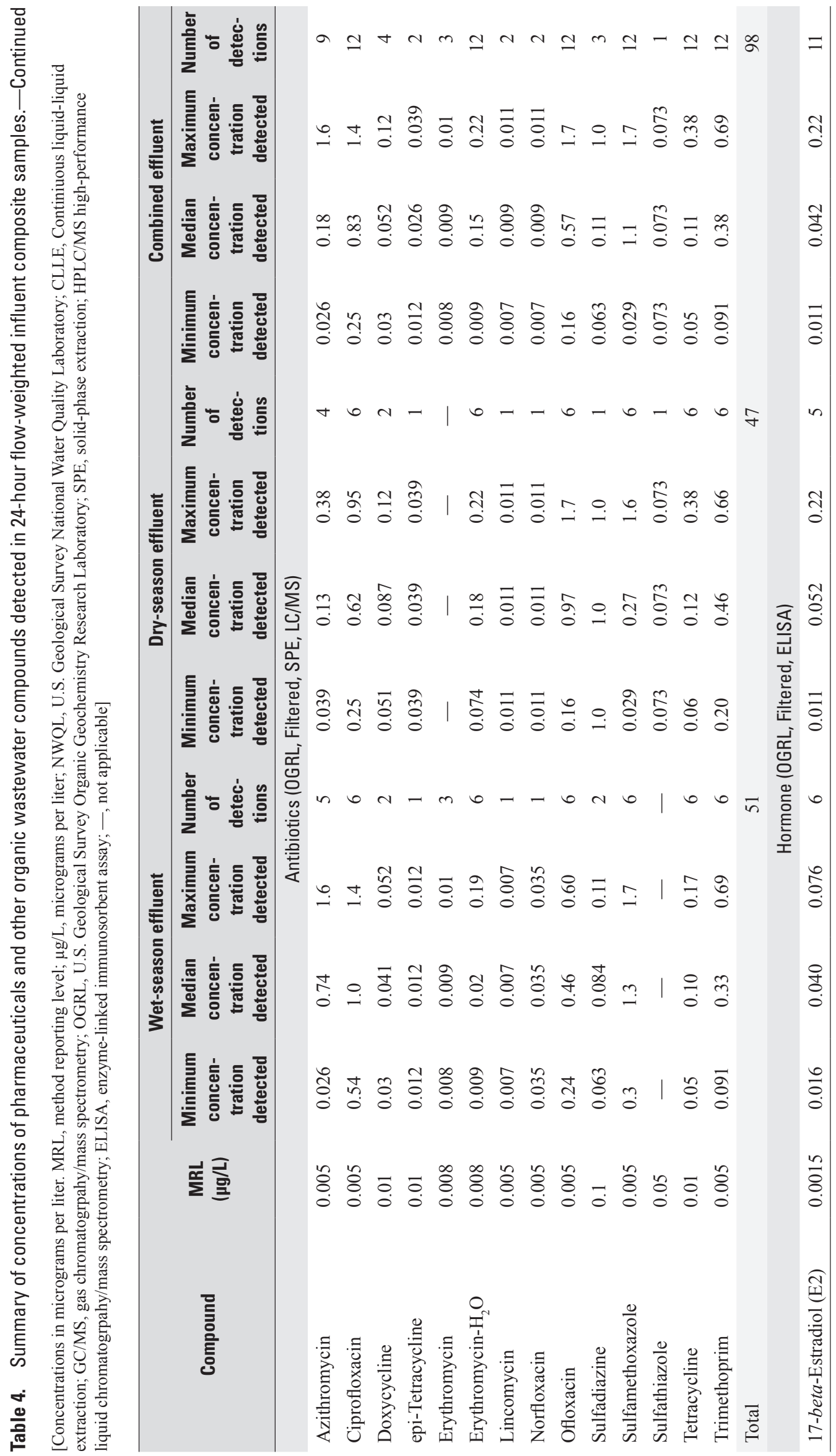




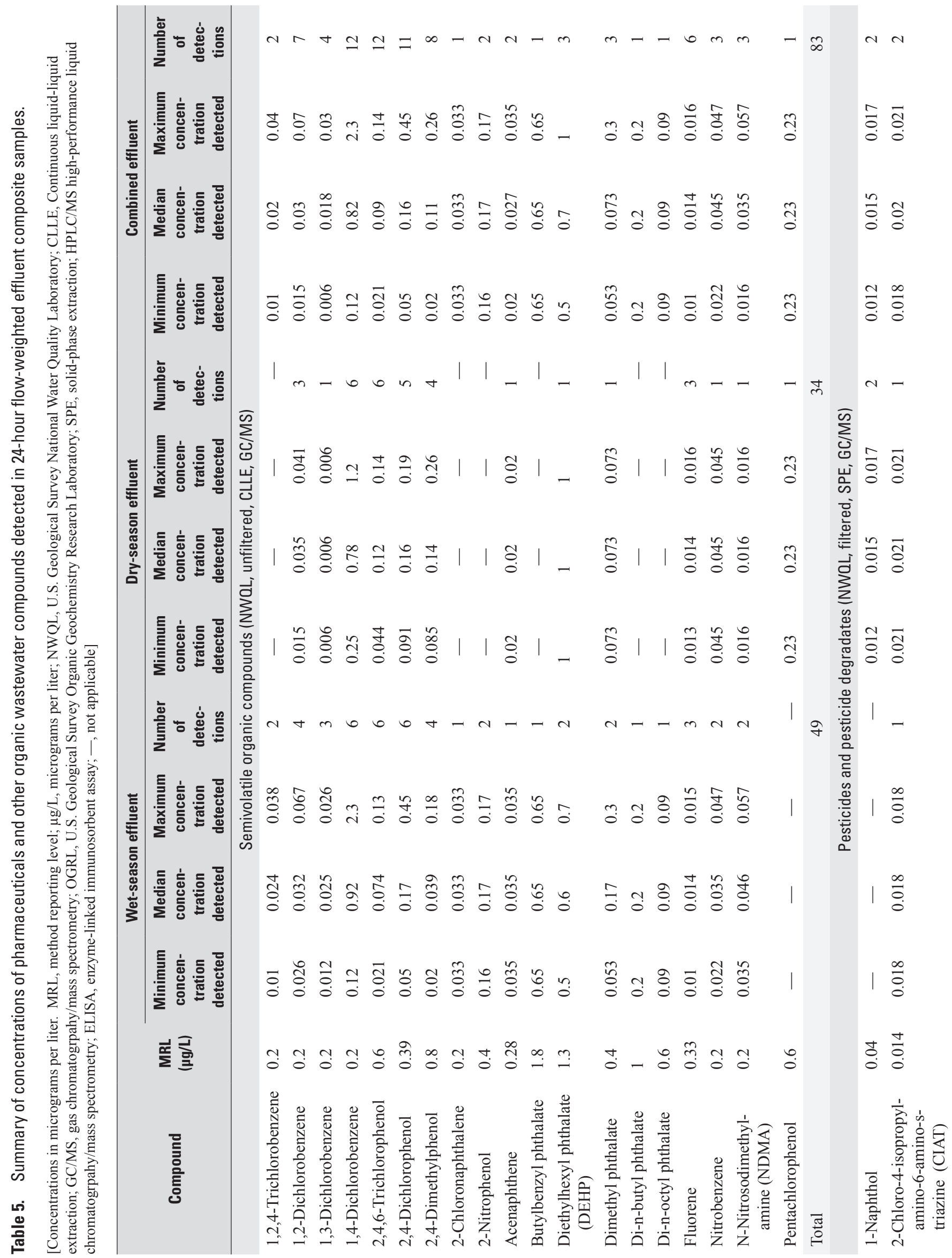




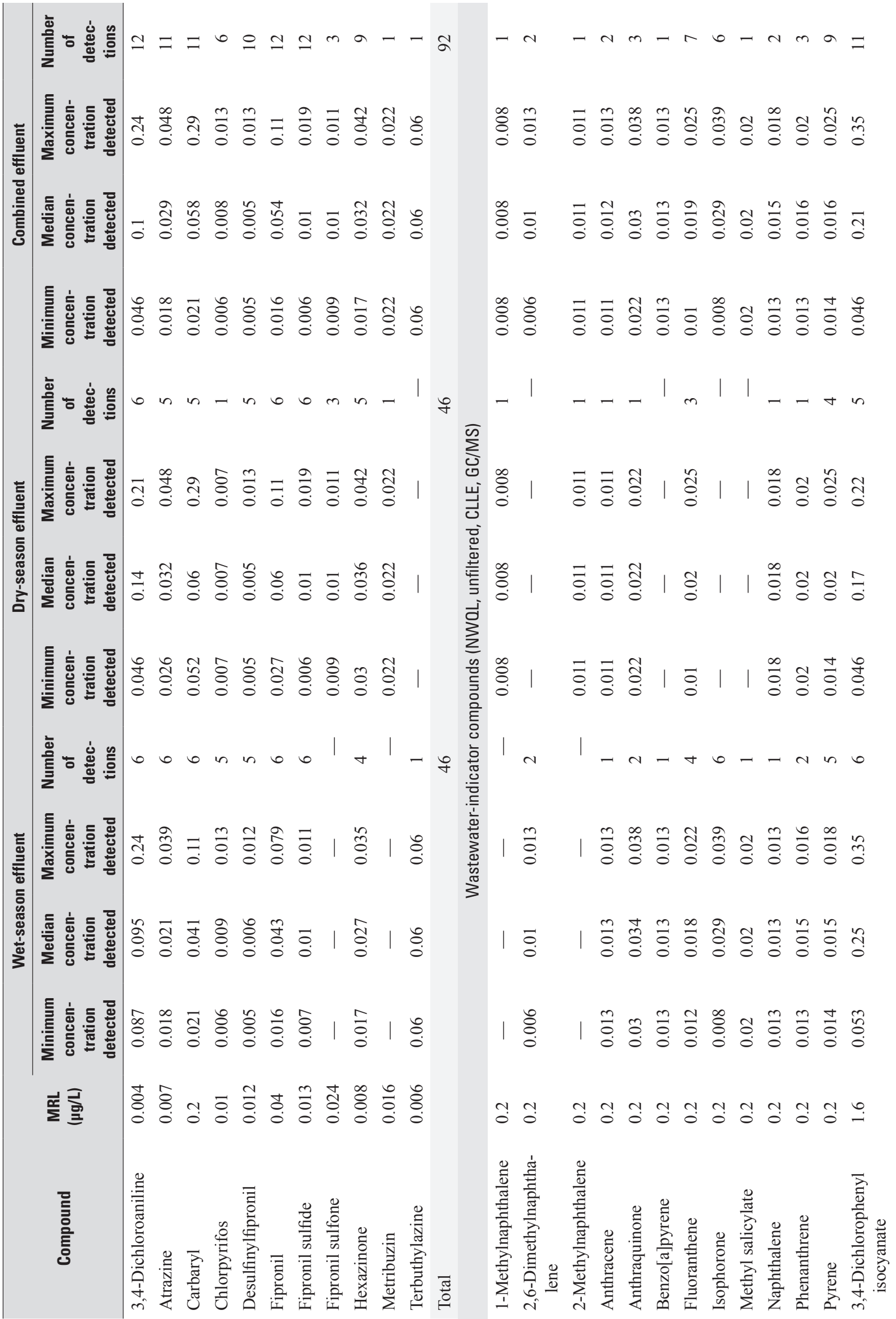




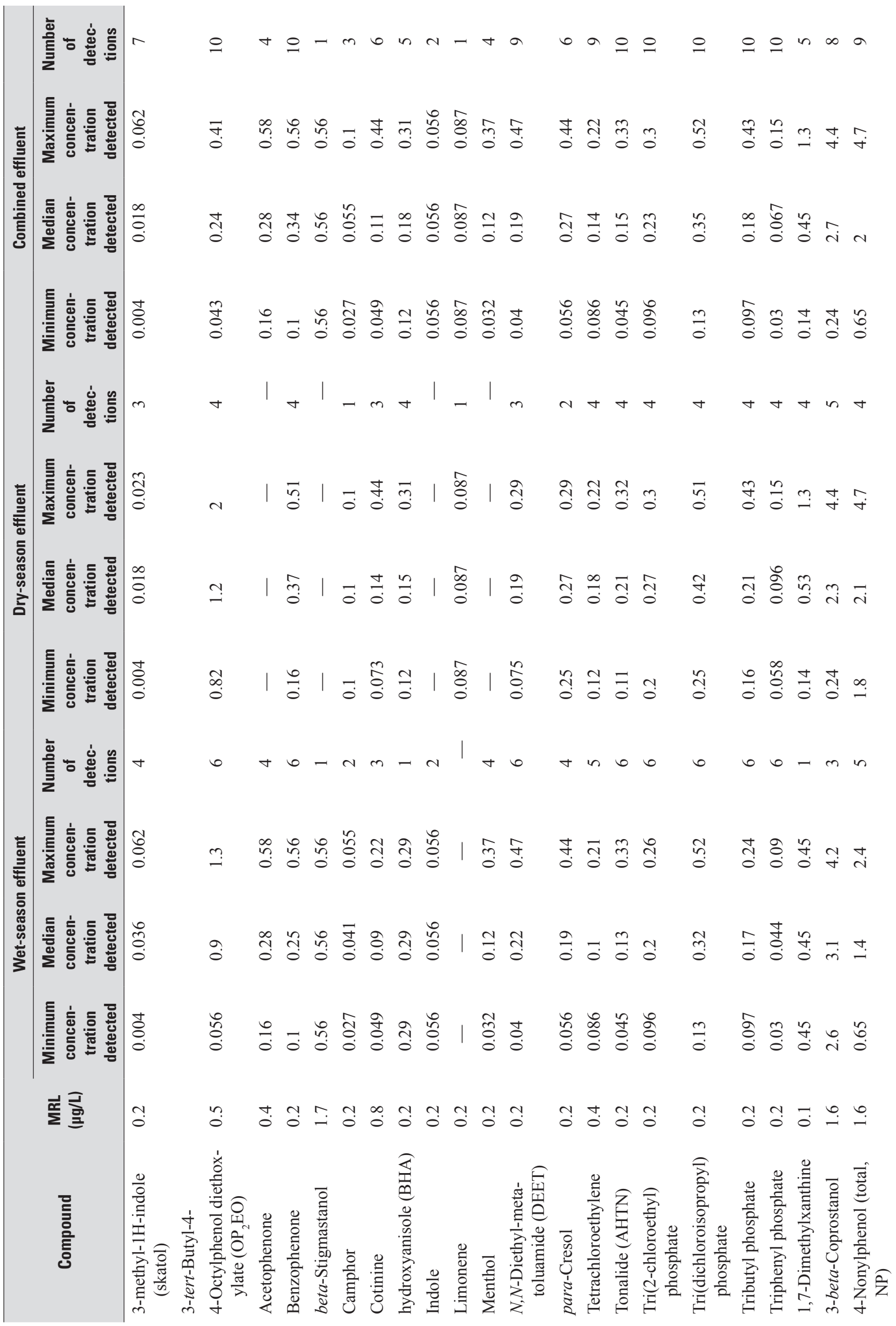




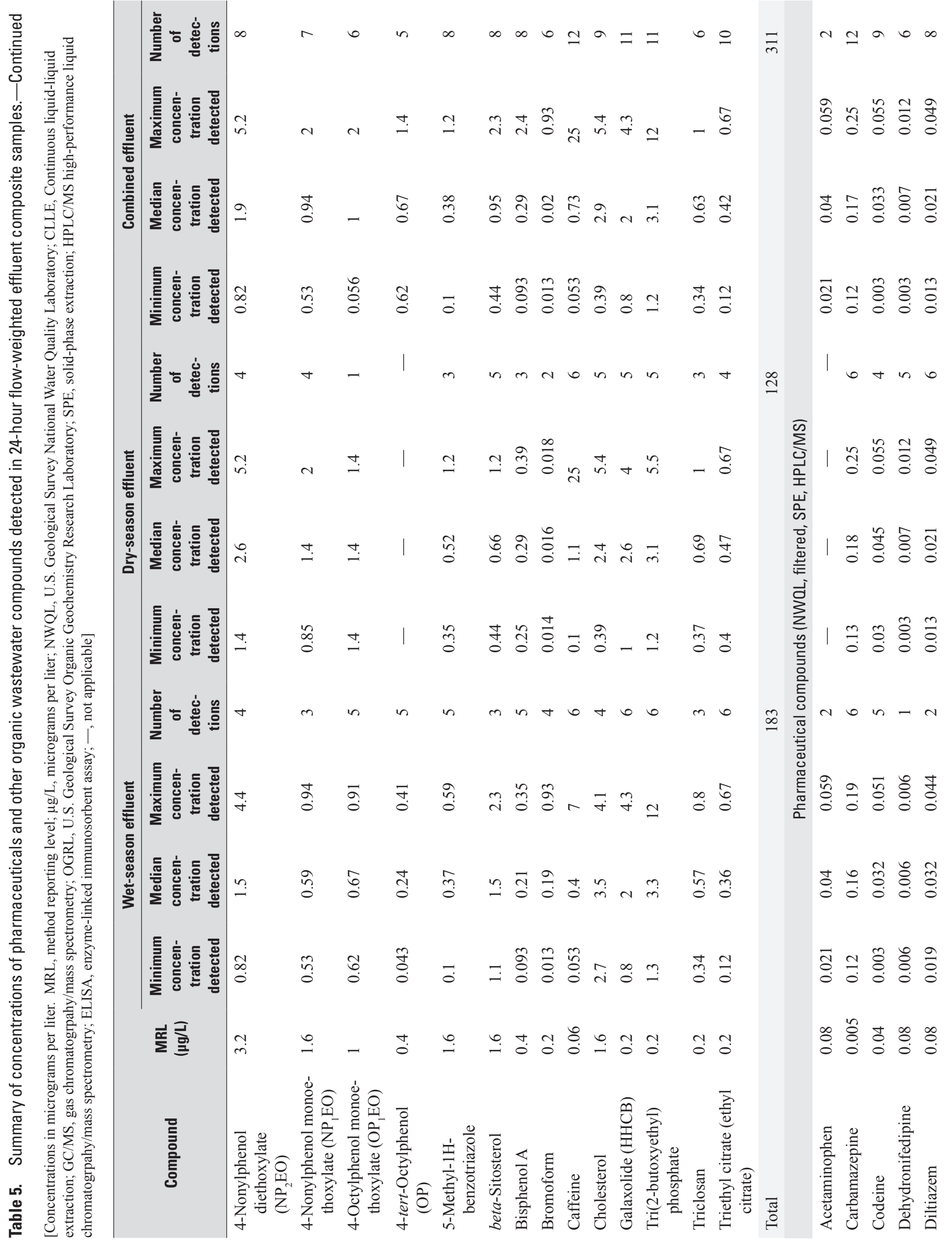




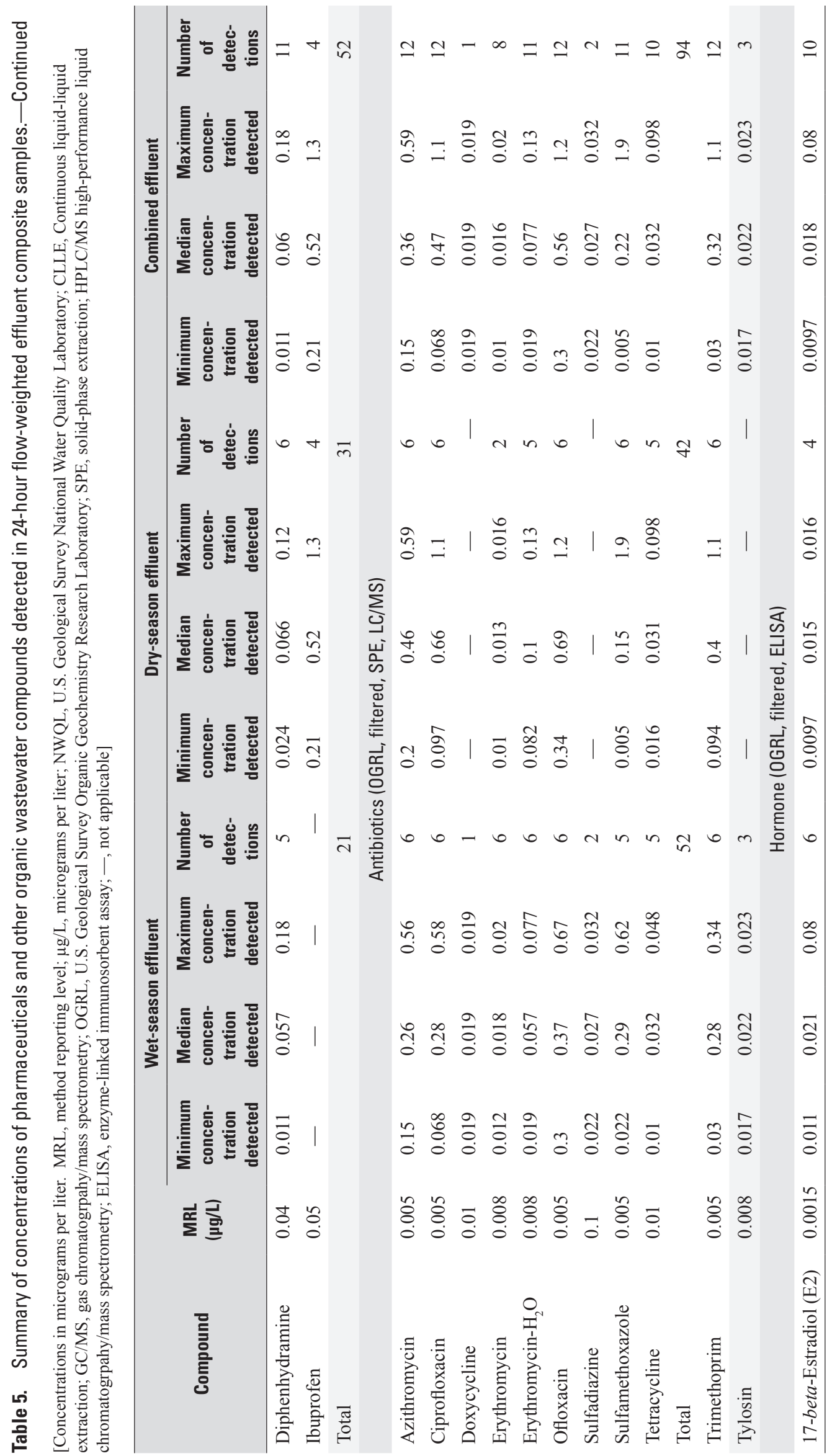



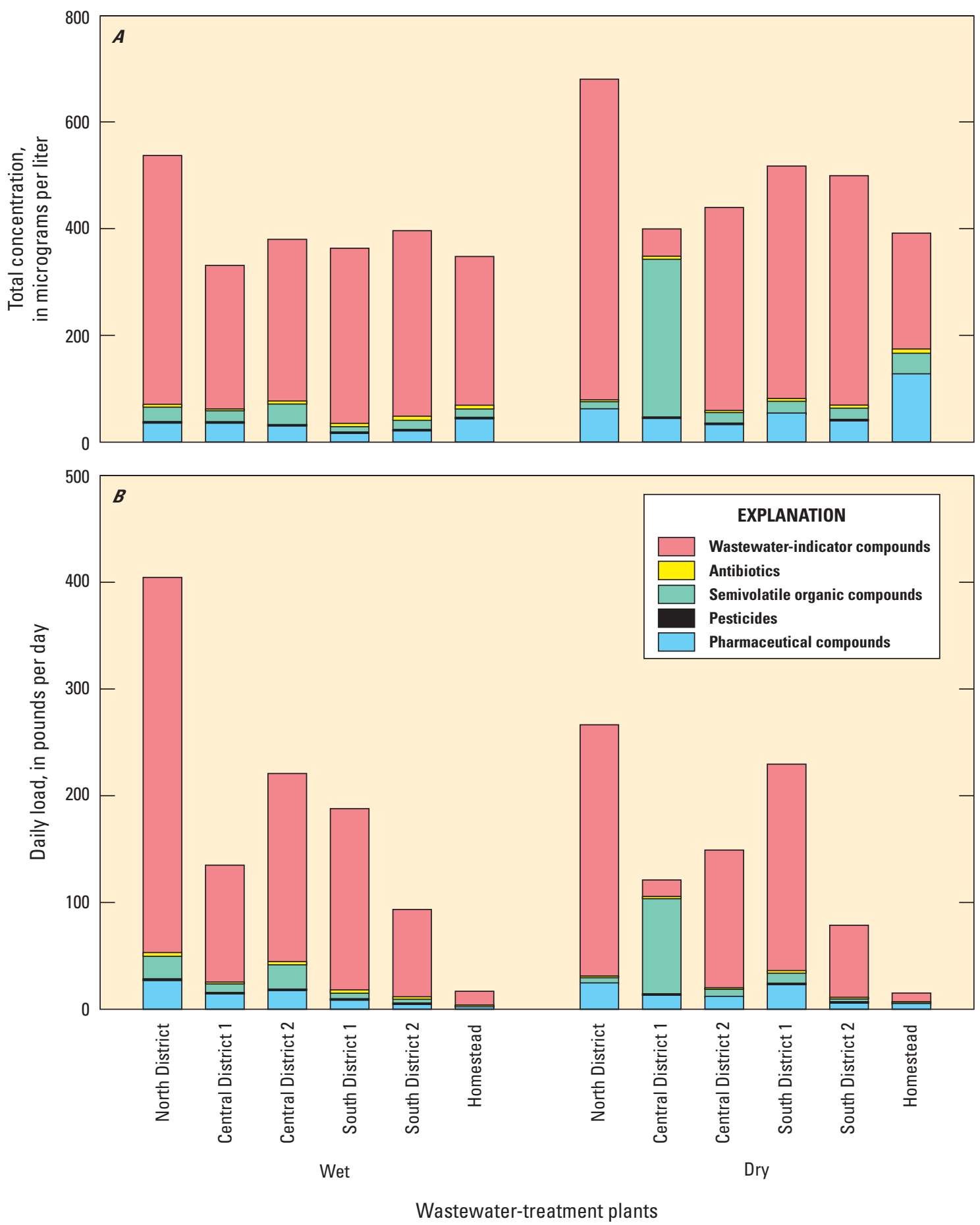

Figure 3. Total concentration $A$, and daily loads $B$, of pharmaceuticals and other organic wastewater compounds in the influent water samples from wastewater-treatment plants in Miami-Dade County, Florida. 
sulfonamide, had the greatest concentration range ( 0.029 to $1.7 \mu \mathrm{g} / \mathrm{L})$ and highest median concentration $(1.1 \mu \mathrm{g} / \mathrm{L})$ while erythromycin- $\mathrm{H}_{2} \mathrm{O}$ showed the smallest concentration range ( 0.009 to $0.22 \mu \mathrm{g} / \mathrm{L})$, and tetracycline had the lowest median concentration $(0.11 \mu \mathrm{g} / \mathrm{L}$; table 4$)$. Erythromycin was only detected in samples collected in the wet season (ranging from 0.008 to $0.01 \mu \mathrm{g} / \mathrm{L}$ ) and sulfathiazole was detected once in the dry season $(0.073 \mu \mathrm{g} / \mathrm{L})$. The 17 antibiotics (enrofloxacin, lomefloxacin, sarafloxacin, roxithromycin, tylosin, virginiamycin, sulfachloropyridazine, sulfadimethoxine, sulfamethazine, chlorotetracyline, oxytetracycline, epi-chlorotetracycline, epi-iso-chlorotetracycline, epi-oxytetracycline, iso-chlorotetracycline, chloramphenicol, and ormetoprim) were not detected in any influent sample collected, although the poor recovery of chloramphenicol ( 0 percent) and virginiamycin $(0$ percent $)$ in the influent spike sample (app. 1) affected the probability for their detection. The hormone $\mathrm{E} 2$ was detected in all but one influent sample (ranging from 0.011 to $0.22 \mu \mathrm{g} / \mathrm{L}$, median of $0.042 \mu \mathrm{g} / \mathrm{L}$ ), and was detected at higher concentrations in the dry season (table 4).

\section{Pharmaceuticals and Other Organic Wastewater Compounds Detected in 24-Hour Flow-Weighted Effluent Composite Samples}

Organic compounds in all classes were detected in effluent samples collected at each plant (table 5). Similar to the influent samples, the total concentrations in effluent samples collected in the dry season were generally 10 to 30 percent higher than samples collected in the wet season, with the exception of SD 1 (fig. 4A; app. 4). Estimated loads ranged from 0.3 to $25.7 \mathrm{lb} / \mathrm{d}$ and were higher in the wet season at four of the six plants (fig. $4 B$; app. 4). Wastewater-indicator compounds accounted for greater than 64 percent of the total concentration in each effluent sample while E2 accounted for less than 0.1 percent of the total concentration (app. 4). For graphical purposes, E2 was not included in figure 4.

Nineteen SVOCs were detected in at least one effluent sample (table 5). The compound 1,4-dichlorobenzene was detected in every 24-hr flow-weighted effluent sample (ranging from 0.12 to $2.3 \mu \mathrm{g} / \mathrm{L}$ ). Concentrations of 1,4-dichlorobenzene in effluent from the WWTPs were well below the U.S. Environmental Protection Agency (USEPA) maximum contaminant level (MCL) of $75 \mu \mathrm{g} / \mathrm{L}$ for drinking water. Trace amounts (ranging from 0.021 to $0.14 \mu \mathrm{g} / \mathrm{L}$ ) of 2,4,6-trichlorophenol were also detected in every effluent sample. The compound 2,4-dimethylphenol was detected in all but one effluent samples (ranging from 0.05 to $0.45 \mu \mathrm{g} / \mathrm{L}$ ). The remaining 16 compounds were detected less frequently at low concentrations (less than or equal to $1 \mu \mathrm{g} / \mathrm{L}$ ).

Thirteen pesticide compounds were detected in at least one effluent sample (table 5). The three pesticide compounds 3,4-dichloroaniline, fipronil, and fipronil sulfide, were detected in every effluent sample. The greatest concentration range
( 0.046 to $0.24 \mu \mathrm{g} / \mathrm{L}$ ) was for 3,4-dichloroaniline, a pesticide degradate, and highest median concentration $(0.1 \mu \mathrm{g} / \mathrm{L})$ while fipronil sulfide had the smallest concentration range $(0.006$ to $0.019 \mu \mathrm{g} / \mathrm{L})$ and lowest median concentration $(0.01 \mu \mathrm{g} / \mathrm{L})$. Similar to the influent samples, carbaryl was detected at the highest concentrations $(0.29 \mu \mathrm{g} / \mathrm{L})$.

Forty-nine wastewater-indicator compounds were detected in at least one effluent sample (table 5). Caffeine showed the greatest concentration range (ranging from 0.053 to $25 \mu \mathrm{g} / \mathrm{L}$ ) and the greatest concentration of all the target compounds in effluent samples. Caffeine is a stimulant in soft drinks, tea, coffee and energy drinks. A derivative of caffeine, 1,7-dimethylxanthine, was also detected as high as $1.3 \mu \mathrm{g} / \mathrm{L}$. Tri(2-butoxyethyl) phosphate, a flame retardant, also showed a large concentration range (1.2 to $12 \mu \mathrm{g} / \mathrm{L})$ and had the highest median concentration $(3.1 \mu \mathrm{g} / \mathrm{L})$.

Among the pharmaceuticals, seven were detected in effluent samples (table 5). Ibuprofen had the greatest concentration range (less than 0.05 to $1.3 \mu \mathrm{g} / \mathrm{L}$ ) and highest maximum concentration. All other compounds were detected at concentrations less than or equal to $0.25 \mu \mathrm{g} / \mathrm{L}$. Carbamazepine was the only pharmaceutical detected in every effluent sample collected $(0.12$ to $0.25 \mu \mathrm{g} / \mathrm{L})$. The high detection of carbamazepine in effluent waters is consistent with previous studies that concluded carbamazepine to be neither subjected to degradation nor to adsorption processes during wastewater treatment (Clara and others, 2004).

Eleven antibiotics were detected in at least one effluent sample (table 5). Trimethoprim, azithromycin, ciprofloxacin, and ofloxacin were detected in every effluent sample collected ( 0.03 to $1.2 \mu \mathrm{g} / \mathrm{L}$ ). Sulfamethoxazole (a sulfonamide) had the greatest concentration range (less than 0.005 to $1.9 \mu \mathrm{g} / \mathrm{L}$ ). Doxycycline, sulfadiazine, and tylosin were only detected in effluent samples collected in the wet season. The hormone E2 was detected in 10 of the 12 effluent samples (ranging in concentration from 0.0097 to $0.08 \mu \mathrm{g} / \mathrm{L}$ ).

\section{Percent Reduction in Concentrations}

One purpose of this report is to assess the percent reduction in concentration of pharmaceuticals and other organic wastewater compounds during treatment at each plant. The percent reduction (PR) is defined as:

$$
\mathrm{PR}=\frac{\left(C_{I}-C_{E}\right)}{C_{I}} \cdot 100
$$

where $C_{\mathrm{I}}$ is the concentration of a compound in the influent, and $C_{\mathrm{E}}$ is the concentration of a compound in the effluent. There are a number of physical, chemical, and biological processes (for example, biodegradation, volatilization, photolysis, and adsorption, and so forth) that occur during wastewater treatment that can contribute to the overall percent reduction, as well as a number of factors (for example, temperature, $\mathrm{pH}$, 

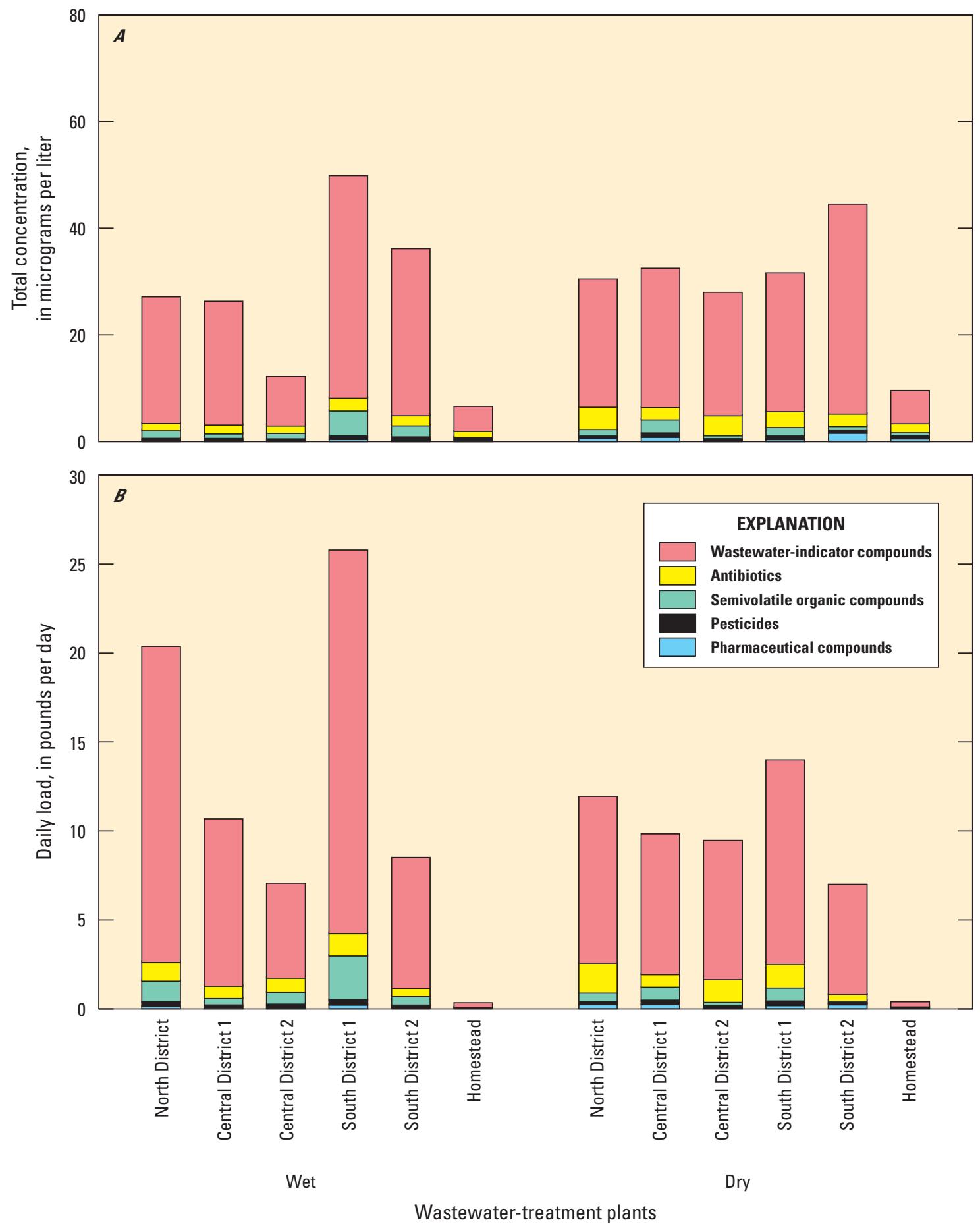

Figure 4. Total concentration $A$, and daily loads $B$, of pharmaceuticals and other organic wastewater compounds in the effluent water samples from wastewater-treatment plants in Miami-Dade County, Florida. 
solids retention time, hydraulic retention time, and biomass concentration) that can affect the rates of these processes. This section summarizes the percent reduction in concentration of pharmaceuticals and other organic wastewater compounds at the effluent at each plant in both the dry and wet seasons.

Table 6 lists PR values of compounds at the effluents of the six plants in both the dry and wet seasons. Many of the PR values were estimated because the influent and(or) effluent concentration was reported as an estimated concentration reported as "E" by the laboratory. A positive PR indicates a decrease in concentration during treatment while a negative PR indicates an increase in concentration during treatment. Several circumstances could lead to a negative PR, including: (1) large variations in chemical inputs that the influent sampling design was not able to capture; (2) minor absolute sampling/analytical errors at low concentrations that produced relatively strongly negative PR values for recalcitrant compounds; (3) a compound was formed, either as a byproduct or from the degradation of a larger compound, during treatment processes; and (4) changes in solubility conditions during the treatment processes (for filtered samples). There were also numerous instances where a compound was detected in the effluent sample and not in the associated influent sample. The percent reduction in these instances could not be computed due to censored influent data and was reported as "C."

\section{Semivolatile Organic Compounds}

There were 20 SVOCs for which PR values could be determined (table 6). The median PR values for individual compounds ranged from 24.8 to 100 percent. Furthermore, 15 (75 percent) compounds had median PR values of 90 percent or greater indicating SVOCs are well removed. The PR values could not be computed for seven SVOCs (1,2,4-trichlorobenzene, 1,3-dichlorobenzene, 2-chloronaphthalene, 2-nitrophenol, dimethyl phthalate, nitrobenzene, and n-nitrosodimethylamine (NDMA)), because they were only detected in effluent samples. The detection of these seven compounds in effluent samples, along with nondetection in the complementary influent sample, could be an indication that these compounds are byproducts of the treatment processes or are degradation products of larger compounds. For example, studies have shown that NDMA is formed when wastewater is disinfected with chlorine, especially when ammonia is present (Pehlivanoglu-Mantas and others, 2006). NDMA was only present in the effluent at the three plants (CD1, CD2, and ND) that use chlorination to disinfect the treated wastewater.

\section{Pesticides and Pesticide Degradates}

There were 12 pesticides and pesticide degradates for which PR values could be determined (table 6). Percent reduction values were highly variable for pesticides and pesticide degradates with median values for individual compounds ranging from -16.1 to 100 percent. Percent reduction values could not be calculated for one pesticide, metribuzin, and one pesticide degradate, 2-chloro-4-isopropylamino-6-amino-s-triazine (CIAT), because they were only detected in effluent samples.

\section{Wastewater-Indic ator Compounds}

Percent reduction values were determined for 52 wastewater-indicator compounds (table 6) with median values for individual compounds ranging from -32.3 to 100 percent. Generally, wastewater-indicator compounds were removed with 36 (about 70 percent) compounds having median PR values of 90 percent or greater. Negative PR values for 11 compounds, including the 4 organophosphate flame retardant compounds (tri(2-butoxyethyl) phosphate (TBEP), tri(2-chloroethyl) phosphate (TCEP), tri(dichloroisopropyl) phosphate (TDCP), and tributyl phosphate (TBP), were noted on at least one occasion. The median PR value for the four organophosphate flame retardant compounds TBEP, TCEP, TDCP, and TBP were $55.9,-32.4,-24.9$, and 14.7, respectively. The lower PR values of the two chlorinated organophosphates (TCEP and TDCP) compared with the non-chlorinated derivatives (TBEP and TBP) is consistent with reported trends in removal for these compounds during wastewater treatment in Germany (Meyer and Bester, 2004).

Percent reduction values could not be calculated for two wastewater-indicator compounds (3,4-dichlorophenyl isocyanate and anthraquinone) because they were only detected in effluent samples. However, the nondetection of 3,4-dichlorophenyl isocyanate in the influent spike sample (app. 1) indicates that there was a problem detecting this compound in influent samples. The presence of anthraquinone in effluent may be from the oxidation of anthracene in the aeration process.

\section{Pharmaceuticals}

There were five pharmaceuticals for which PR values could be determined at least once (table 6) with median values for individual compounds ranging from -24.5 to 100 percent. Percent reduction values were highly variable for pharmaceuticals. For example, acetaminophen (99.8 to 100 percent) was effectively removed during treatment at each plant while carbamazepine (-321 to 19.9 percent) and codeine $(-1,120$ to -66.0 percent $)$ had very low and highly variable removal rates. Percent reduction values could not be calculated for three pharmaceuticals (dehydronifedipine, diltiazem, and diphenhydramine) because they were only detected in effluent samples. There were also four occasions when PR values could not be calculated for codeine. In a similar treatment study using the same analytical method, Lietz and Meyer (2006) reported higher concentrations of codeine, diltiazem, and diphenhydramine in effluent samples compared 


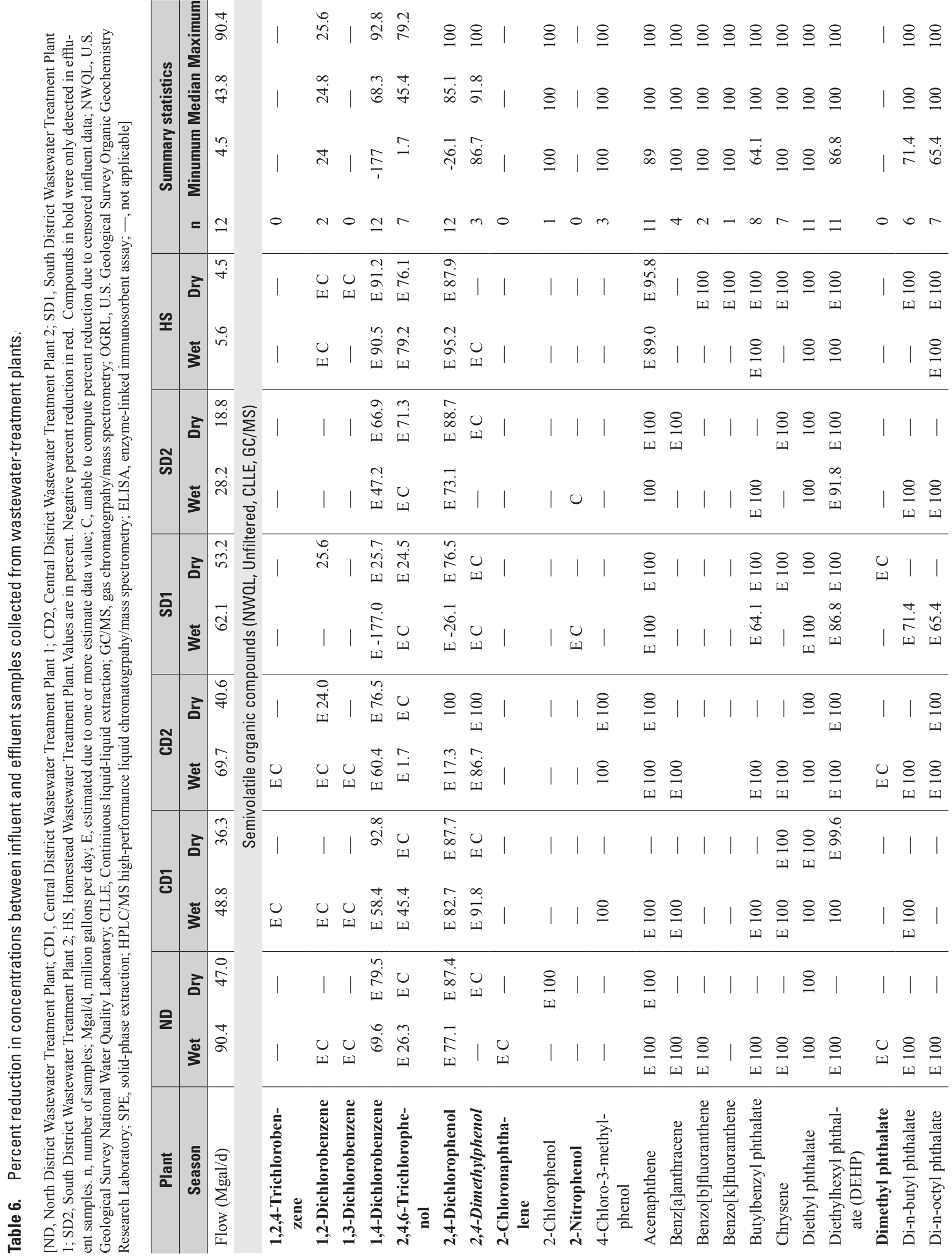




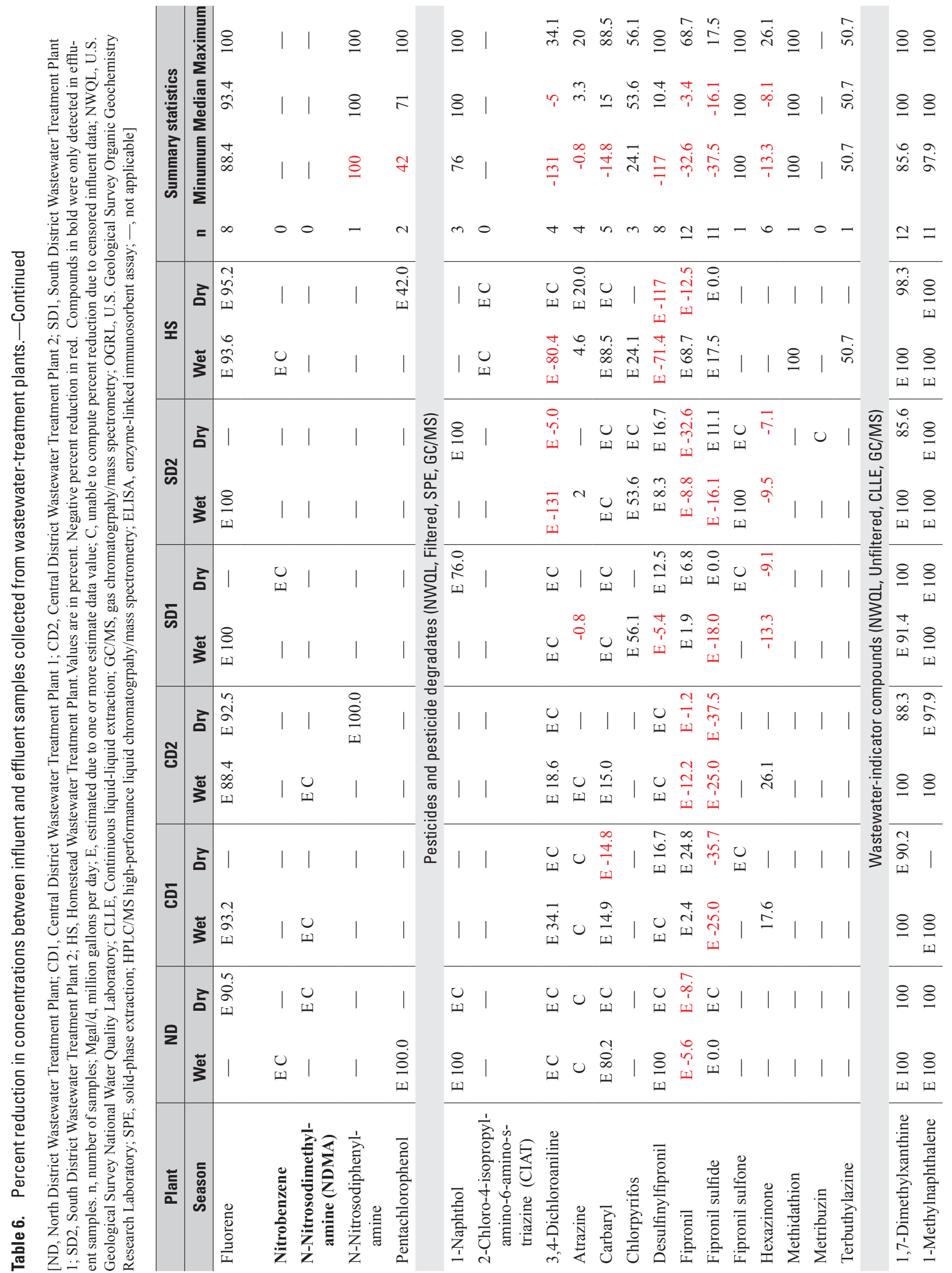




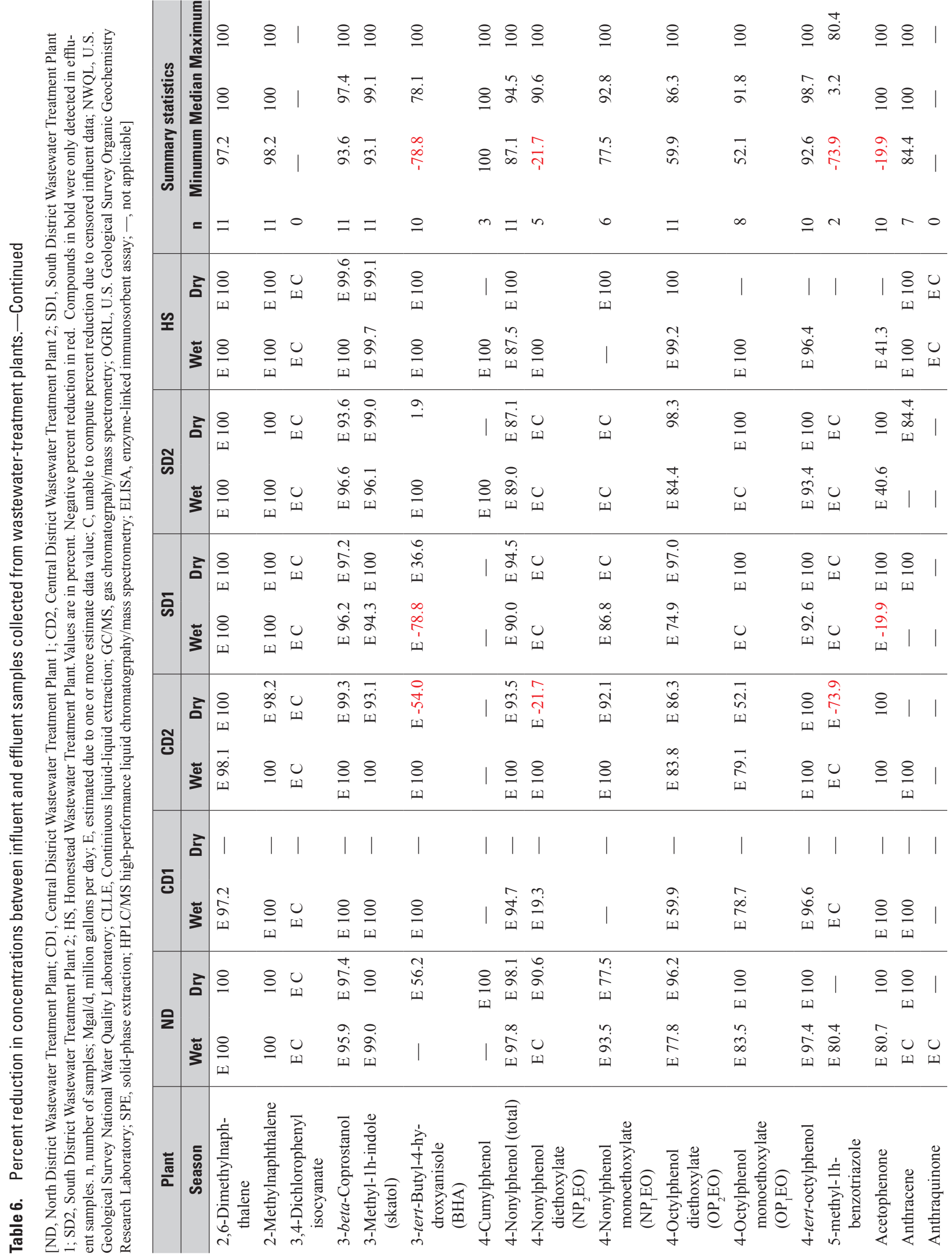




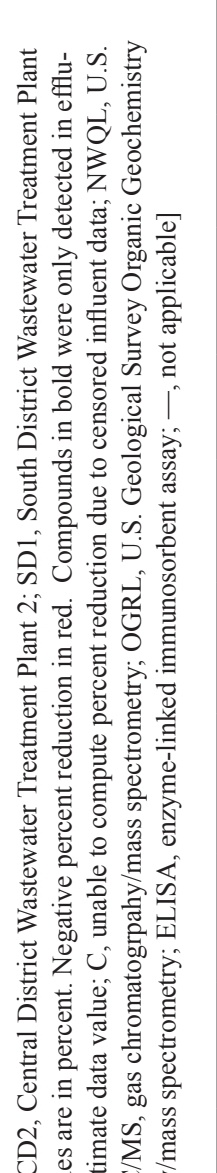

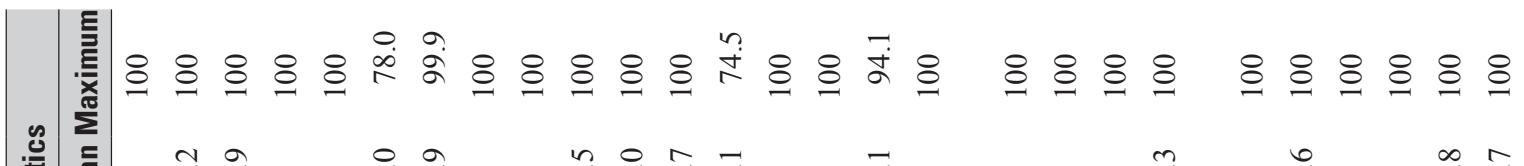
产

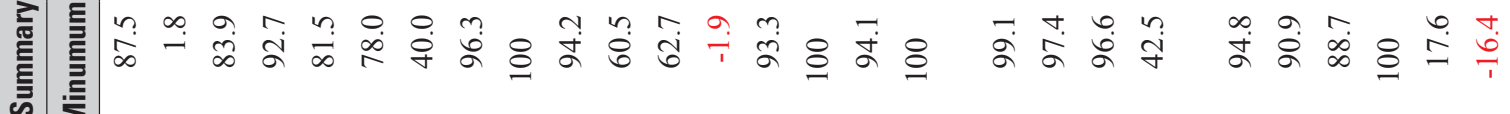
के

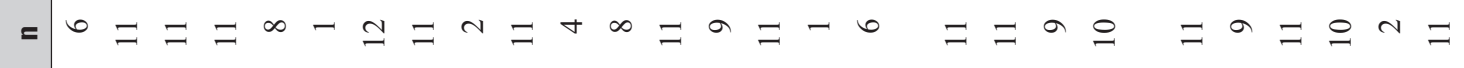

Z|

또

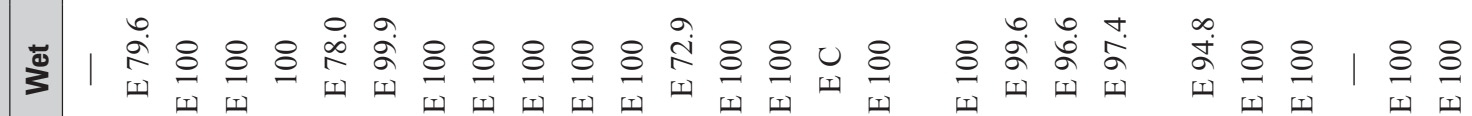

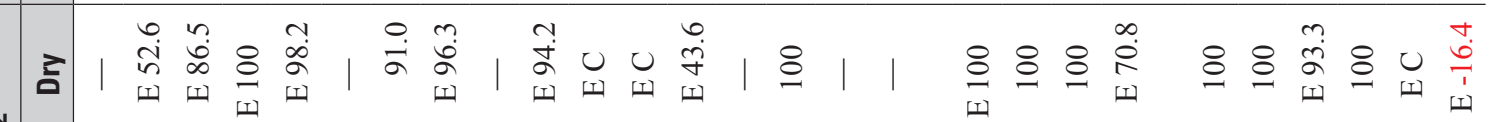

ณิ

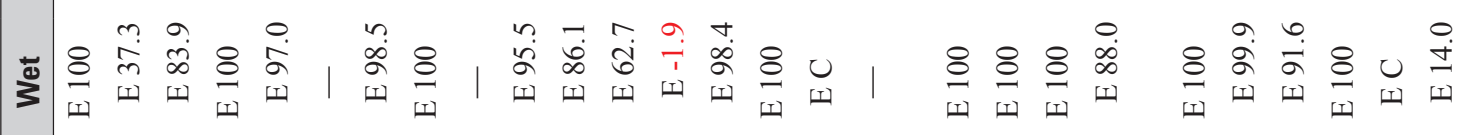

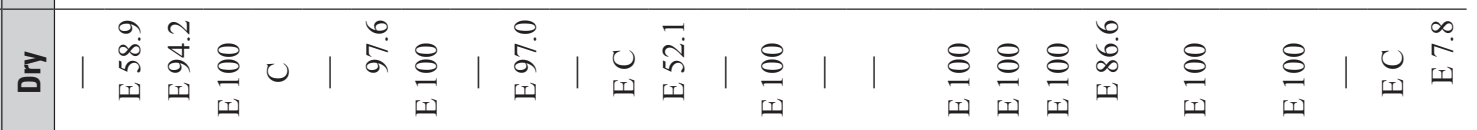

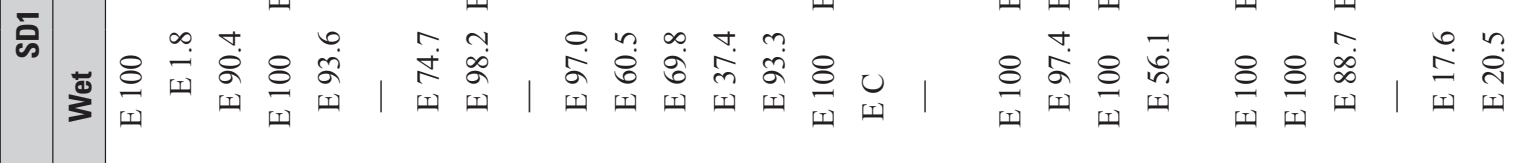

0

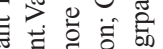

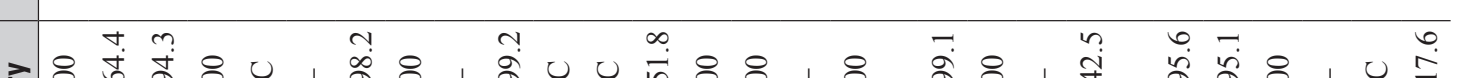

ปै)

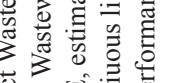

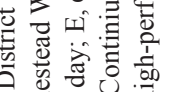

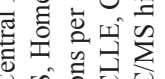

ธิن

ㄴ.

$\underset{\substack{++}}{\text { II }}$

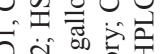

壳. 总

ङ

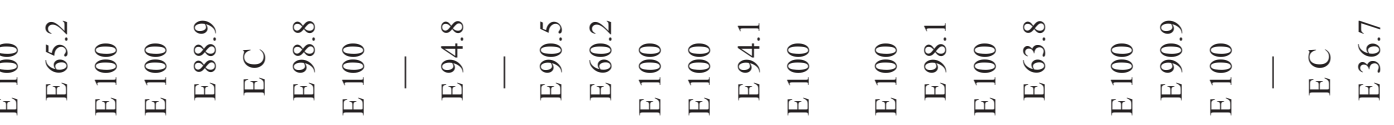

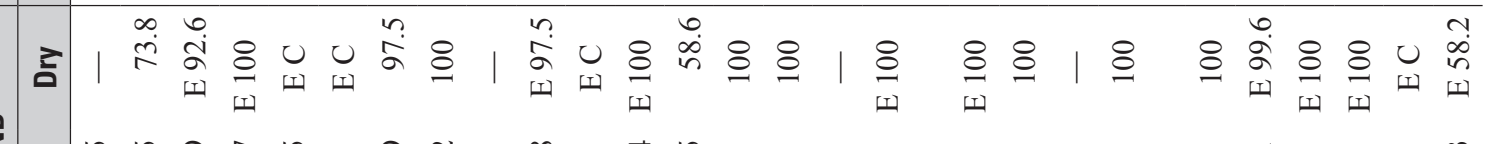

을

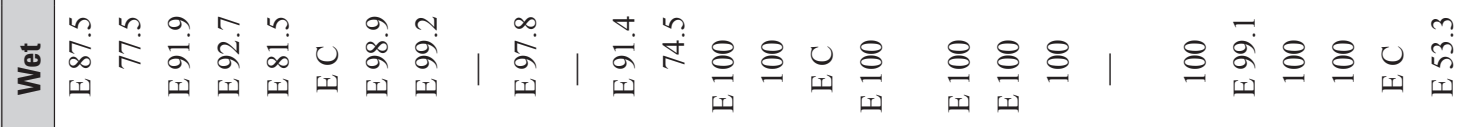

की

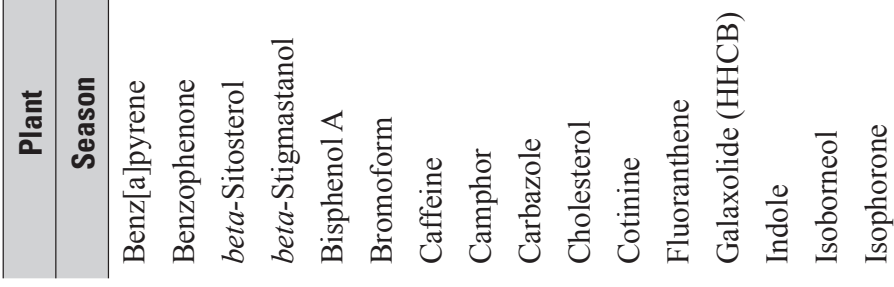
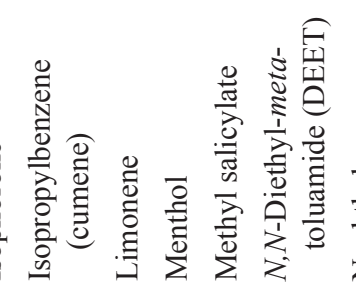

$\frac{0}{2}$
$\frac{0}{0}$
$\frac{0}{0}$
$\frac{0}{0}$
$\frac{\pi}{0}$
$\oplus$ 


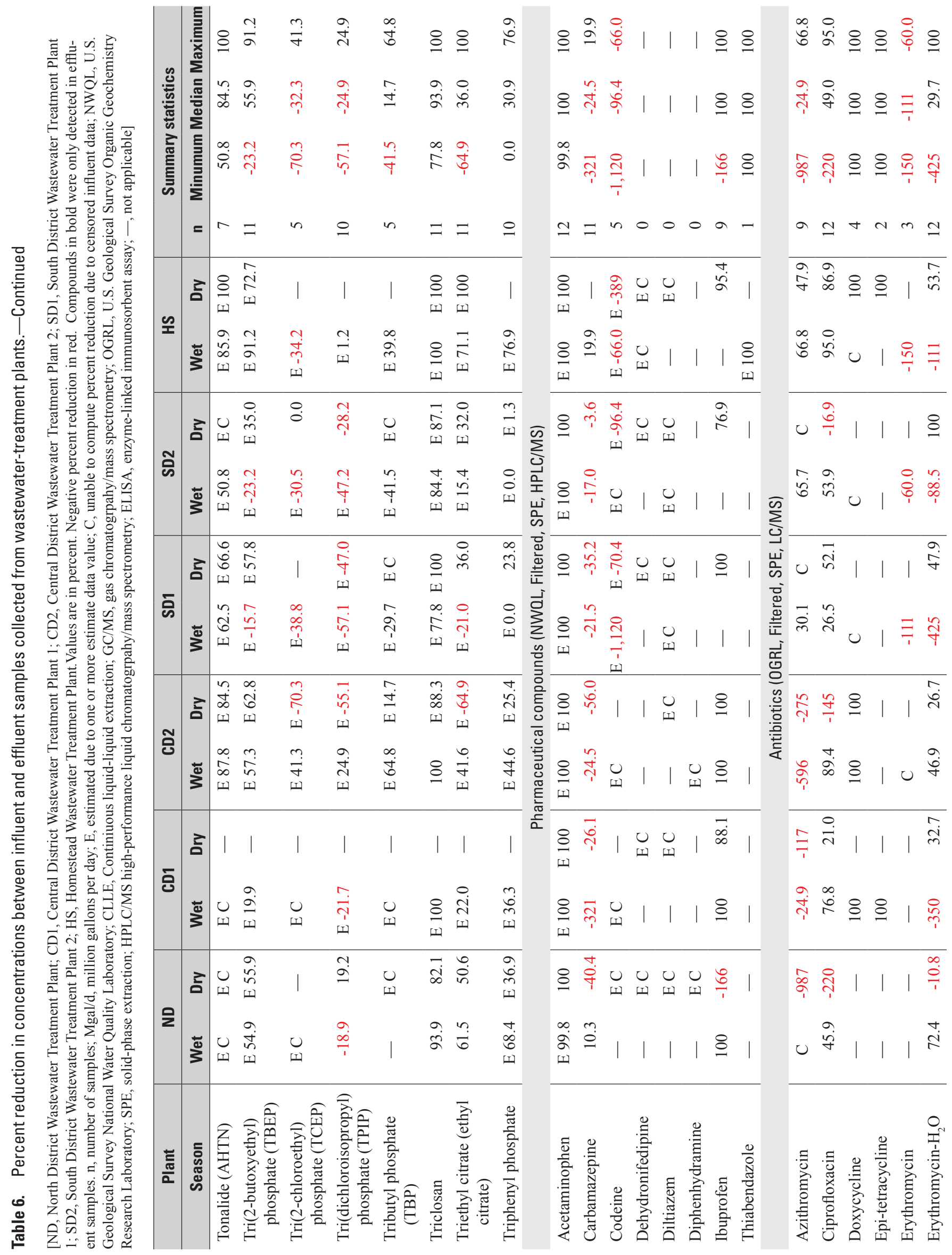




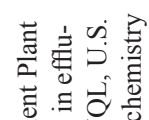

帚总方品

跣氙

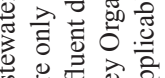

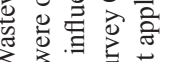

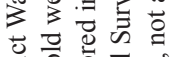

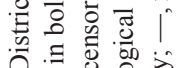

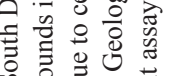

क o.

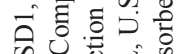

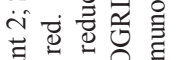

党.

言.

吾语

可

政

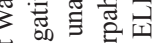

范论

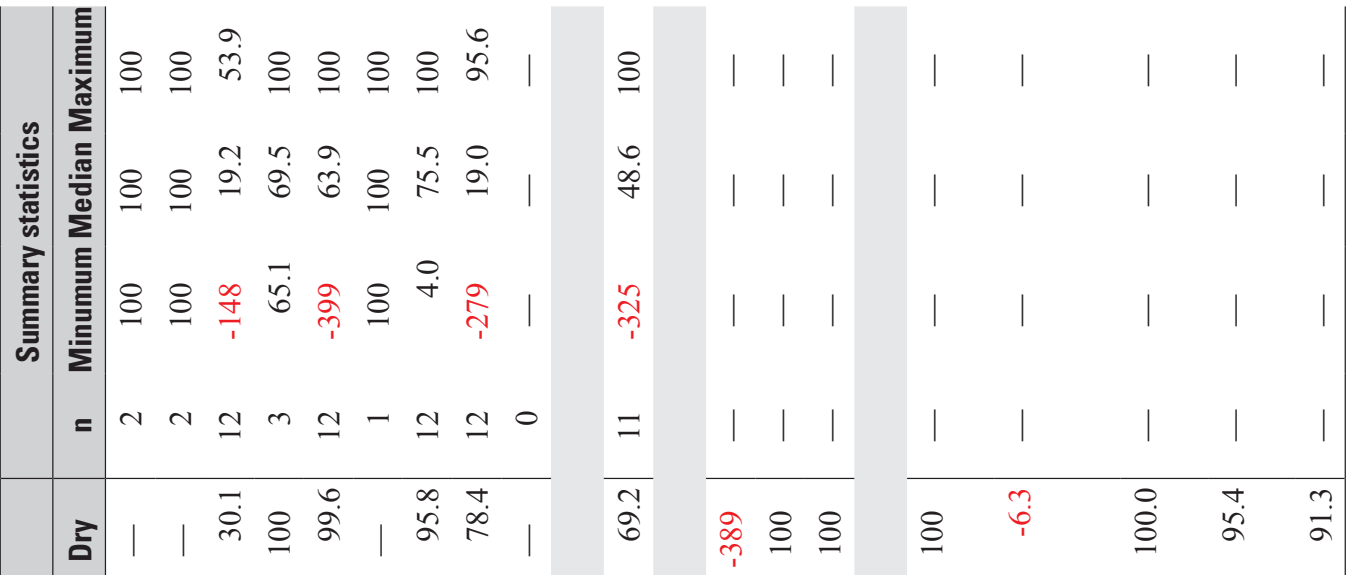

또

sँ

के

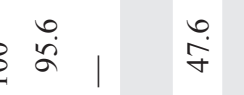

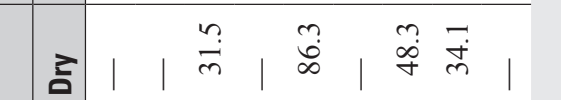

คิ

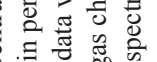

กิ่

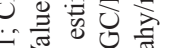

咅范言

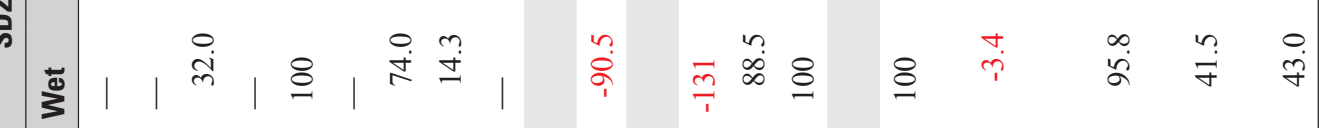

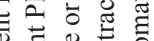

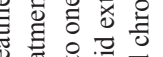

要焉

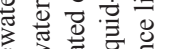

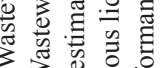

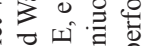

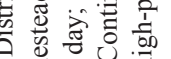

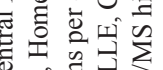

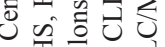

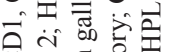

喜语语

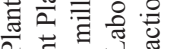

远

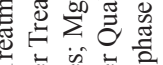

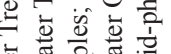

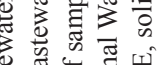

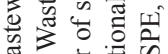

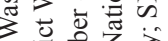

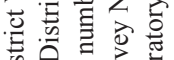

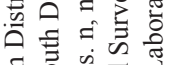

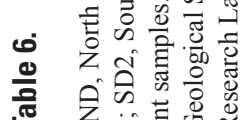

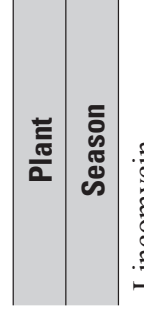

ㄴ.

蛋

क्ष

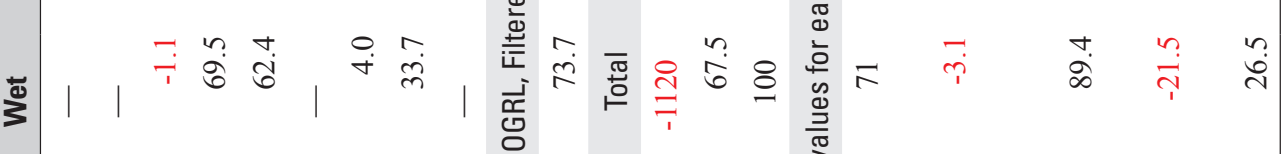

ชิ

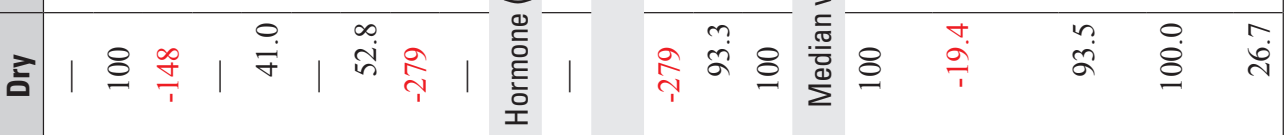

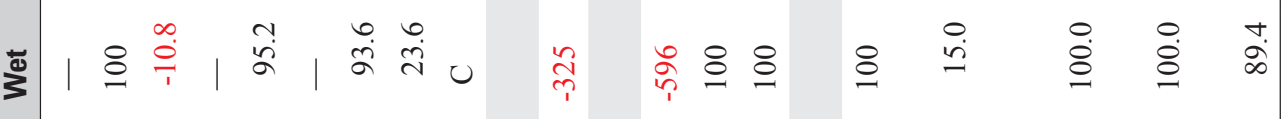

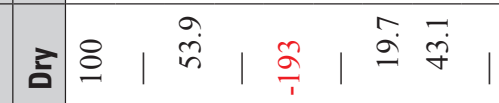

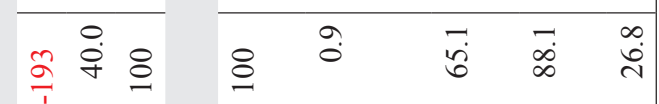

ธิ

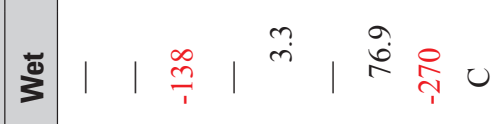

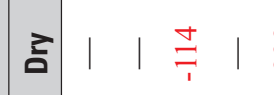

일

sั

, ${ }^{\infty}$,

$1 \stackrel{8}{8}$

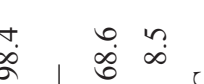

ֻீ.

我

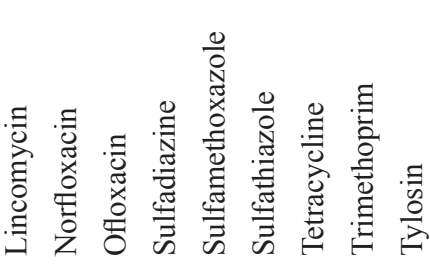

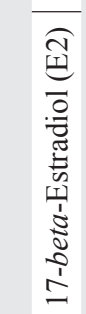

重重衰

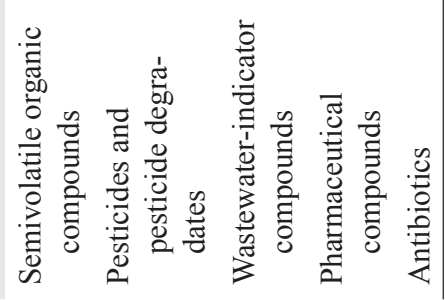


to influent samples, and attributed the higher concentrations in effluent samples to solubility changes caused by matrix conditions and (or) issues with matrix interferences using the LC/MS method. Percent reduction values for ibuprofen were high (greater than 76.9 percent) during treatment for all but one sample occasion (NDWWTP, dry season).

\section{Antibiotics}

There were 14 antibiotics for which PR values could be determined at least once (table 6), with median values for individual compounds ranging from -111.1 to 100 percent. Similar to the pharmaceuticals, PR values were highly variable for antibiotics. For example, PR values for doxycycline were 100 percent on four occasions, but could not be calculated on three occasions due to nondetects in influent samples. Percent reduction values for sulfamethoxazole and erythromycin- $\mathrm{H}_{2} \mathrm{O}$ were highly variable, ranging from -399 to 100 percent and -425 to 100 percent, respectively. Percent reduction values for four antibiotics (epi-tetracycline, lincomycin, norfloxacin, and sulfathiazole) were 100 percent when these compounds were detected in influent samples. Percent reduction values could not be calculated for one antibiotic (tylosin) because it was only detected in effluent samples.

\section{7-beta-estradiol}

Percent reduction values for 17-beta-estradiol (E2) were highly variable (ranging from -325 to 100 percent; table 6). This large variation in PR values is not consistent with other studies, which determined that E2 was effectively removed (greater than 98 percent) during treatment at activated sludge plants in Germany (Andersen and others, 2003). The reason for the large variation at the plants for this study is unknown and will require further investigation.

\section{Pharmaceuticals and Other Organic Wastewater Compounds Detected in Groundwater, Canal Water, and Canal Bed Sediments}

The HSWWTP has discharged treated effluent since the 1950 s, initially to onsite percolation ponds, and more recently directly to the groundwater table using onsite rapid-rate soakage trenches. This section of the report summarizes the occurrence of pharmaceuticals and other organic wastewater compounds in groundwater, canal water, and bed sediments near the HSWWTP. The occurrence and concentrations of pharmaceuticals and other organic wastewater compounds in the dry season versus the wet season are compared.

\section{Pharmaceuticals and Other Organic Wastewater Compounds in Groundwater near Effluent Soakage Trenches}

Groundwater samples were collected from three monitoring wells (MW-1, MW-2, and MW-3; fig. 2) at variable distances from the soakage trenches to determine whether pharmaceuticals and other organic wastewater compounds that are not removed during treatment are being transported in the Biscayne aquifer. Samples were collected on two occasions, August 11, 2008 (wet season) and February 10-11, 2009 (dry season), and analyzed for the pharmaceuticals and other organic wastewater compounds listed in table 2 .

In both the wet and dry seasons, groundwater from the three monitoring wells was suboxic with dissolved-oxygen (DO) concentrations ranging from 0.18 to $0.56 \mathrm{mg} / \mathrm{L}$. Dissolved-oxygen concentrations in groundwater samples at this site exceeded the median DO concentration $(0.14 \mathrm{mg} / \mathrm{L})$ from 65 monitoring wells that tap the Biscayne aquifer (Lindsey and others, 2009).

Measureable concentrations of 41 compounds (including 6 SVOCs, 11 pesticides and pesticide degradates, 17 wastewater-indicator compounds, 3 pharmaceuticals, and 4 antibiotics) were detected in one or more groundwater samples (table 7; fig. 5). Fourteen compounds were detected in every groundwater sample collected (compounds shown in bold type, table 7). Generally, concentrations were below $0.5 \mu \mathrm{g} / \mathrm{L}$ with the exception of the fragrance HHCB (E $0.62-1.31 \mu \mathrm{g} / \mathrm{L})$, the antibiotic sulfamethoxazole $(0.14-0.57 \mu \mathrm{g} / \mathrm{L})$, and the flame retardant tri(2-butoxyethyl)phosphate (E $0.51 \mu \mathrm{g} / \mathrm{L}$ ) (table 7; fig. 5 . The USEPA MCLs exist for a small set of these compounds, but none of the detected compounds exceeded MCLs for drinking water.

Generally, compounds detected in monitoring wells were detected at concentrations similar to or less than concentrations detected in the effluent at the HSWWTP (table 7; fig. 5); however, nine compounds (5-methyl-1h-benzotriazole, desulfinylfipronil amide, fipronil sulfone, hexachlorocyclopentadiene, metolachlor, prometon, simazine, sulfamethazine, and triclosan) were detected in groundwater samples that were not detected in corresponding effluent composite samples. This finding indicates that the source of these compounds is not the HSWWTP and(or) temporal variability in the removal efficiencies for these compounds during treatment at the HSWWTP. For example, 5-methyl-1H-benzotriazole and triclosan were frequently detected in effluent samples at the other plants as part of this study. Therefore, absence in effluent samples at the HSWWTP could mean that these compounds were not present at detectable levels during sample collection. The herbicides metolachlor, prometon, and simazine were not detected in any effluent composite sample for this study and their detection in groundwater at the HSWWTP site could be from the land application of these herbicides in nearby urban and agricultural areas. Several studies have reported the detection of metolachlor, prometon, and simazine in monitoring wells 


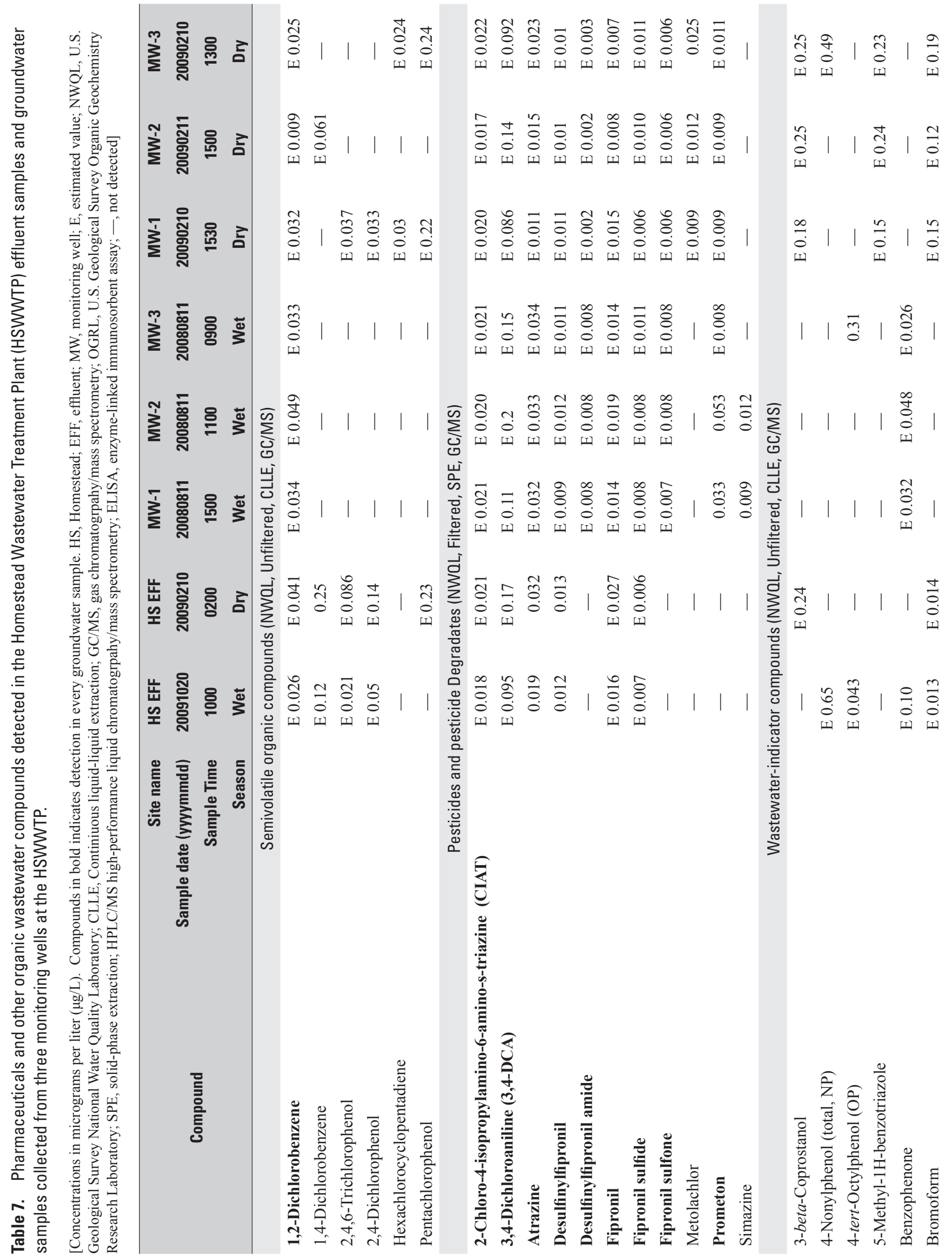




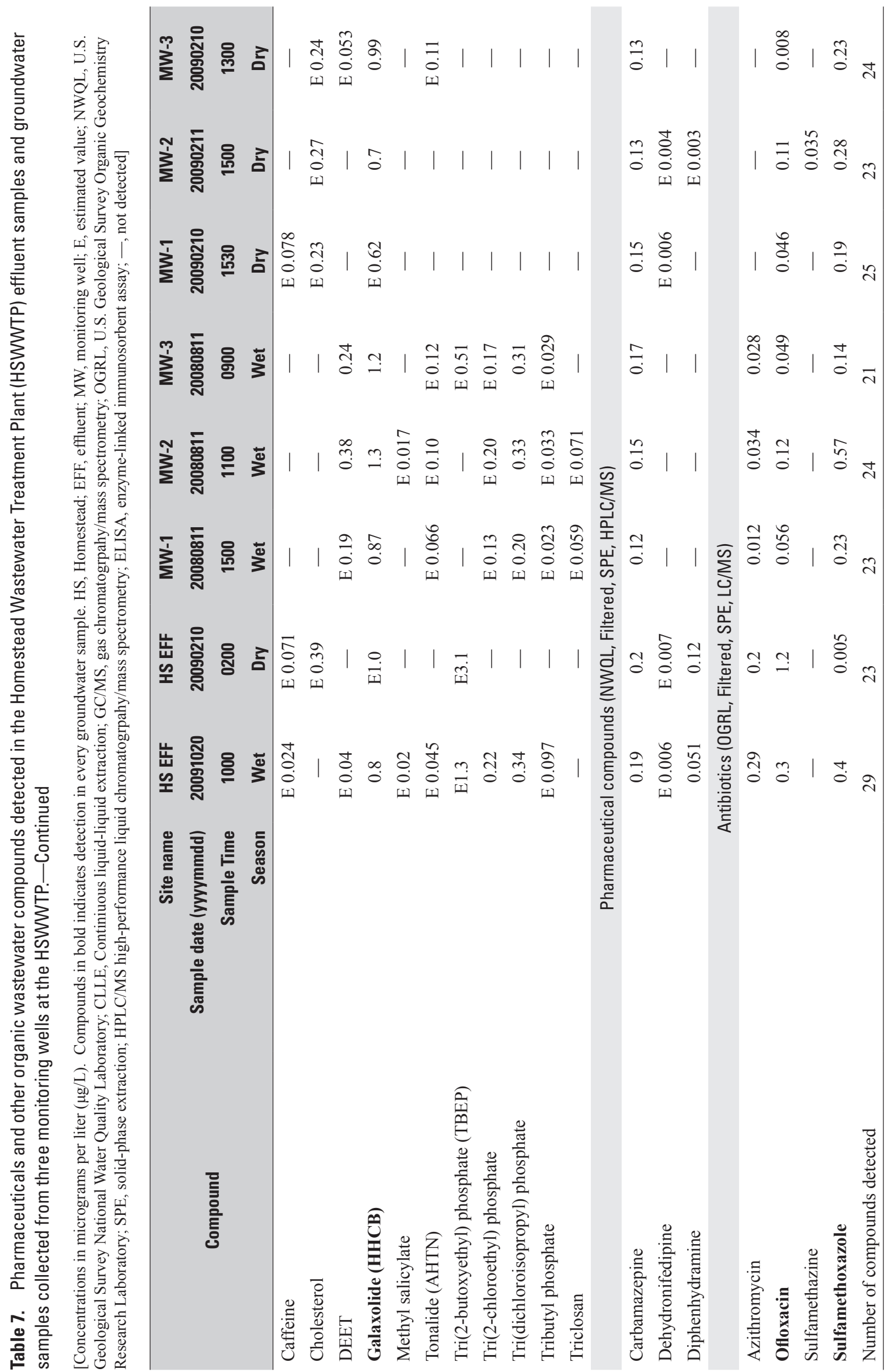




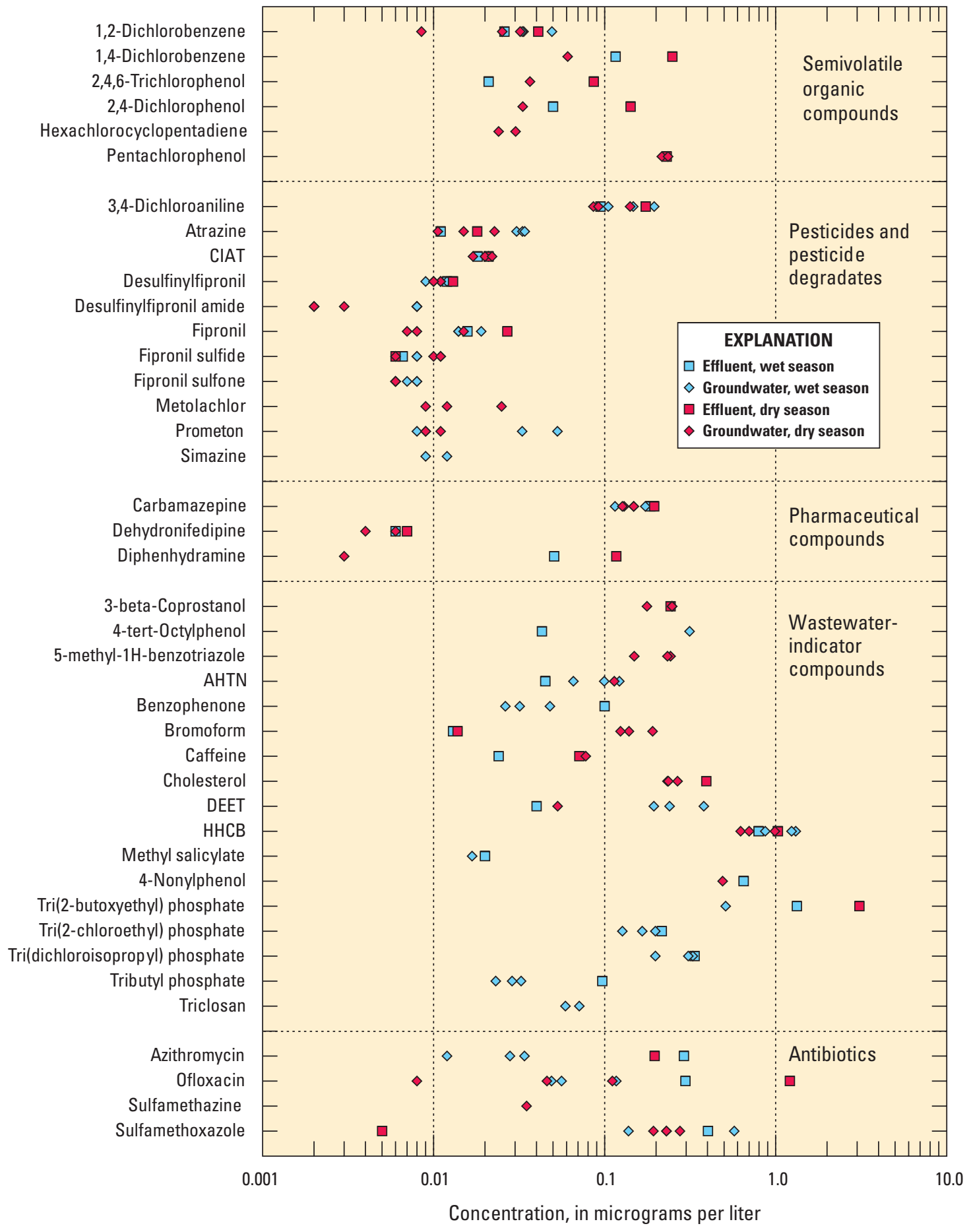

Figure 5. Concentrations of pharmaceuticals and other organic wastewater compounds detected in the Homestead Wastewater Treatment Plant (HSWWTP) effluent and groundwater samples collected from three monitoring wells at the HSWWTP in Florida. 


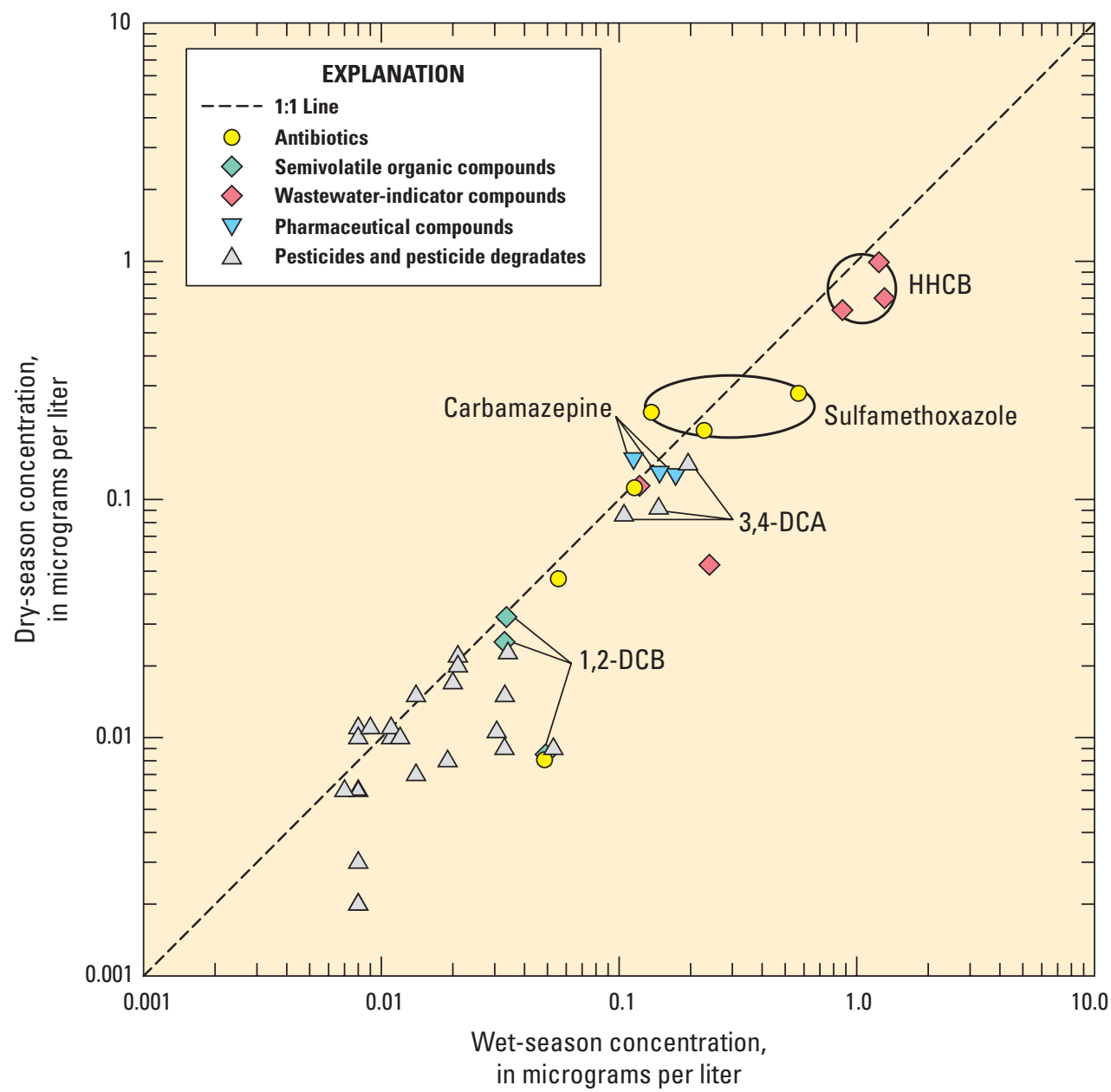

Figure 6. Comparison of pharmaceuticals and other organic wastewater compounds in groundwater samples collected in both the wet season and dry season from three monitoring wells at the Homestead Wastewater Treatment Plant in Florida.

in the Biscayne aquifer (Lindsey and others, 2009) and in public-supply wells near the HSWWTP (Bradner and others, 2005; Foster and Katz, 2010). The presence of fipronil sulfone and desulfinylfipronil amide in groundwater samples could be a result of the oxidation of fipronil and desulfinylfipronil, respectively, after being introduced to the subsurface (Ngim and Crosby, 2001). Both fipronil (E 0.016 and E $0.027 \mu \mathrm{g} / \mathrm{L}$ ) and desulfinylfipronil $(0.012$ and $0.013 \mu \mathrm{g} / \mathrm{L})$ were detected in effluent composite samples from the HSWWTP. Sulfamethazine is a sulfonamide antimicrobial approved strictly for use in veterinary medicine and has been detected in groundwater near known sources of animal waste (Batt and others, 2006). The detection of sulfamethazine in groundwater from well MW-2 in the dry season could be from an animal waste source (for example, application of animal manure to agricultural fields) near the treatment plant.
More compounds were detected in groundwater samples in the dry season (31 compounds were detected in at least one monitoring well, 15 of which were detected only in the dry season) than in the wet season (26 compounds were detected in at least one monitoring well, 10 of which were detected only in the wet season). When it was possible to compare concentrations of a compound in both the wet season and dry season in a monitoring well, concentrations were generally higher in the wet season (table 7; fig. 6). The higher concentrations in groundwater could be a result of larger effluent loads (pounds per day) during wetter months, which could result in an increased total mass discharge to the Biscayne aquifer with corresponding decreased relative dilution from the native groundwater. However, the cause of this difference is uncertain as the lack of multiple samples in both the wet and dry seasons prevented the opportunity to perform a comparison. 
Among the various groups of compounds, the most diagnostic of effluent in the groundwater at this site were HHCB, sulfamethoxazole, 3,4-DCA, 1,2-DCB, and carbamazepine (fig. 6). These compounds were selected because: (1) they were detected frequently in groundwater at this site (table 7) and not detected in groundwater from the Biscayne aquifer in other areas within Miami-Dade County (Foster and Katz, 2010); (2) the data show a tight clustering between effluent and groundwater concentrations (with the exception of sulfamethoxazole) (fig. 5); and (3) they were detected in both the effluent and groundwater samples at concentrations substantially above the MRL (with the exception of 1,2-DCB).

\section{Pharmaceuticals and Other Organic Wastewater Compounds in Canal Water and Bed Sediment}

Canal water and bed sediments in the Mowry Canal (MC) near and at a distance from the HSWWTP were sampled to assess the possibility that pharmaceuticals and other organic wastewater compounds are transported through the groundwater system and discharged at canals (fig. 1). Sampling site MC-1 is located directly adjacent to the HSWWTP, whereas site MC-2 is approximately $1 \mathrm{mi}$ "downstream" of MC-1 (fig. 2). The MC-1 site is assumed to be directly affected by the HSWWTP effluent because of the site's close proximity to the plant (fig. 2). There are no known point sources of wastewater to the Snapper Creek Canal (SC) near SC-1. Canal water samples and bed sediments were collected from site $\mathrm{SC}-1$ on one occasion on July 9, 2008, and from sites MC-1 and MC-2 on two occasions on August 12, 2008 (wet season), and December 9, 2009 (dry season). The occurrence and concentrations of selected organic compounds in canal water and sediments from the Mowry and Snapper Creek Canals were compared during this study. The occurrence and concentrations of selected organic compounds in the dry season versus the wet season in canal water and bed sediments from MC-1 and MC-2 are described herein.

\section{Canal Water}

Samples were analyzed for the pharmaceuticals and other organic wastewater compounds listed in table 2. A total of 51 compounds (including 28 wastewater-indicator compounds, 7 SVOCs, 12 pesticides and pesticide degradates, 2 pharmaceuticals, 1 antibiotic, and the hormone E2) were detected in one or more canal samples (table 8). Generally, concentrations were below $1.0 \mu \mathrm{g} / \mathrm{L}$ with the exception of DEHP from waters at MC-1 (dry season, E $11 \mu \mathrm{g} / \mathrm{L}$ ).

In the Mowry Canal, more compounds were detected in canal water samples collected in the dry season (MC-1, 37 ; MC-2, 25) than in the wet season (MC-1, 11; MC-2, 8) (table 8), which could indicate that increased groundwater discharge and overland flow during precipitation events increases dilution during the wet season. Furthermore, when it was possible to compare concentrations of a compound in both the wet and dry seasons at a particular site, concentrations were generally higher in the dry season (fig. 7). Some compounds were detected at concentrations several orders of magnitude higher in the dry season than in the wet season. Only one compound (cholesterol, MC-2) was detected at a higher concentration in the wet season.

The high concentration of DEHP, a widely used plasticizer and inert ingredient in pesticide products, detected in a water sample collected from MC-1 (dry season) is most likely from surface runoff from nearby roads and(or) the application of pesticides to the nearby canal banks, and not from the HSWWTP. Clara and others (2010) detected DEHP as high as $24 \mu \mathrm{g} / \mathrm{L}$ in surface runoff from roads. Furthermore, because DEHP is effectively removed by (most) wastewater-treatment methods (greater than 78 percent, Dargnat and others, 2009; greater than 95 percent, Clara and others; 2010) and it was not detected in the HSWWTP effluent on either sampling occasion, it is unlikely that the source of DEHP to the canal was the HSWWTP.

Water samples collected from SC-1, the site that has no known point source of wastewater, contained low levels (less than E 0.76 ) of 11 organic compounds, including 5 wastewater-indicator compounds and the non-prescription pharmaceutical acetaminophen (table 8). The detection of these compounds could be an indication that there is a nonpoint source of wastewater to this canal, such as leaky sewer lines, effluent from septic tanks in the area, and(or) surface runoff from nearby roads.

\section{Bed Sediment}

Many wastewater-indicator compounds have moderate to large log octanol-water partitioning coefficients and will undergo hydrophobic partitioning into organic-rich bed sediments once released into the environment. Bed sediments were analyzed for the 57 wastewater-indicator compounds listed in table 3 and are the same wastewater-indicator compounds analyzed in water samples. Previous studies have used the presence of these compounds in bed sediments as a diagnostic tool for assessing the discharge of wastewater into surface-water bodies (Burkhardt and others, 2006; Moon and others, 2008).

Bed sediments from all three sites included in this study contained a variety of wastewater-indicator compounds (fig. 8; table 9). For ease of comparison and discussion, the wastewater-indicator compounds included in this section have been grouped into three general categories: (1) personal care products (PCPs), (2) biogenic sterols, and (3) others (for example, PAHs and alkyl-PAHs, wood preservative, industrial solvent,and so forth). The compounds that comprise each of these groups are listed in table 3.

The sediments from the two Mowry Canal sites had the same number (17) of detections of wastewater-indicator compounds, 15 of which were detected at both sites (table 9). More compounds were detected in sediments at MC-1 (15), the site directly next to the HSWWTP, than at MC-2 (12), 


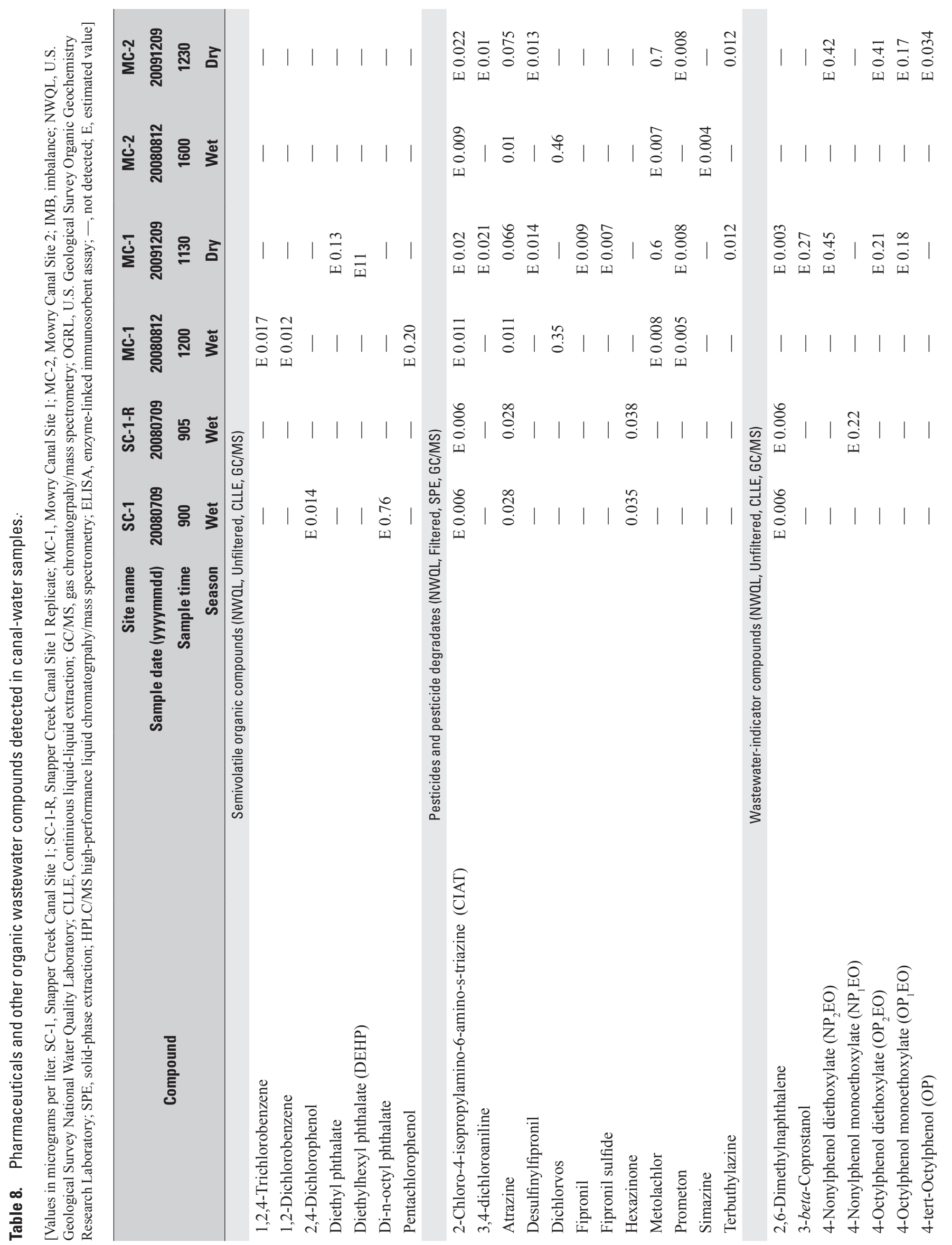




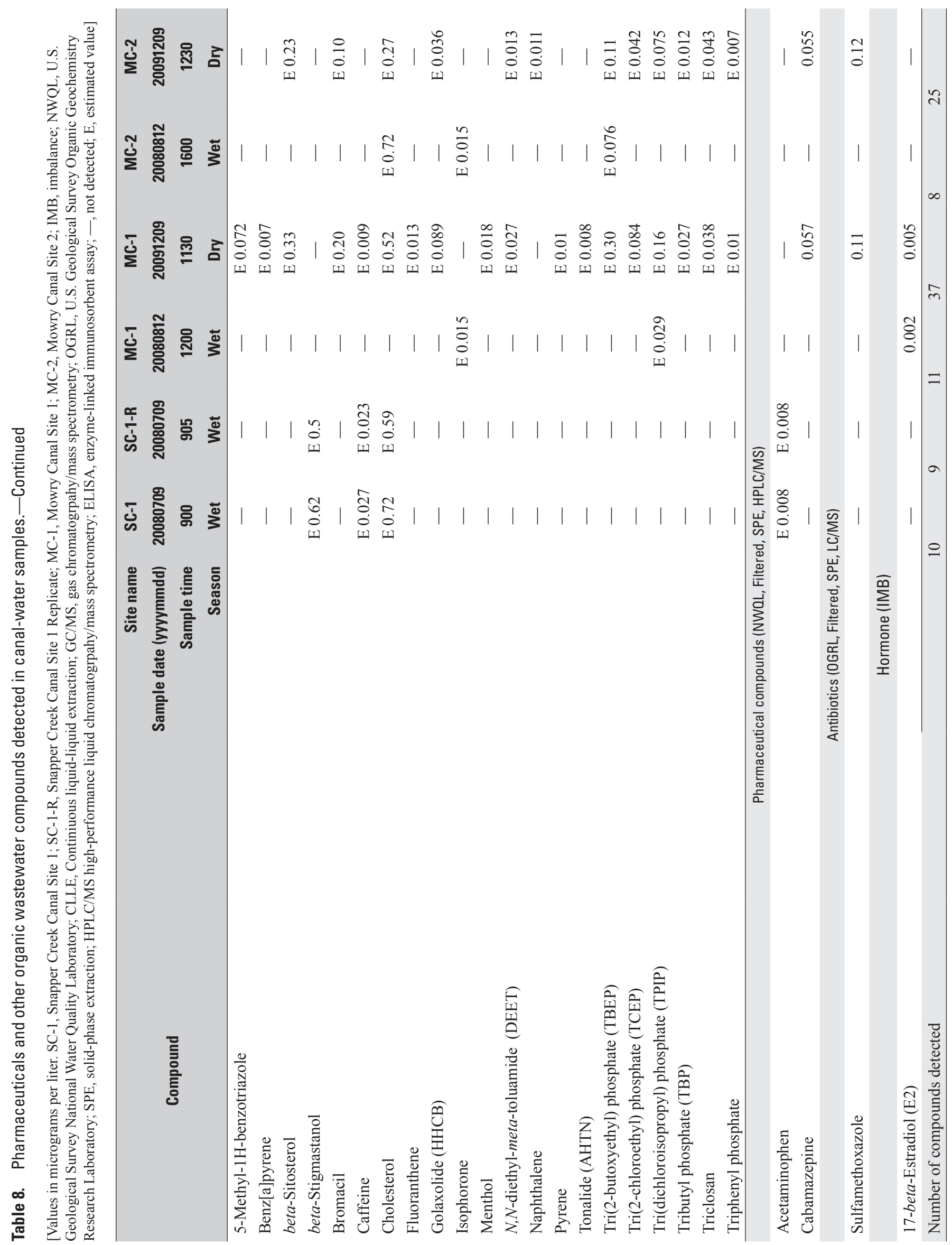


Figure 7. Comparison of wetand dry-season concentrations of pharmaceuticals and other organic wastewater compounds detected in canal-water samples collected from canal sampling sites MC-1 and MC-2 in Florida. Concentrations reported by the laboratory as less than the method reporting level are plotted as 0.001 micrograms per liter.
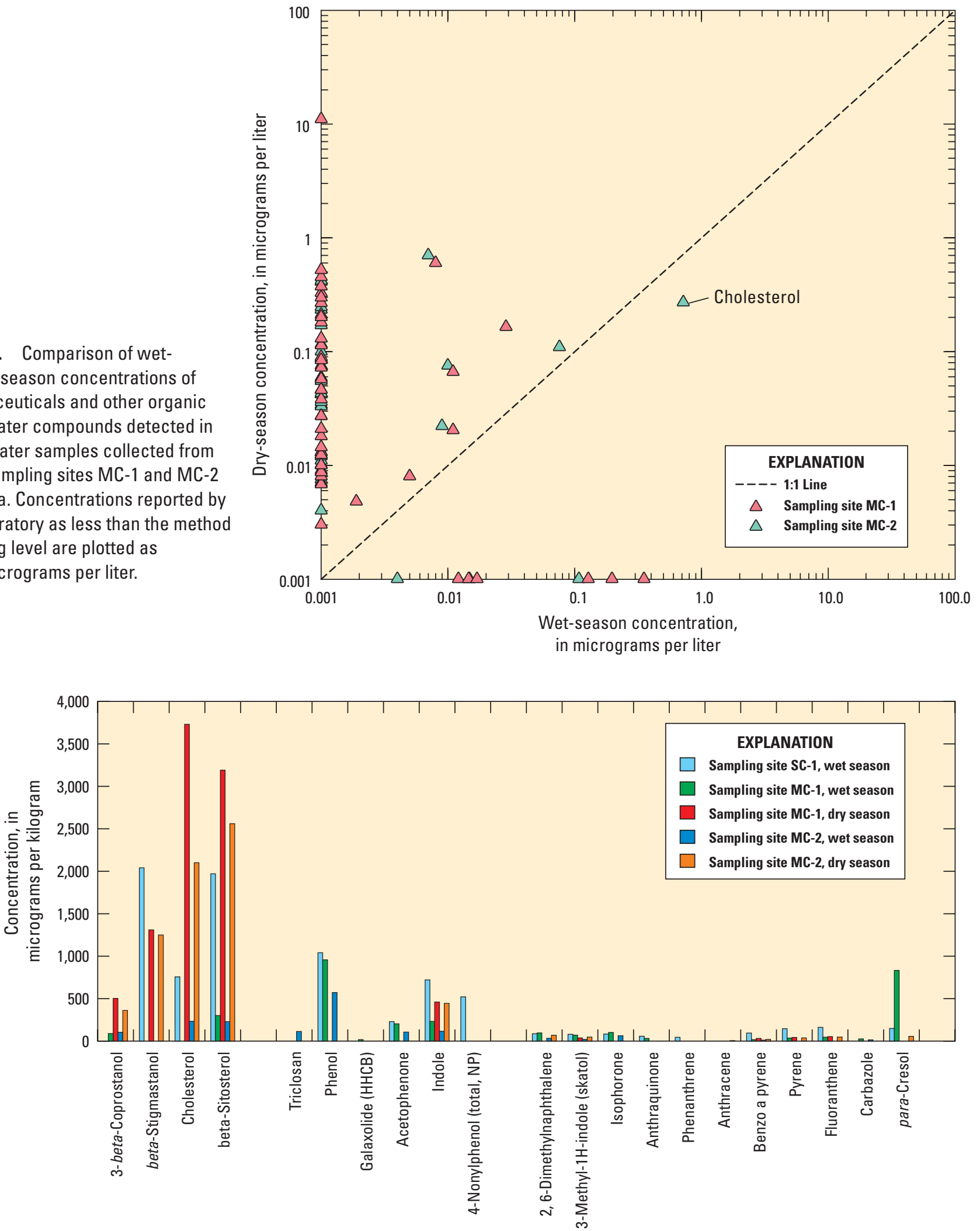

Figure 8. Concentrations of wastewater-indicator compounds in bed sediment samples collected from canal sampling sites SC-1, MC-1, and MC-2. 
Table 9. Wastewater-indicator compounds detected in canal bed sediment samples.

[Values in micrograms per kilogram ( $\mu \mathrm{g} / \mathrm{kg}$ ). SC-1, Snapper Creek Canal Site 1; SC-1-R, Snapper Creek Canal Site 1 Replicate; MC-1, Mowry Canal Site 1; MC-2, Mowry Canal Site 2; MRL, method reporting level; —, not detected; E, estimated]

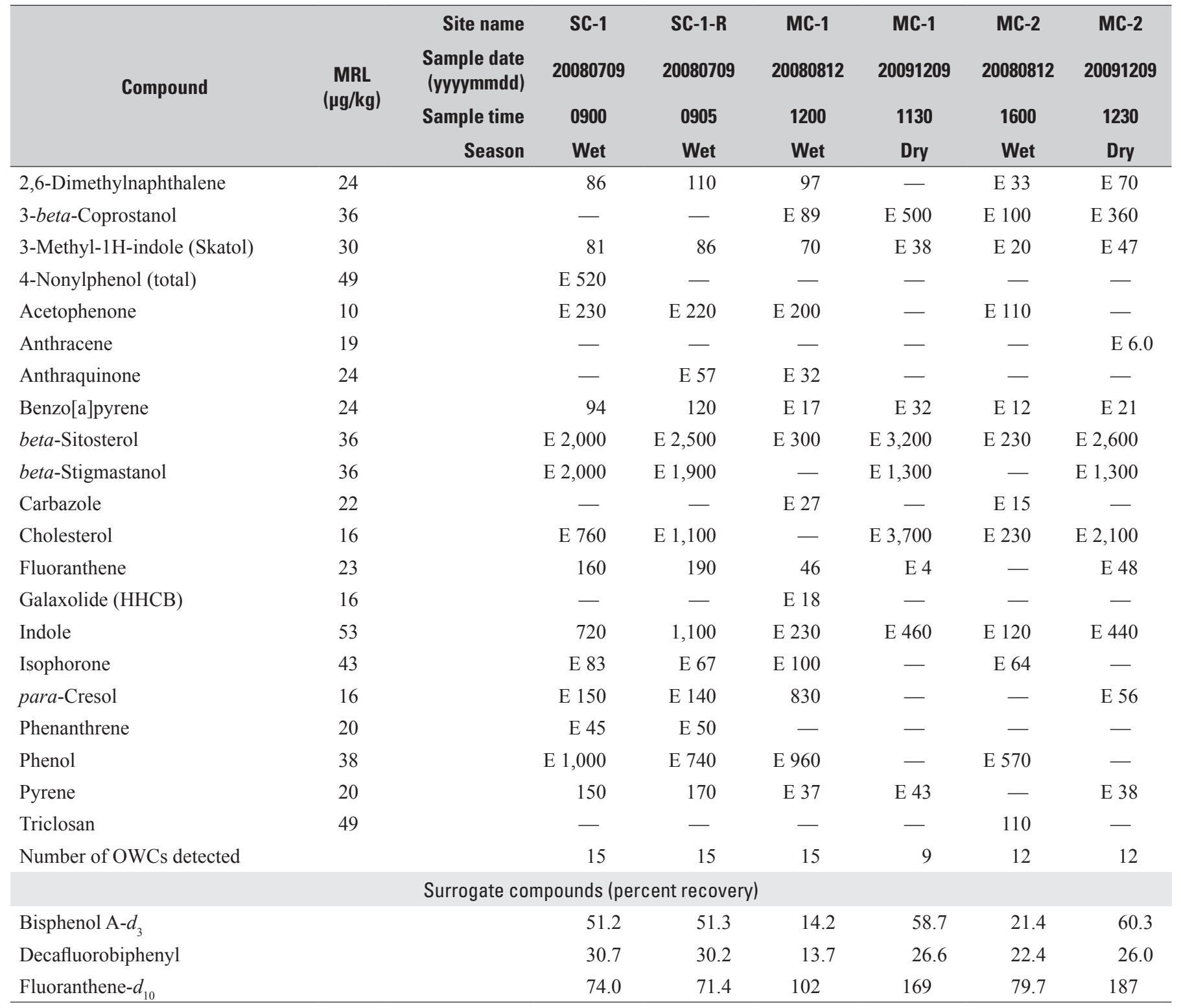




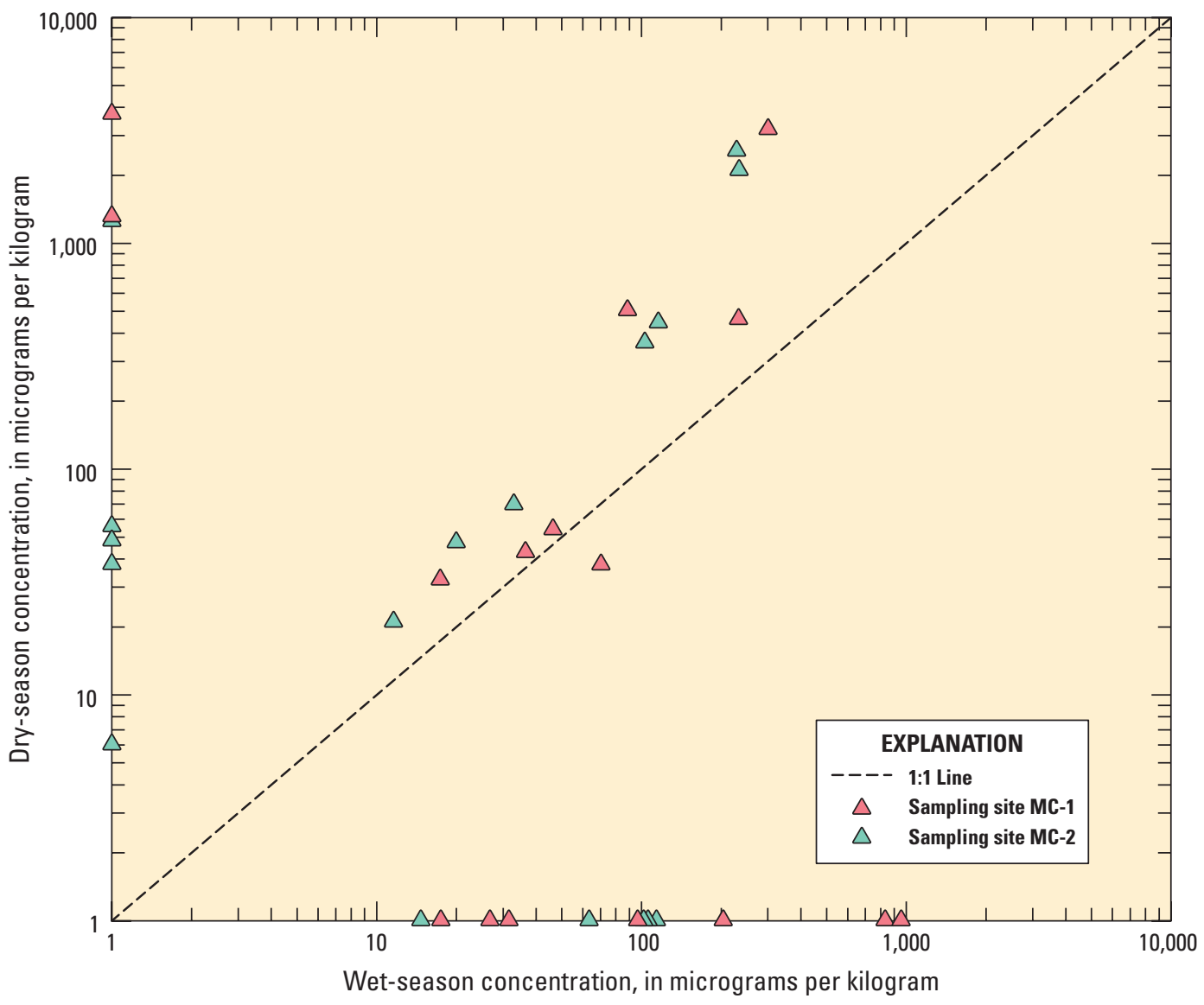

Figure 9. Comparison of wet- and dry-season concentrations of organic wastewater compounds in bed sediment samples collected from canal sampling sites MC-1 and MC-2 in Florida. Concentrations reported by the laboratory as less than the method reporting level are plotted as 1 microgram per kilogram.

the site approximately $1 \mathrm{mi}$ downstream, in the wet season. Conversely, more compounds were detected in sediments at MC-2 (12) than at MC-1 (9), in the dry season. The four biogenic sterols were detected at high concentrations (ranging from 89 to $3,700 \mathrm{mg} / \mathrm{kg}$ ) in bed sediments from both locations. Phenol was also detected at high concentrations (960 and 570 $\mathrm{mg} / \mathrm{kg}$ ) in bed sediments collected in the wet season.

Similar to canal water results, when it was possible to compare concentrations of a compound in bed sediments in both the wet and dry season at a particular site, concentrations were generally higher in the dry season (fig. 9; table 9). Some compounds were detected several orders of magnitude higher in the dry season than in the wet season. The higher concentrations in bed sediment in the dry season could be due to greater deposition of particulates during low-flow conditions in the dry season; however, the three surrogate compounds (bisphenol A- $d_{3}$, decafluorobiphenyl, and fluoranthene- $d_{10}$ ) had lower percent recoveries in the wet-season samples compared to the dry-season samples (table 9), thus indicating the extraction method did not perform as well on the wet-season samples. This result could partially explain the lower concentrations of wastewater-indicator compounds in bed sediments collected in the wet season. Only one compound (3-methyl-1H-indole (skatol), MC-1) was detected at a higher concentration in the wet season.

Similar to the water samples collected from SC-1, bed sediment collected at SC-1 contained detectable quantities of 16 wastewater-indicator compounds (fig. 8; table 9). Some of the compounds detected in the bed sediment sample at SC-1 (including 3-methyl-1H-indole and the four biogenic sterols3-beta-coprostanol, beta-sitosterol, beta-stigmastanol and cholesterol) do have non-anthropogenic sources, which can partially explain the presence of these compounds. However, the presence of other compounds, such as 4-nonylphenol and isophorone, which are strictly anthropogenic, as well as the 11 compounds detected in water samples (mentioned in the previous discussion), further suggests the presence of a nonpoint source of wastewater to the canal. 


\section{Summary and Conclusions}

The U.S. Geological Survey in cooperation with the Miami-Dade Water and Sewer Department (WASD) and the Department of Environmental Resources Management (DERM), initiated a study to assess the presence of pharmaceuticals and other organic wastewater compounds in influent and effluent at four wastewater-treatment plants (WWTPs) in Miami-Dade County during 2008 and 2009. A Lagrangian sampling scheme was used at each plant to collect 24-hour (hr) flow-weighted composite samples from the influent and effluent. Samples were collected at each plant in both the dry (lowflow) and wet (high-flow) seasons to determine any seasonal variations in concentrations.

Water samples were analyzed for approximately 210 organic compounds including: semivolatile organic compounds (SVOCs), pesticides and pesticide degradates, wastewater-indicator compounds, prescription and nonprescription pharmaceuticals, antibiotics, and one hormone (17-beta-estradiol).

Influent samples at each plant contained a complex mixture of organic compounds reflecting the diversity of incoming domestic, municipal, and industrial waste. Compounds detected in 24-hr flow-weighted influent composite samples included: 20 SVOCs, 12 pesticides and pesticide degradates, 52 wastewater-indicator compounds, 5 pharmaceuticals, 14 antibiotics, and the hormone 17-beta-estradiol. Wastewater-indicator compounds accounted for nearly all of the total concentrations in each influent sample collected. Two biogenic sterols, cholesterol and 3-beta-coprostanol, had the highest median concentrations (91 and 79 micrograms per liter $(\mu \mathrm{g} / \mathrm{L})$, respectively), while diethylhexyl phthalate, a widely used plasticizer and inert ingredient in pesticide products, showed the greatest concentration range ( 5.3 to $270 \mu \mathrm{g} / \mathrm{L}$ ). The total concentrations in influent samples collected in the dry season were generally 10 to 30 percent higher than samples collected in the wet season.

Compounds detected in 24-hr flow-weighted effluent composite water samples included: 19 SVOCs, 13 pesticides, 49 wastewater-indicator compounds, 7 pharmaceuticals, 11 antibiotics, and 17-beta-estradiol. Concentrations of individual organic compounds in effluent samples were comparable with other reported values in WWTP effluent across the United States. Using total concentration in each effluent sample and average flows during sampling; estimated effluent loads were calculated and ranged from 0.3 to 25.7 pounds per day. Wastewater-indicator compounds accounted for greater than 64 percent of the total load at each plant. Loads were generally higher in the wet season at each plant, reflecting the higher flows during sample collection. Among the various groups of compounds, SVOCs and wastewater-indicator compounds generally had higher removal efficiencies than pharmaceuticals, antibiotics and pesticides.

The number of samples collected at each plant was small; only two samples were collected at each plant. The small number of samples was adequate for the primary objectives of this study, which were to document the occurrence of pharmaceuticals and other organic wastewater compounds in influent and effluent waters at WWTPs in the county and to determine any seasonal variations in concentrations, percent reduction, and effluent loads. The results suggest there are seasonal variations in both effluent concentrations and loads. To determine if these variations are statistically different, future studies will be needed to collect multiple samples during both seasons. It might be more efficient to analyze samples for compounds that are frequently detected in effluent waters and exclude less frequently detected compounds from target lists. Results of this study provide a basis on which compounds could be selected in follow-up studies. Analytical chemists are continually improving analytical methods for the low-level detection of organic compounds in complex environmental matrices. As extraction methods improve and analytical detection levels become lower, an even broader range of organic compounds will be detectable. Future occurrence studies should consider if these new methods are applicable. Additionally, influent and effluent matrices are complex and highly variable; therefore any future studies should consider including a rigorous quality-assurance plan.

The WASD is currently seeking to increase the amount of wastewater reused from its regional wastewater-treatment plants, and is actively pursuing reuse plans for aquifer recharge, irrigation, and wetland rehydration. To investigate the fate of pharmaceuticals and other organic wastewater compounds in groundwater affected by WWTP effluent, water samples were collected from three monitoring wells at the Homestead WWTP in both the wet and dry seasons. For decades, this plant has been discharging tertiary-treated effluent directly to the water table. Generally, concentrations in the groundwater were below $0.5 \mu \mathrm{g} / \mathrm{L}$ with the exception of the fragrance, galaxolide (as high as $1.3 \mu \mathrm{g} / \mathrm{L}$ ), the antibiotic, sulfamethoxazole (as high as $0.57 \mu \mathrm{g} / \mathrm{L}$ ), and the flame retardant, tri(2-butoxyethyl)phosphate (detected in one sample at E $0.51 \mu \mathrm{g} / \mathrm{L}$ ). The attenuation of pharmaceuticals and other organic wastewater compounds in groundwater at the HSWWTP was evident by lower concentrations in groundwater samples compared with effluent samples, likely from biodegradation and dilution with recharge water from upgradient locations. Nine compounds were detected in groundwater samples that were not detected in effluent samples. The presence of these compounds in groundwater at this site could be from chemical reactions occurring in the subsurface after disposal or possibly from sources other than the WWTP. Concentrations of pharmaceuticals and other organic wastewater compounds were generally higher in groundwater samples collected in the wet season, which most likely reflects the higher loads of these compounds in the effluent during the wet season. A more in-depth geochemical study, one in which the three monitoring wells at the plant and other monitoring wells further downgradient of the HSWWTP are sampled and analyzed for major ions, trace metals, and dissolved gasses as well as the isotopic analysis of oxygen-, carbon-, hydrogen-, and nitrogen-bearing materials, may be worthwhile to 
delineate the plume and help to understand the ultimate fate of these compounds as they are transported offsite.

Surface-water and bed sediments samples were collected from two canal sites near the Homestead WWTP to determine if constituents originating from the effluent could be transported from the groundwater to the canal. These locations were sampled once in the dry season and once in the wet season to determine any seasonal variations. A total of 51 compounds were detected in one or more canal water sample collected at concentrations generally below $1.0 \mu \mathrm{g} / \mathrm{L}$. Results from seasonal sampling from the two canals sites show concentrations of pharmaceuticals and other organic wastewater compounds were generally higher in the dry season.

Detection of pharmaceuticals and other organic wastewater compounds in water and sediment samples collected at SC-1 suggests that even away from wastewater-treatment facilities, these compounds may be present in canals from unknown sources, thus it may be difficult to link organic wastewater compounds in surface water to a municipal wastewater sources. A more detailed water- quality study, one in which multiple canal sites throughout the study area are sampled, might help resolve the source of these compounds to the canals, or at least identify areas where these compounds are more frequently detected.

\section{References}

Andersen, H., Siegrist, H., Halling-Sorensen, B., and Ternes, T.A., 2003, Fate of estrogens in a municipal sewage treatment plant: Environmental Science and Technology, v. 37, no. 18 , p. $4021-4026$.

Barnes, K.K., Christenson, S.C., Kolpin, D.W., Focazio, M.J., Furlong, E.T., Zaugg, S.D., Meyer, M.T., and Barber, L.B., 2004, Pharmaceuticals and other waste water contaminants within a leachate plume downgradient of a municipal landfill: Ground Water Monitoring and Remediation, v. 24, no. 2, p. 119-126.

Barber, L.B., Lee, K.E., Swackhamer, D.L., Schoenfuss, H.L., 2007, Reproductive responses of male fathead minnows exposed to wastewater treatment plant effluent, effluent treated with XAD8 resin, and an environmentally relevant mixture of alkylphenol compounds: Aquatic Toxicology, v. 82, no. 1, p. 36-46, doi:10.1016/j.aquatox.2007.01.003.

Barnes, K.K., Kolpin, D.W., Focazio, M.J., Furlong, E.T., Meyer, M.T., Zaugg, S.D., Haack, S.K., Barber, L.B., and Thurman, E.M., 2008, Water-quality data for pharmaceuticals and other organic wastewater contaminants in ground water and in untreated drinking water sources in the United States, 2000-01: U.S. Geological Survey Open-File Report 2008-1293, 7 p. plus tables.
Batt, A.L., Snow, D.D., and Aga, D.S., 2006, Occurrence of sulfonamide antimicrobials in private water wills in Washington County, Idaho, USA: Chemosphere, v. 64, no. 11, p. 1963-1971.

Bradner, A., McPherson, B.F., Miller, R.L., Kish, G., and Bernard, B., 2005, Quality of ground water in the Biscayne aquifer in Miami-Dade, Broward, and Palm Beach Counties, Florida, 1996-1998, with Emphasis on Contaminants: U.S. Geological Survey Open-File Report 2004-1438, 20 p.

Burkhardt, M.R., Zaugg, S.D., Smith, S.G., and ReVello, R.C., 2006, Determination of wastewater compounds in sediment and soil by pressurized solvent extraction, solid-phase extraction, and capillary-column gas chromatography/ mass spectrometry: U.S. Geological Survey Techniques and Methods, book 5, chap. B2, 40 p.

Cahill, J.D., Furlong, E.T., Burkhardt, M.R., Kolpin, D.W., and Anderson, L.G., 2004, Determination of pharmaceutical compounds in surface- and ground-water samples by solidphase extraction and high-performance liquid chromatography--electrospray ionization mass spectrometry: Journal of Chromatography A, v. 1041, no. 1-2, p. 171-180, doi: 10.1016/j.chroma.2004.04.005.

Clara, M., Strenn, B., and Kreuzinger, N., 2004, Carbamazepine as a possible anthropogenic marker in the aquatic environment: investigations on the behavior of carbamazepine in wastewater treatment and during groundwater infiltration: Water Research, v. 38, p. 947-954.

Clara, M., Windhofer, G., Hartl, W., Braun, K., Simon, M., Gans, O., Scheffknecht, C., and Chovanec, A., 2010, Occurrence of phthalates in surface runoff, untreated and treated wastewater and fate during wastewater treatment: Chemosphere, v. 78, no. 9, p. 1078-1084.

Cordy, G.E., Duran, N.L., Bouwer, H., Rice, R.C., Furlong, E.T., Zaugg, S.D., Meyer, M.T., Barber, L.B., and Kolpin, D.W., 2004, Do pharmaceuticals, pathogens, and other organic waste water compounds persist when waste water is used for recharge?: Ground Water Monitoring and Remediation, v. 24, no. 2, p. 58-69.

Cunningham, K.J., Carlson, J.L., Wingard, G.L., Robinson, E., and Wacker, M.A., 2004, Characterization of aquifer heterogeneity using cyclostratigraphy and geophysical methods in the upper part of the karstic Biscayne aquifer, Southeastern Florida: U.S. Geological Survey Water-Resources Investigations Report 03-4208, 66 p., 5 apps. (on CD), and 5 pls.

Dargnat C., Teil M., Chevreuil M., and Blanchard M., 2009, Phthalate removal throughout wastewater treatment plant Case study of Marne Aval station (France): Science of the Total Environment, v. 407, p. 1235-1244. 
Farre, M., Brix, R., Kuster, M., Rubio, F., Goda, Y., Lopez de Alda, M.J., and Barcelo, D., 2006, Evaluation of commercial immunoassays for the detection of estrogens in water by comparison with high-performance liquid chromatography tandem mass spectrometry HPLC-MS/MS (QqQ): Analytical and Bioanalytical Chemistry, v. 385, p. 1001-1011.

Fish, J.E., and Stewart, M.T., 1991, Hydrogeology of the surficial aquifer system, Dade County, Florida: U.S. Geological Survey Water-Resources Investigations Report 90-4108, 56 p.

Fishman, M.J., ed., 1993, Methods of analysis by the U.S. Geological Survey National Water Quality Laboratory--Determination of inorganic and organic constituents in water and fluvial sediments: U.S. Geological Survey Open-File Report 93-125, 217 p.

Florida Department of Environmental Protection, 2010, 2008 Reuse Inventory: Tallahassee, Florida Department of Environmental Protection.

Foster, A.L., and Katz, B.G., 2010, Occurrence of organic compounds in source and finished samples from seven drinkingwater treatment facilities in Miami-Dade County, Florida, 2008: U.S. Geological Survey Data Series 550, 22 p.

Furlong, E.T., Werner, S.L., Anderson, B.D., and Cahill, J.D., 2008, Methods of analysis by the U.S. Geological Survey National Water Quality Laboratory determination of humanhealth pharmaceuticals in filtered water by chemically modified styrene-divinylbenzene resin-based solid-phase extraction and high-performance liquid chromatography/ mass spectrometry: U.S. Geological Survey Techniques and Methods, book 5, sec. B, chap. B5, 56 p.

Heberer, T., Mechlinkski, A., Fanck, B., Knappe, A., Massmann, G., Pekdeger, A., and Fritz, B., 2004, Field studies on the fate and transport of pharmaceutical residues in bank filtration: Ground Water Monitoring and Remediation, v. 24, no. 2, p. 70-77.

Kinney, C.A., Furlong, E.T., Werner, S.L., and Cahill, J.D., 2006, Presence and distribution of wastewater-derived pharmaceuticals in soil irrigated with reclaimed water: Environmental Toxicology and Chemistry, v. 25, no. 2, p. 317-326, doi: 10.1897/05-187R.1.

Kolpin, D.W., Furlong, E.T., Meyer, M.T., Thurman, E.M., Zaugg, S.D., Barber, L.B., and Buxton, H.T., 2002, Pharmaceuticals, hormones, and other organic wastewater constituents in U.S. streams, 1999-2000: A national reconnaissance: Environmental Science and Technology, v. 36, no. 6, p. 1202-1211.

Lietz, A.C., and Meyer, M.T., 2006, Evaluation of emerging contaminants of concern at the South District Wastewater Treatment Plant based on seasonal events, Miami-Dade County, Florida, 2004: U.S. Geological Survey Scientific Investigations Report 2006-5240, 38 p.
Lindsey, B.D., Berndt, M.P., Katz, B.G., Ardis, A.F., and Skach, K.A., 2009, Factors affecting water quality in selected carbonate aquifers in the United States, 1993-2005: U.S. Geological Survey Scientific Investigations Report 2008-5240, $117 \mathrm{p}$.

Meyer, J., and Bester, K., 2004, Organophosphate flame retardants and plasticisers in wastewater treatment plants: Journal of Environmental Monitoring, v. 6, p. 599-605.

Meyer, M.T., Lee, E.A., Ferrell, G.M., Bumgarner, J.E., and Varns, J., 2007, Evaluation of offline tandem and online solid-phase extraction with liquid chromatography/electrospray ionization-mass spectrometry for analysis of antibiotics in ambient water and comparison to an independent method: U.S. Geological Survey Scientific Investigations Report 2007-5021, 28 p.

Moon, H., Yoon, S., Jung, R., and Choi, M., 2008, Wastewater treatment plants (WWTPs) as a source of sediment contamination by toxic organic pollutants and fecal sterols in a semi-enclosed bay in Korea: Chemosphere, v. 73, p. $880-889$.

National Oceanic and Atmospheric Agency (NOAA), 2004, Climatography of the United States No. 20 Monthly Station Climate Summaries for the 1971-2000: National Climatic Data Center, accessed 2011 at http://www.ncdc.noaa.gov/ normals.html.

National Research Council, 1998, Issues in Potable Reuses The Viability of Augmenting Drinking Water Supplies with Reclaimed Water, National Academy Press: Washington, DC, 1998.

Ngim, K.K., and Crosby, D.G., 2001, Abiotic processes influencing fipronil and desthiofipronil dissipation in California, USA, rice fields: Environmental Toxicology and Chemistry, v. 20 , no. 5 , p. $972-977$.

Pehlivanoglu-Mantas, E., Hawley, E.L., Deeb, R.A., and Sedlak, D.L., 2006, Formation of nitrosodimethylamine (NDMA) during chlorine disinfection of wastewater effluents prior to use in irrigation systems: Water Research, v. 40 , p. $341-347$.

Phillips, P.J., Smith, S.G., Kolpin, D.W., Zaugg, S.D., Buxton, H.T., Furlong, E.T., Esposito, Kathleen, and Stinson, Beverley, 2010, Pharmaceutical formulation facilities as sources of opioids and other pharmaceuticals to wastewater treatment plant effluents: Environmental Science and Technology, v. 44, no. 13, p. 4910-4916.

Renken, R.A., Cunningham, K.J., Shapiro, A.M., Harvey, R.W., Zygnerski, M.R., Metge, D.W., and Wacker, M.A., 2008, Pathogen and chemical transport in the karst limestone of the Biscayne aquifer: 1. Revised conceptualization of groundwater flow: Water Resources Research, v. 44, 16 p. 
Sando, S.K., Furlong, E.T., Gray, J.L., Meyer, M.T., and Bartholomay, R.C., 2005, Occurrence of organic wastewater compounds in wastewater effluent and the Big Sioux River in the Upper Big Sioux River Basin, South Dakota, 2003-2004: U.S. Geological Survey Scientific Investigations Report 2005-5249, 108 p.

Sandstrom, M.W., Stroppel, M.E., Foreman, W.T., and Schroeder, M.P., 2001, Methods of analysis by the U.S. Geological Survey National Water Quality Laboratory-Determination of moderate-use pesticides and selected degradates in water by $\mathrm{C}-18$ solid-phase extraction and gas chromatography/mass spectrometry: U.S. Geological Survey Water-Resources Investigations Report 01-4098, $70 \mathrm{p}$.

Schultz, M.M., Furlong, E.T., Kolpin, D.W., Werner, S.L., Schoenfuss, H.L., Barber, L.B., Blazer, V.S., Norris, D.O., and Vajda, A.M., 2010, Antidepressant pharmaceuticals in two U.S. effluent-impacted streams--Occurrence and fate in water and sediment, and selective uptake in fish neural tissue: Environmental Science and Technology, v. 44, no.6, p. 1918-1925, doi:10.1021/es9022706

Stackelberg, P.E., Furlong, E.T., Meyer, M.T., Zaugg, S.D., Henderson, A.K., and Reissman, D.B., 2004, Persistence of pharmaceutical compounds and other organic wastewater contaminants in a conventional drinking-water-treatment plant: Science of the Total Environment, v. 329, p. 99-113.

Taylor, J.K., 1987, Quality-assurance of chemical measurements: Chelsea, Mich., Lewis Publishers, 328 p.

U.S. Environmental Protection Agency, 1994, Guidelines for Water Reuse. EPA/625/R-04/108. September 1994, 478 p.

U.S. Geological Survey, 2010, U.S.G.S. Toxic Substances Hydrology Program, 2010: U.S. Geological Survey Fact Sheet 2010-3011. (Also available at http://pubs.usgs.gov/ $f_{s} / 2010 / 3011 /$ )
U.S. Geological Survey, variously dated, National field manual for the collection of water-quality data: U.S. Geological Survey Techniques of Water-Resources Investigations, book 9, chaps. A1-A9. (Also available at http://pubs.water. usgs.gov/twri9A.)

Vajda, A.M., Barber, L.B., Gray, J.L., Lopez, E.M., Woodling, J.D., and Norris, D.O., 2008, Reproductive disruption in fish downstream from an estrogenic wastewater effluent: Environmental Science and Technology, v. 42, no. 9, p. 3407-3414, doi:10.1021/es0720661.

WaterReuse Foundation, 2008, National database of water reuse facilities summary report. 02-004-01. WaterReuse Foundation, Alexandria, Virginia, 2008

Wilkison, D.H., Armstrong, D.J., Norman, R.D., Poulton, B.C., Furlong, E.T., and Zaugg, S.D., 2006, Water quality in the Blue River basin, Kansas City metropolitan area, Missouri and Kansas, July 1998 to October 2004: U.S. Geological Survey Scientific Investigations Report 2006-5147, 170 p.

Writer, J.H., Barber, L.B., Ryan, J.N., and Bradley, P.M., 2011, Biodegradation and attenuation of steroidal hormones and alkylphenols by stream biofilms and sediments: Environmental Science and Technology, v. 45, no. 10, p. 4370-4376, doi:10.1021/es2000134.

Zaugg, S.D., Sandstrom, M.W., Smith, S.G., and Fehlberg, K.M., 1995, Methods of analysis by the U.S. Geological Survey National Water Quality Laboratory--Determination of pesticides in water by $\mathrm{C}-18$ solid-phase extraction and capillary-column gas chromatography/mass spectrometry with selected-ion monitoring: U.S. Geological Survey Open-File Report 95-181, 60 p.

Zaugg, S.D., Smith, S.G., and Schroeder, M.P., 2006, Determination of wastewater compounds in whole water by continuous liquid-liquid extraction and capillary-column gas chromatography/mass spectrometry: U.S. Geological Survey Techniques and Methods, book 5, chap. B4, 30 p. 


\section{Appendixes 1-4}

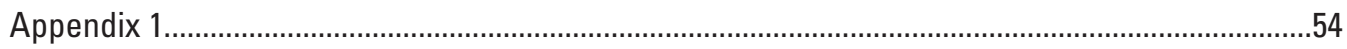

Appendix 2

Appendixes 3 and 4.........................available for download at $h t t p: / / p u b s . u s g s . g o v / s i r / 2012 / 5083 /$ 


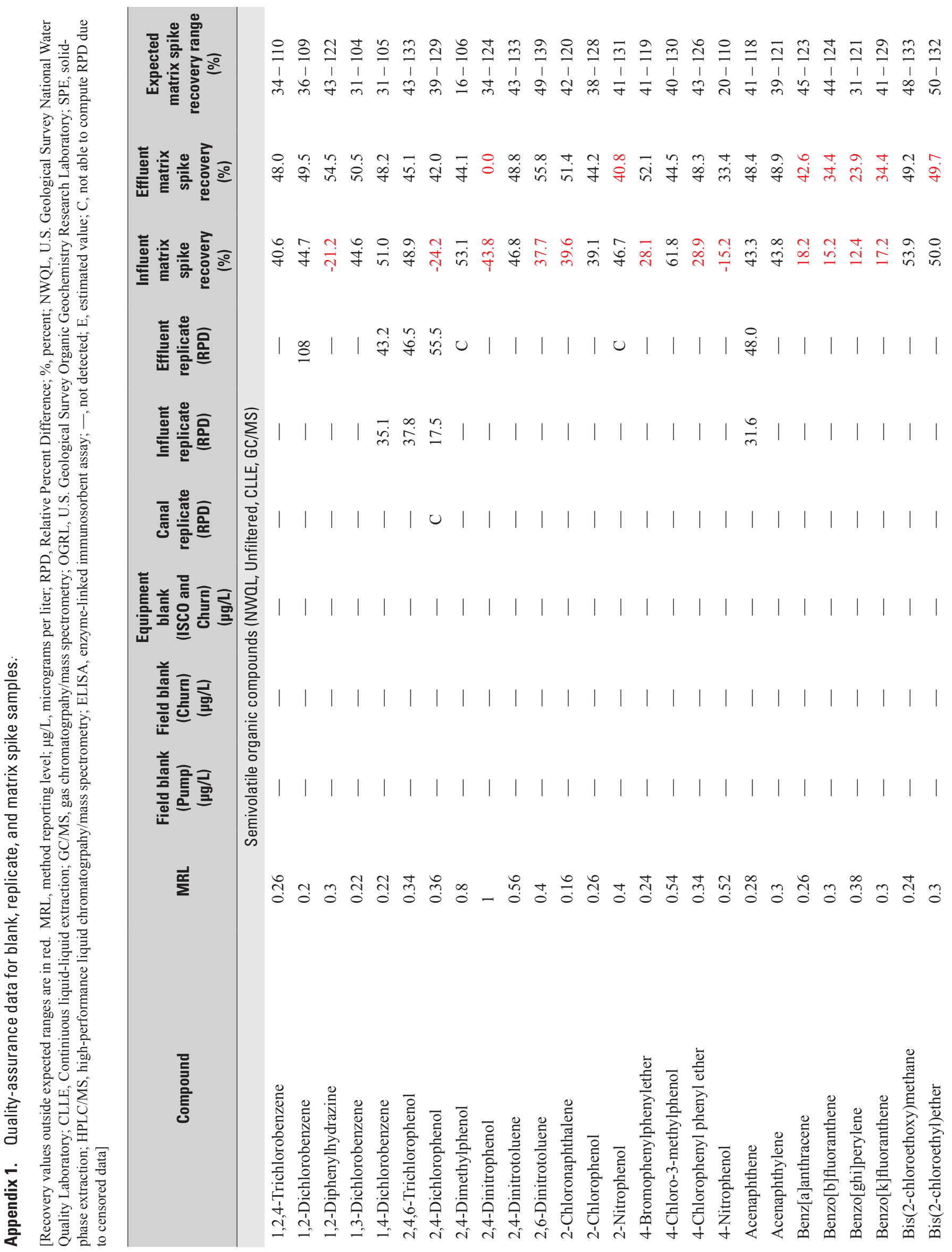




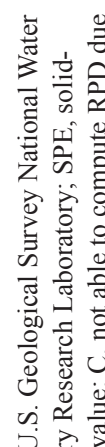

i.

会要

जี

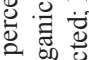

बे

仓े

एँ

额

定

웜

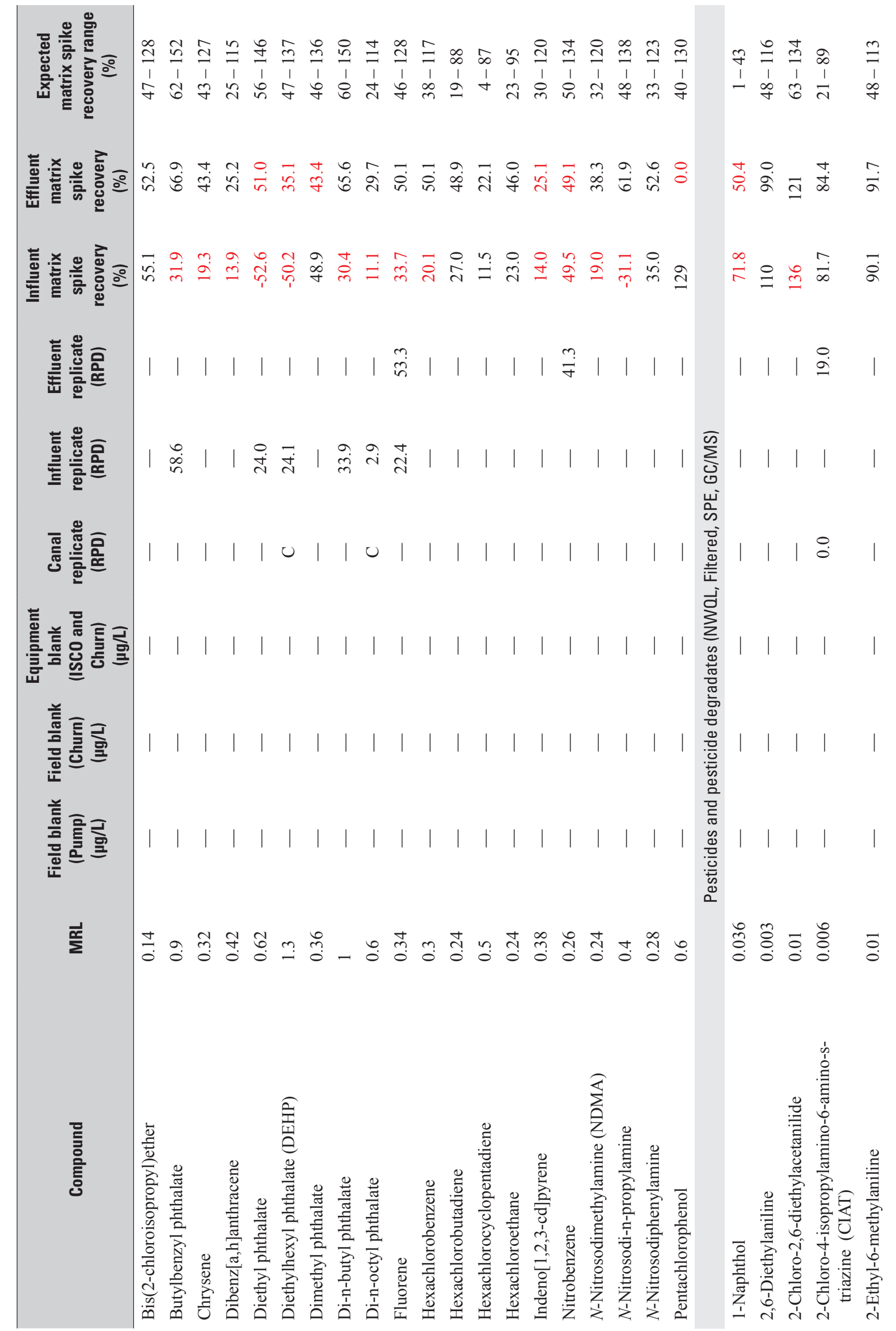




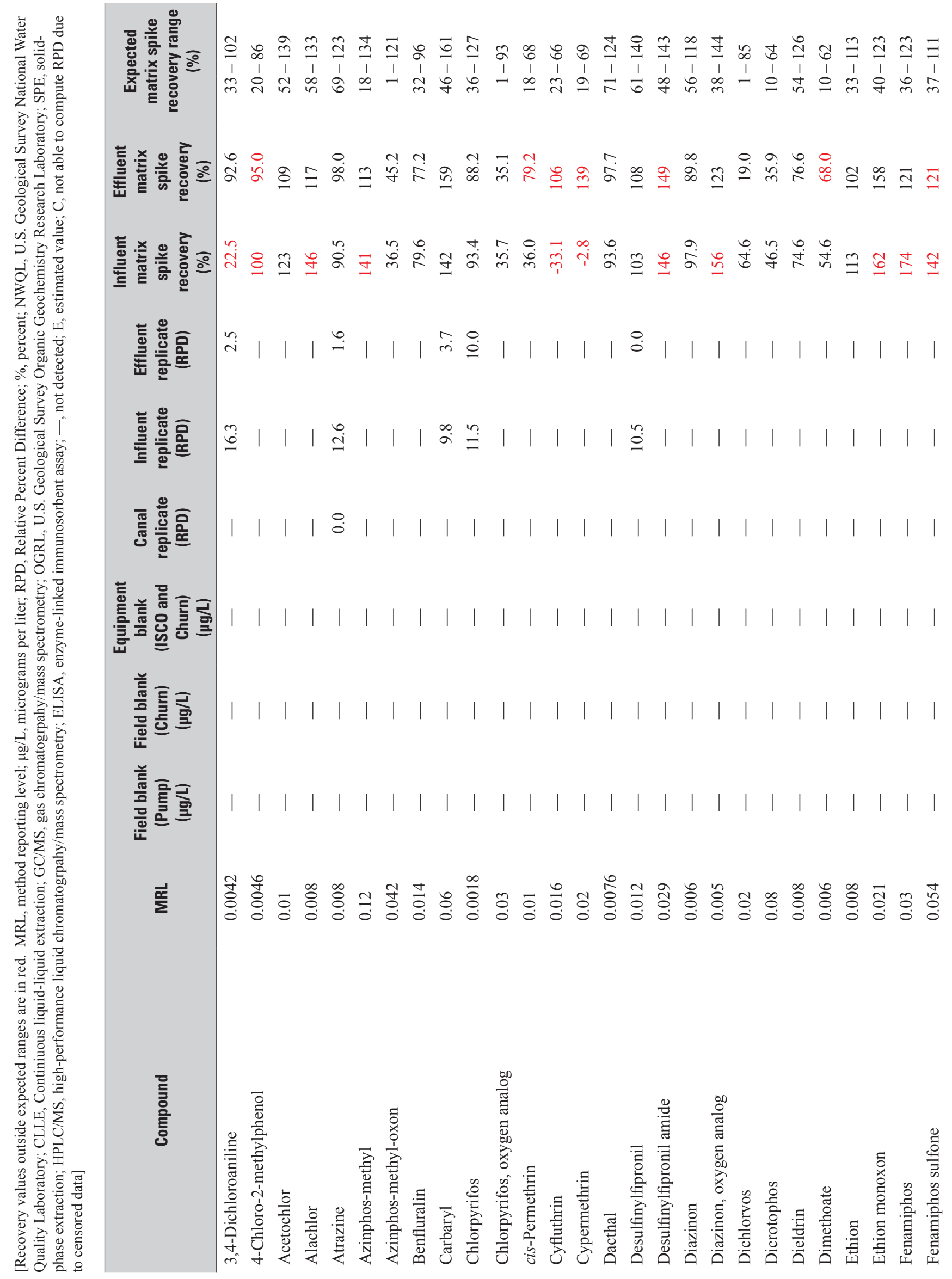




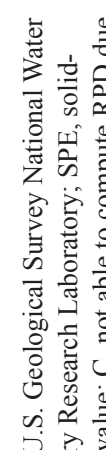

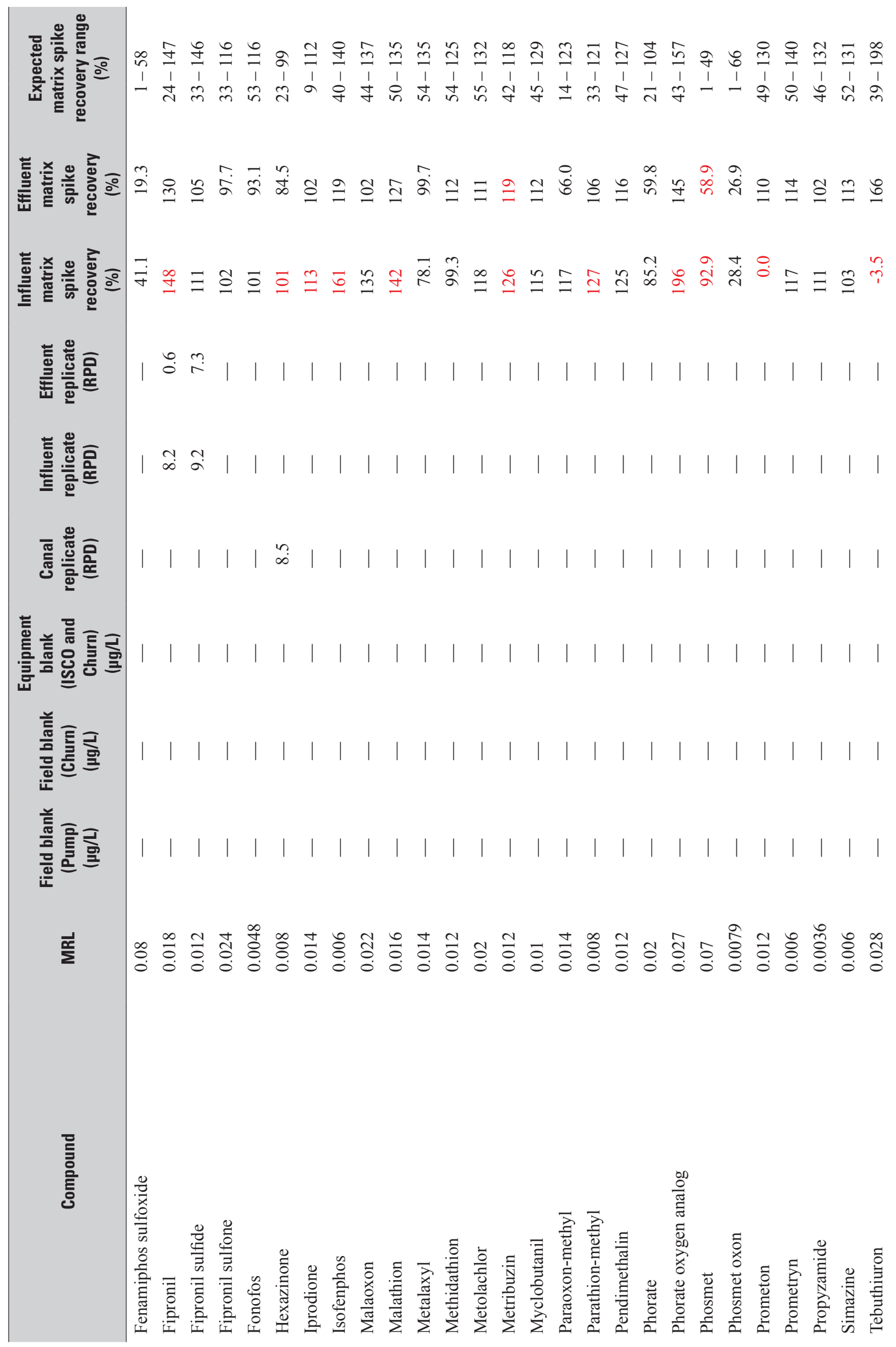

을

흘 


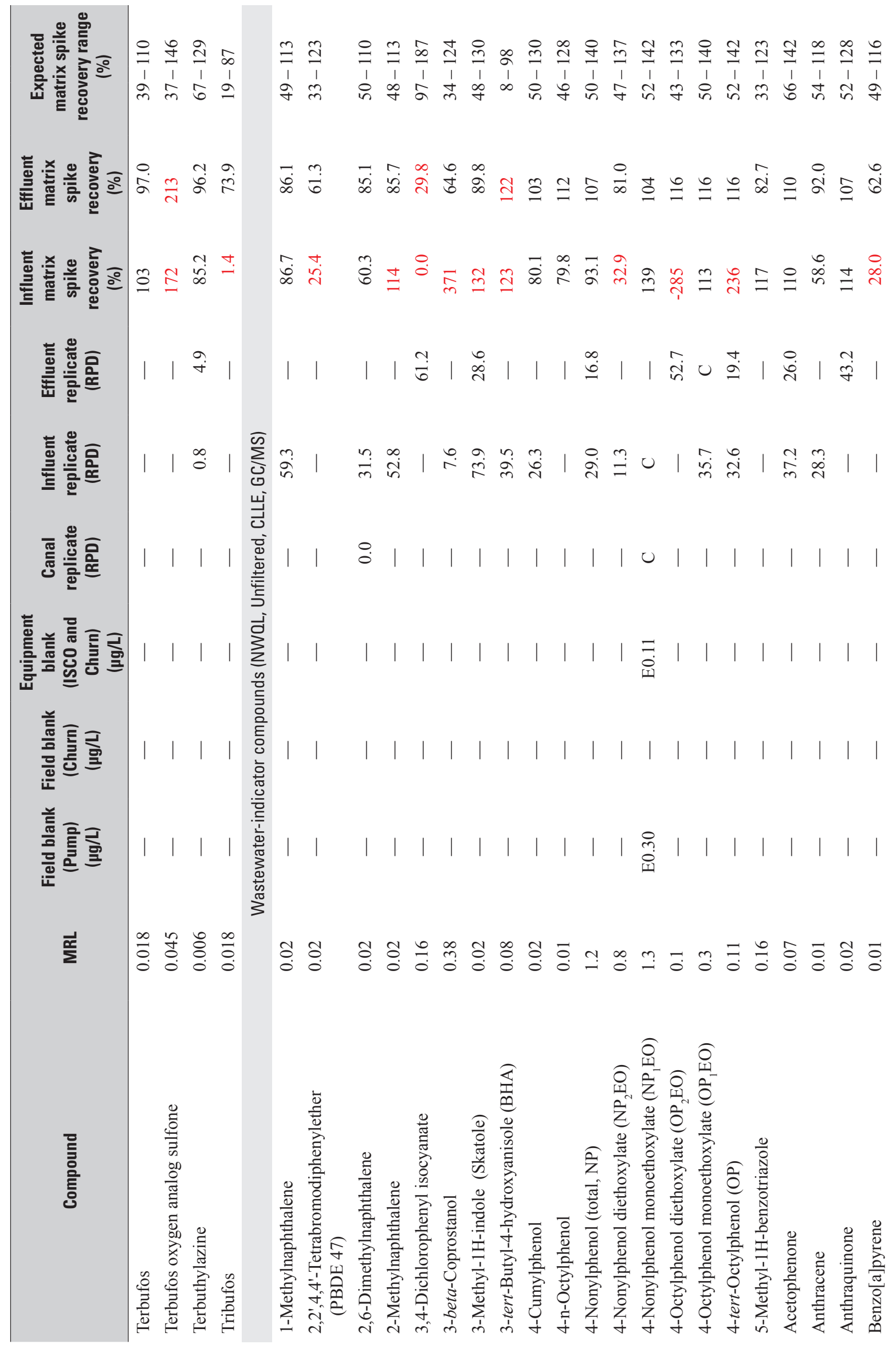




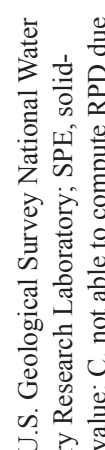

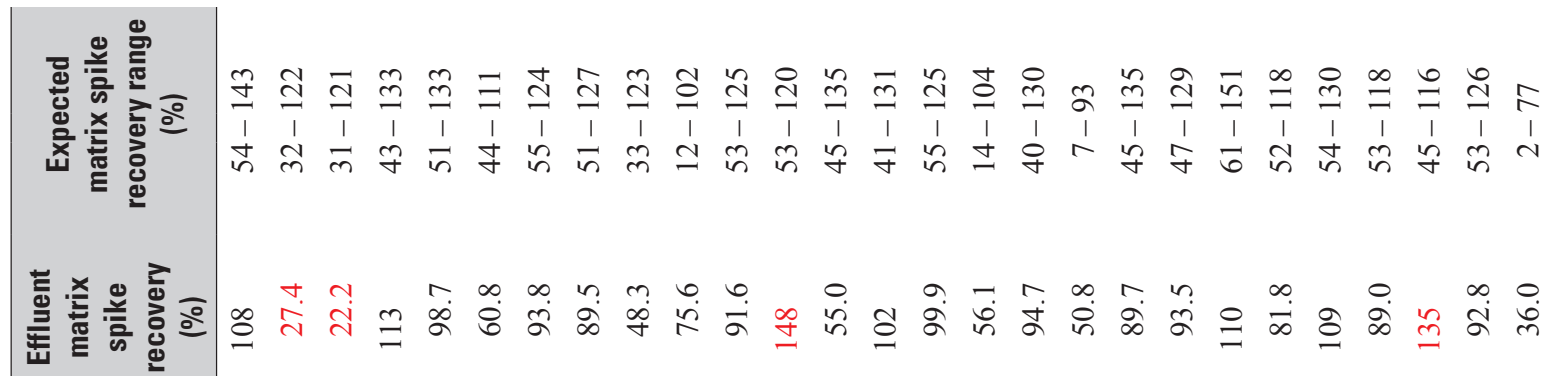

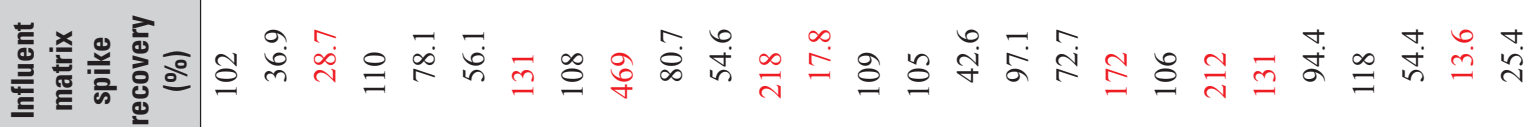

i. 을

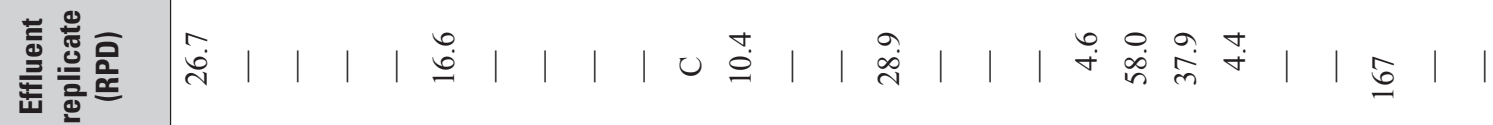

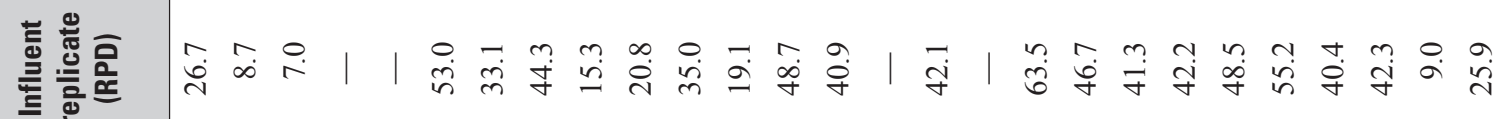

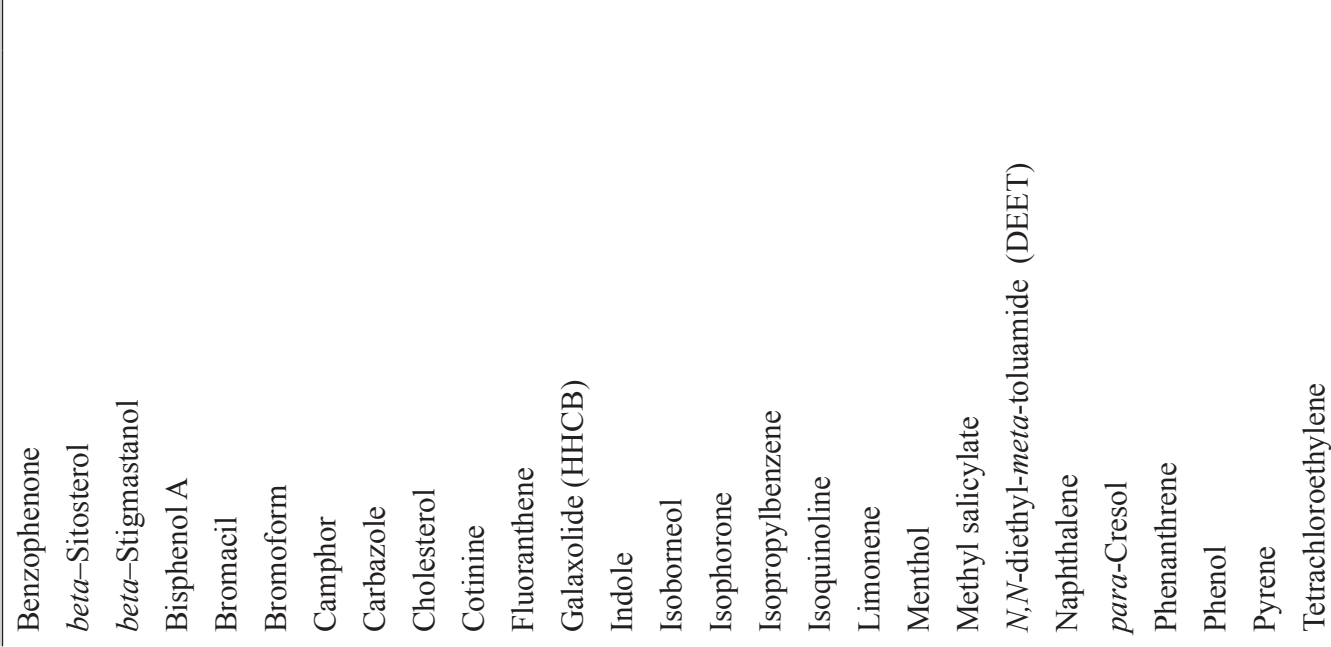




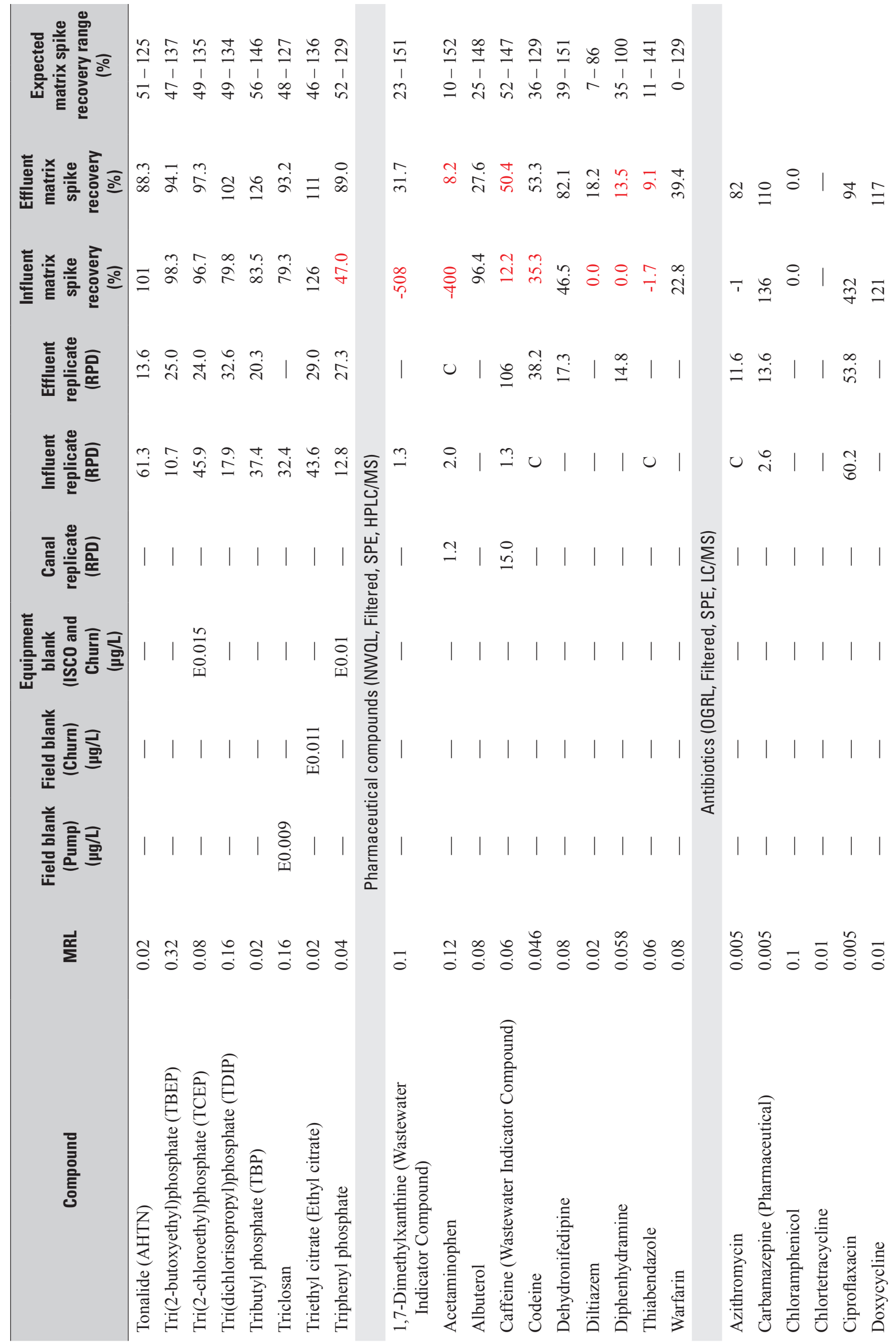



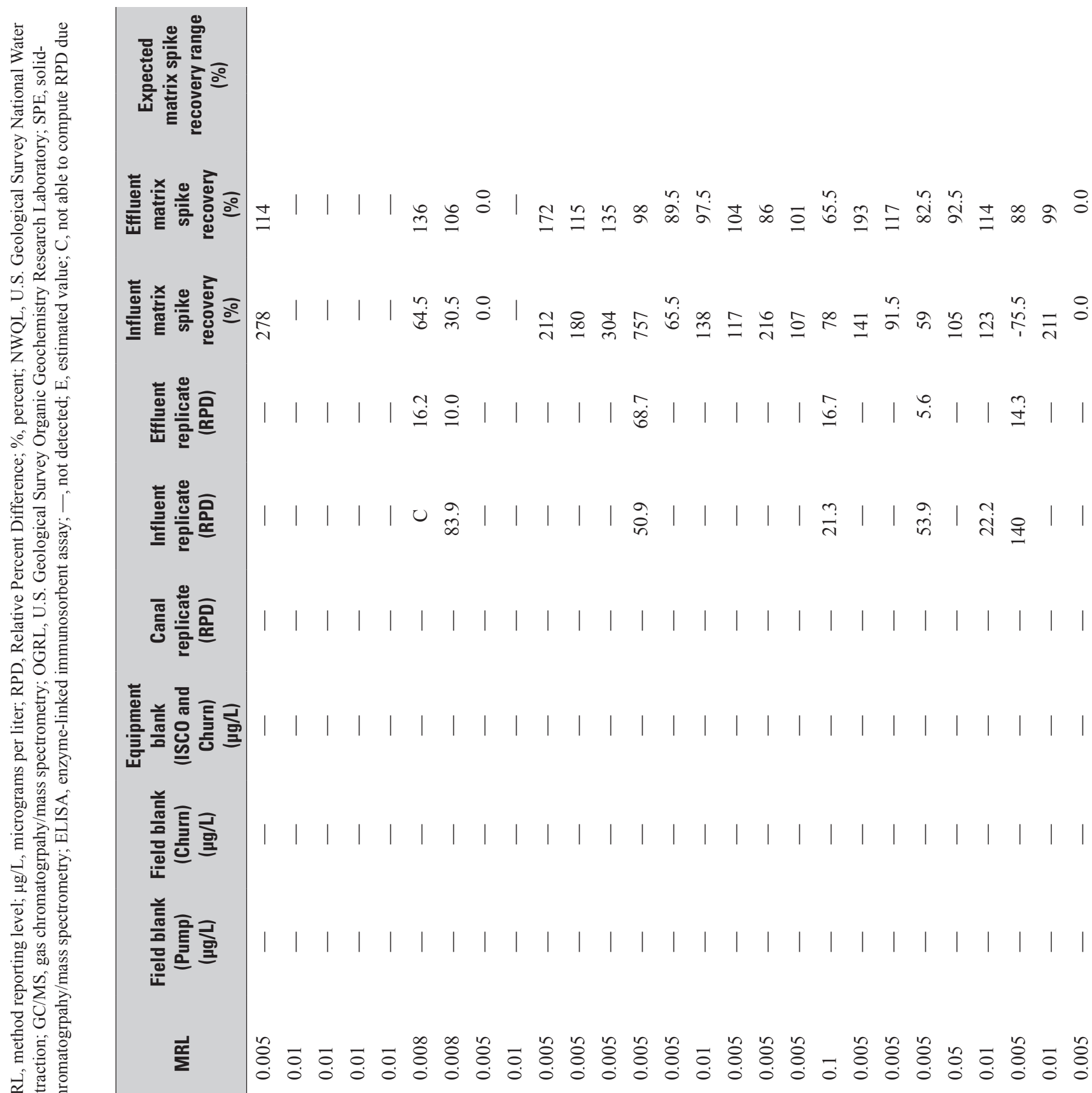


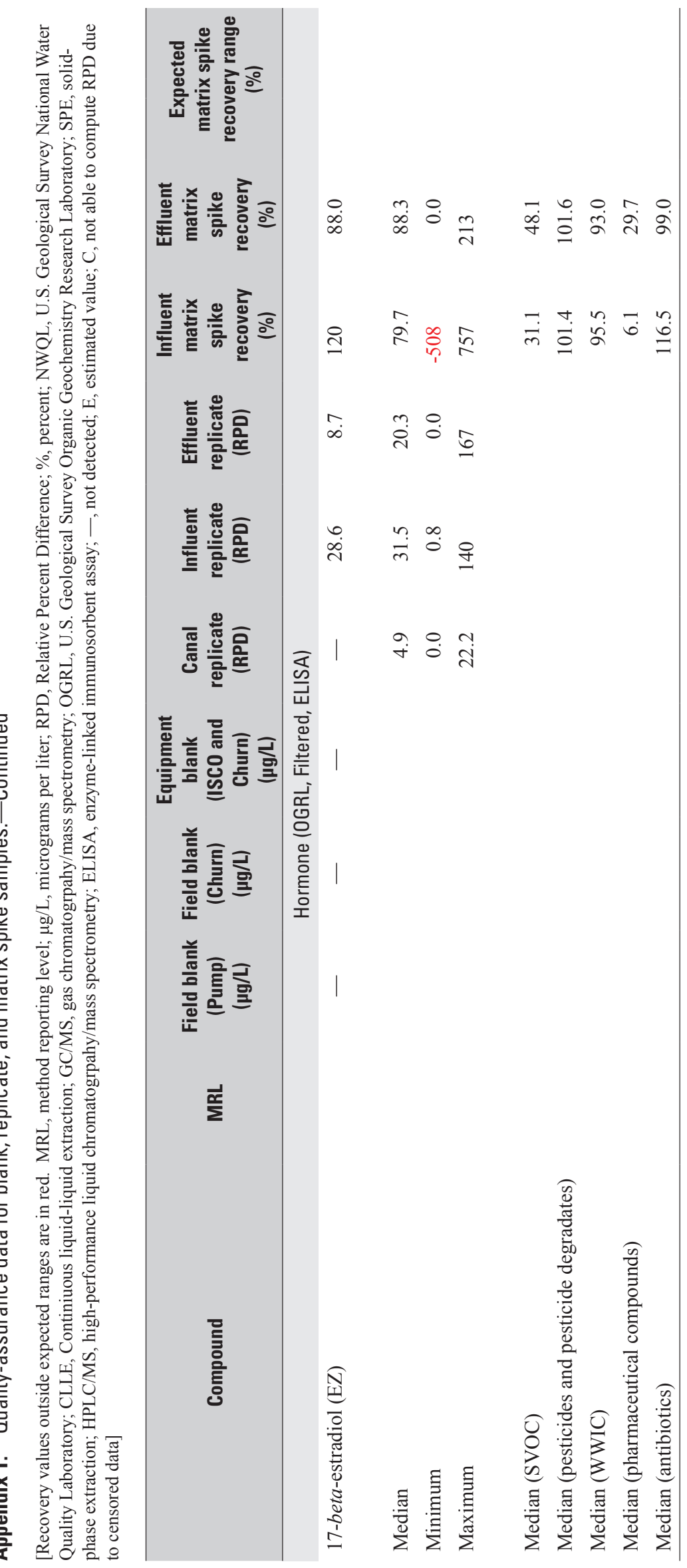




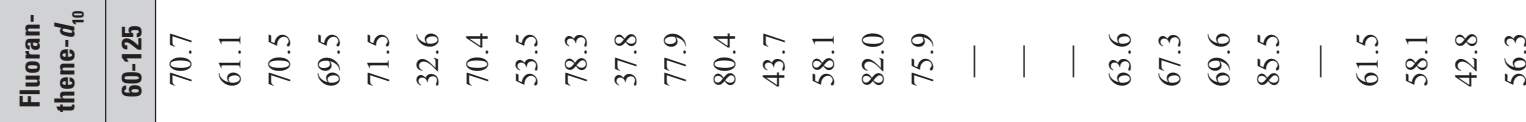

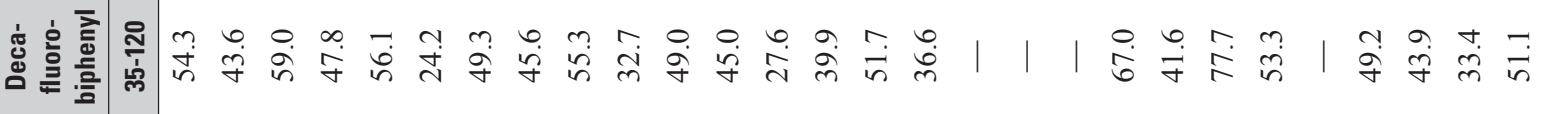

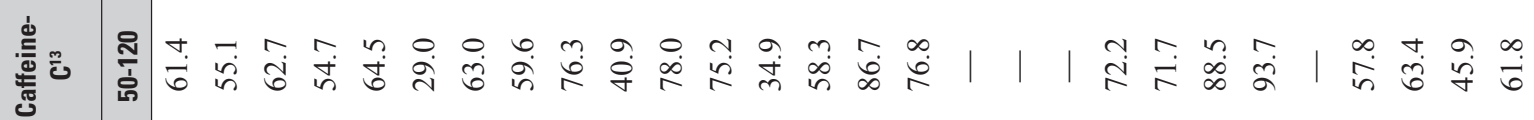

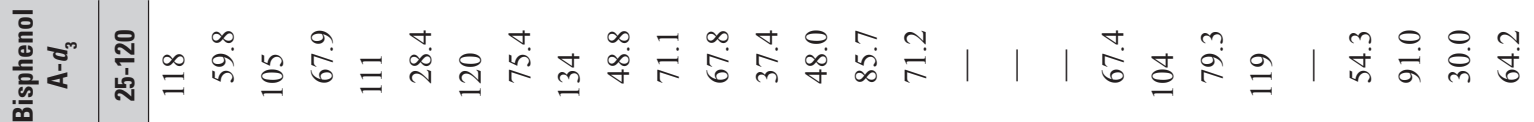

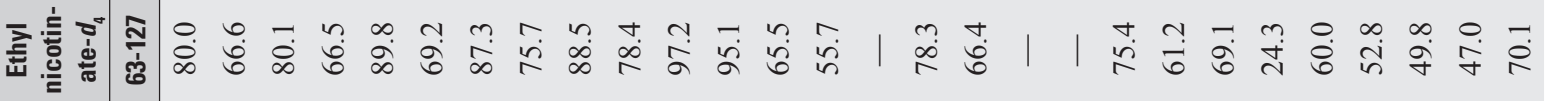

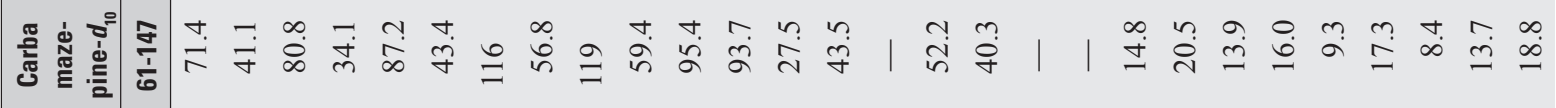

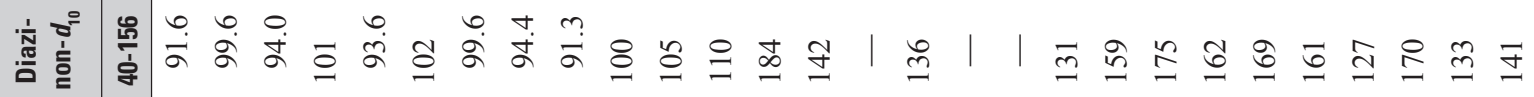

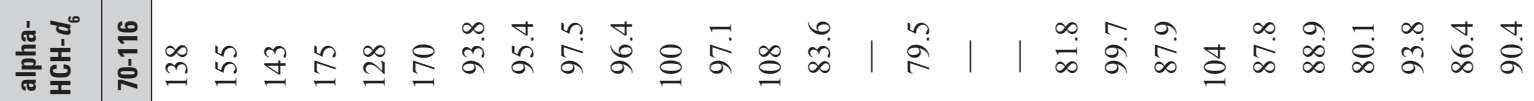

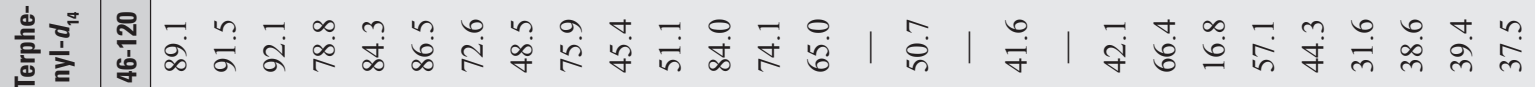

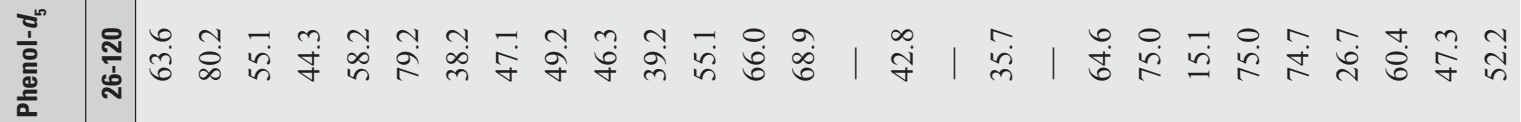

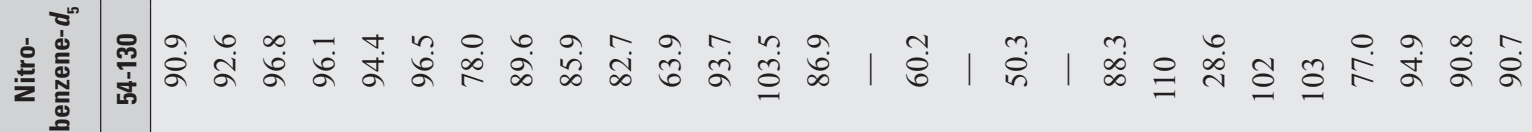

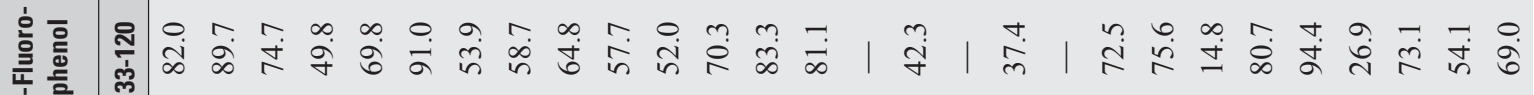
容

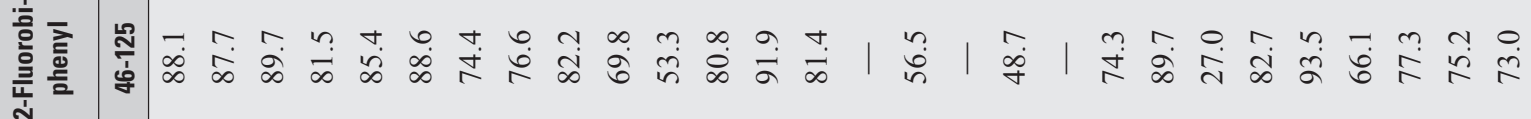

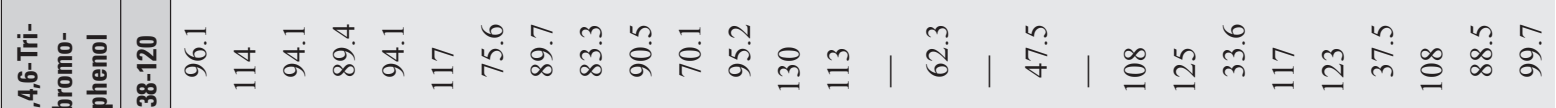

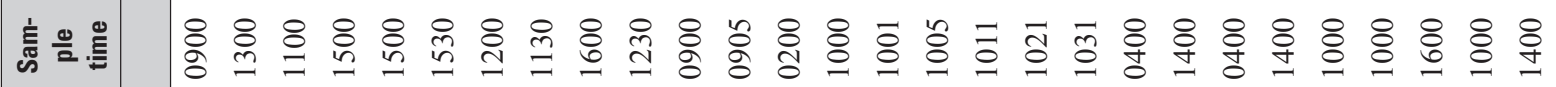

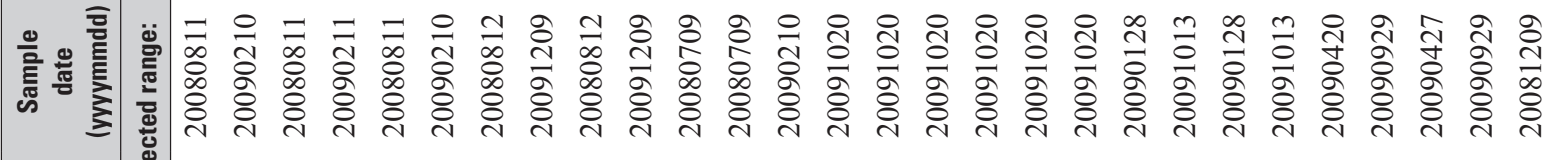

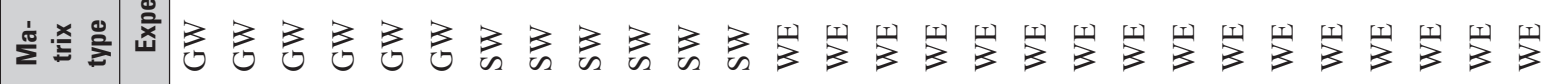

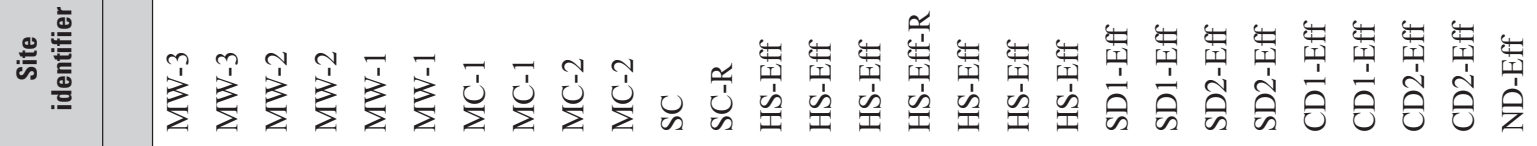




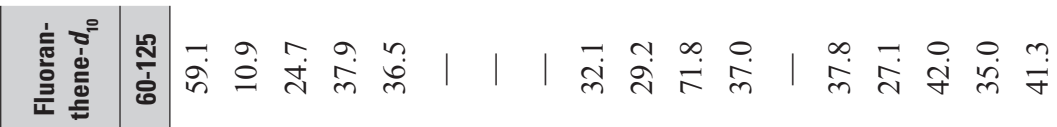

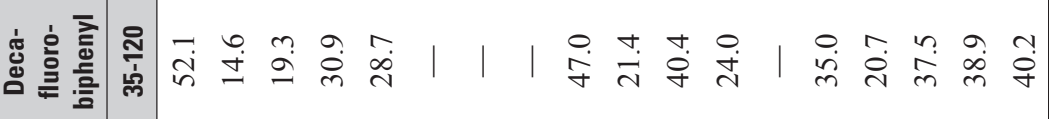
离

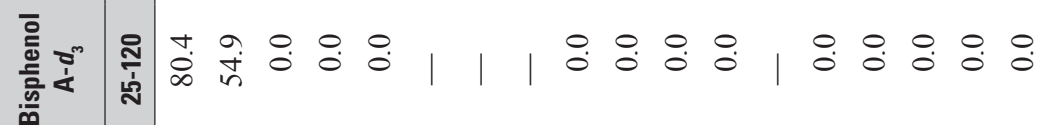

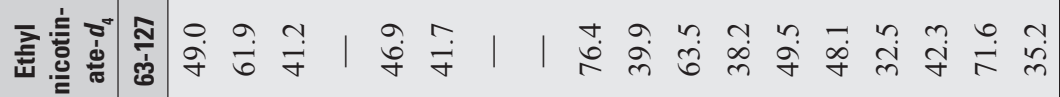

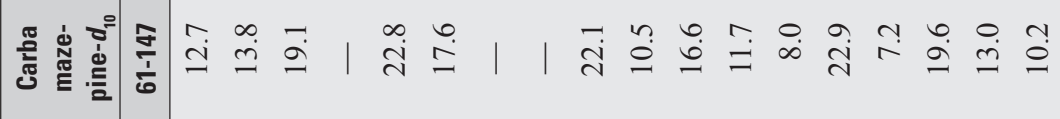

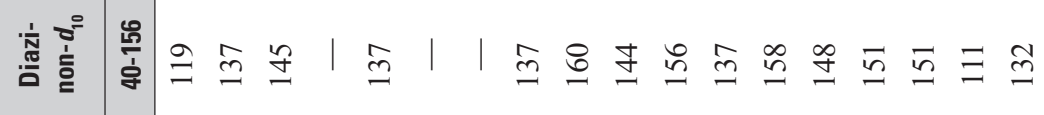

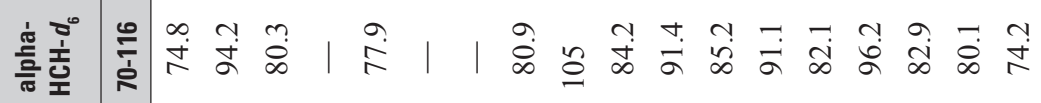
产竞

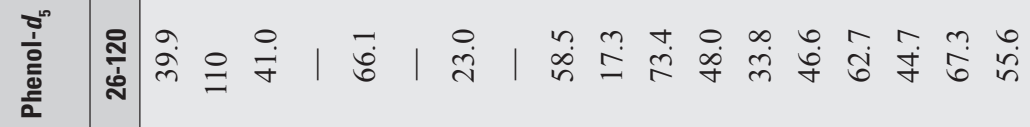
竧竞离

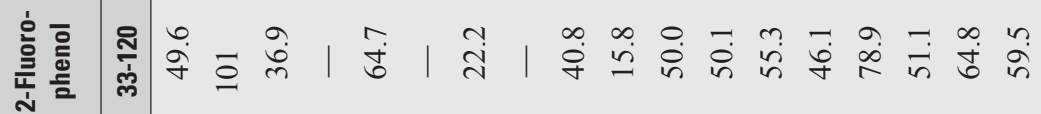
言高畜

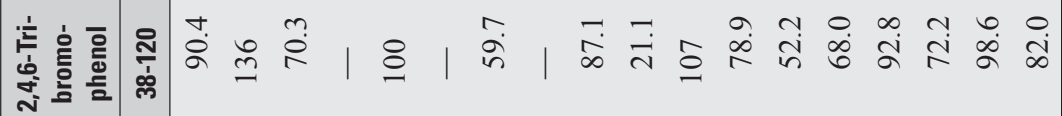

忘望

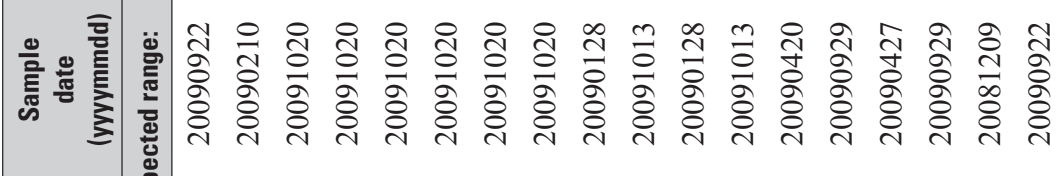

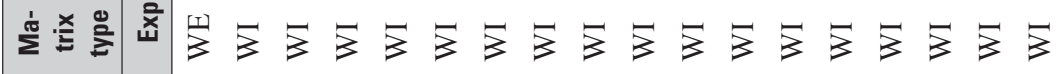
部言 
Manuscript approved on April 26, 2012

Publishing support provided by the Raleigh Publishing Service Center

For additional information, please contact: Director

Florida Water Science Center 10500 University Center Drive, Suite 215

Tampa, FL 33612-6427

(813) 498-5000

http://fl.water.usgs.gov/ 
